Gisele Accarino Martins Genofre

\title{
A inclusão social e laboral da pessoa deficiente
}

Dissertação de Mestrado

Orientador: Professor Doutor Ari Possidonio Beltran

Faculdade de Direito da Universidade de São Paulo 
Gisele Accarino Martins Genofre

\section{A inclusão social e laboral da pessoa deficiente}

Dissertação apresentada ao Departamento de Direito do Trabalho e da Seguridade Social da Faculdade de Direito da Universidade de São Paulo, como exigência parcial para a obtenção do título de Mestre em Direito do Trabalho, sob a orientação do Professor Doutor Ari Possidonio Beltran.

Faculdade de Direito da Universidade de São Paulo 


\title{
FOLHA DE APROVAÇÃO
}

Nome: GENOFRE, Gisele Accarino Martins.

Título: A inclusão social e laboral da pessoa deficiente.

\begin{abstract}
Dissertação apresentada ao Departamento de Direito do Trabalho e da Seguridade Social da Faculdade de Direito da Universidade de São Paulo, como exigência parcial para a obtenção do título de Mestre em Direito do Trabalho, sob a orientação do Professor Doutor Ari Possidonio Beltran.
\end{abstract}

Banca Examinadora 


\section{DEDICATÓRIA}

A Deus, por tudo.

Aos meus pais, Jarbas e Maria Antonia, fundamentais em minha formação, exemplo de carinho constante e apoio incondicional.

A minha irmã, Graziela, pelo eterno companheirismo.

A minha tia Conceição, sempre presente.

Ao meu companheiro, Rafael, pelo amor e compreensão, melhor incentivo que alguém pode ter.

Aos meus avôs e avós, Iolanda, Paschoal, Maria Tereza e Pedro (in memoriam). 


\section{AGRADECIMENTOS}

Agradeço imensamente ao Professor Ari Possidonio Beltran, pela orientação firme e serena e, sobretudo, pelo privilégio de merecer a sua confiança.

Agradeço aos demais professores do Departamento de Direito do Trabalho, pelos ensinamentos, e, em especial, aos Professores Nelson Mannrich, Ronaldo Lima dos Santos e Homero Batista Mateus da Silva.

Agradeço ao amigo e companheiro Eduardo Henrique Genofre, pelos anos em que convivemos juntos, pela ternura e apoio incondicional.

Agradeço às advogadas e amigas Cibelle Linero Goldfarb, Aline Moreira da Costa e Marina Santoro Franco Weinschenker, pelo incentivo e apoio constante.

Agradeço aos meus colegas de trabalho e aos advogados Walter Nimir, Gustavo Lorenzi de Castro e Andrea Pulici, pelo estímulo e aporte jurídico para a vida acadêmica.

Agradeço ao meu tio, João Grandino Rodas, pelas valiosas contribuições acadêmicas e exemplo de vida. 


\section{RESUMO}

A presente dissertação estuda a participação de pessoas com deficiências no mercado de trabalho. No primeiro capítulo, ventila-se a trajetória histórica da pessoa com deficiência desde a Idade Antiga até a Idade Contemporânea. A seguir, analisa-se a terminologia apropriada para denominar a pessoa que possui alguma forma de deficiência. No segundo capítulo, abordam-se as principais normas do Direito Internacional atinentes ao tema. A seguir, analisa-se o modo como a relação de emprego das pessoas com deficiência é abordada pelo Direito estrangeiro. No terceiro capítulo, discorre-se sobre a evolução do ordenamento jurídico brasileiro diante do tema, ponderando-se a aplicação da Constituição Federal e da Lei n. 8.213/91, bem como o papel do Ministério Público do Trabalho e do Ministério do Trabalho e Emprego e, ainda, os mecanismos e incentivos para o cumprimento da legislação. No quarto capítulo, são verificadas as peculiaridades do contrato de trabalho das pessoas com deficiência, analisando-se se a realidade brasileira observa os direitos assegurados pelas leis e pelo texto constitucional vigente, sopesando-se a existência de meios eficazes de fiscalização, incentivo e, até mesmo, exigência de contratação. Para a elaboração do presente estudo, utilizam-se os métodos indutivo - com a coleta de elementos para análise e elaboração do tema para posterior discussão e conclusão - , analítico-sintético - com o exame de textos jurídicos e não jurídicos - e comparativo - com a análise das características e da influência de diversas legislações nas condições de trabalho das pessoas com deficiência em momentos cronológicos distintos. São utilizadas a pesquisa bibliográfica e jurisprudencial, bem como a efetiva análise de textos legais.

Palavras-chave: Pessoas com deficiência. Relação de emprego. Contrato de trabalho. Direito comparado. 


\begin{abstract}
This dissertation studies the participation of people with disabilities in the labor market. The first chapter talks about the historical trajectory of people with disabilities, from the Ancient Age to the Contemporary Age. Next, we analyze the appropriate terminology to describe the person who has some form of disability. In the second chapter we discuss the main rules of international law relating to the theme. Next, we analyze how the ratio of employment of people with disabilities is addressed by foreign law. The third chapter discusses the evolution of Brazilian law on the subject, considering the application of the Constitution and the Law 8.213/91, as well as the role of the Public Ministry of Labor and the Ministry of Labor and Employment, and also the mechanisms and incentives for compliance. In the fourth chapter, we investigate the peculiarities of employment of people with disabilities by analyzing if the Brazilian reality observes the rights guaranteed by the Constitution and laws in force, weighing up the existence of effective means of enforcement, encouragement, and even hiring requirement. In this study, we use the inductive method - collecting elements for analysis and preparation of the issue for further discussion and conclusion - , analytic-synthetic method - examining legal and non-legal texts - , and comparative method - analyzing the characteristics and influence of various laws in working conditions of disabled people in different chronological moments. We searched the literature and jurisprudence, as well as the effective analysis of legal texts.
\end{abstract}

Keywords: People with disabilities. Employment relationship. Employment contract. Comparative law. 


\section{LISTA DE ILUSTRAÇÕES}

\section{MAPAS}

Quadro 1 - Estoque de pessoas com deficiência no mercado de trabalho, 2010 (CAGED, $2^{\circ}$ quadrimestre de 2011).

\section{GRÁFICOS}

Gráfico 1 - Distribuição dos municípios, por grupos de percentual de pessoas com pelo menos uma das deficiências investigadas na população residente, segundo Unidades da Federação (IBGE, Censo Demográfico 2010) 108

Gráfico 2 - Percentual de pessoas com pelo menos uma das deficiências investigadas na população residente, segundo os grupos de idade (IBGE, Censo Demográfico 2010) ...... 109 Gráfico 3 - Percentual de pessoas com pelo menos uma das deficiências investigadas na população residente, por sexo, segundo a cor ou raça (IBGE, Censo Demográfico 2010) 111 Gráfico 4 - Distribuição percentual da população de 15 anos ou mais de idade, por existência de pelo menos uma das deficiências investigadas e nível de instrução (IBGE, Censo Demográfico 2010) 113 Gráfico 5 - Taxa de atividade da população masculina de 10 anos ou mais de idade, por existência de pelo menos uma das deficiências investigadas, segundo os grupos de idade (IBGE, Censo Demográfico 2010).

Gráfico 6 - Taxa de atividade da população feminina de 10 anos ou mais de idade, por existência de pelo menos uma das deficiências investigadas, segundo os grupos de idade (IBGE, Censo Demográfico 2010) 115 Gráfico 7 - Taxa de atividade da população masculina de 10 anos ou mais de idade, por grupos de idade, segundo o tipo de deficiência investigada (IBGE, Censo Demográfico 2010)

Gráfico 8 - Taxa de atividade da população feminina de 10 anos ou mais de idade, por grupos de idade, segundo o tipo de deficiência investigada (IBGE, Censo Demográfico 2010). 117

Gráfico 9 - Nível de ocupação da população de 10 anos ou mais de idade, por sexo, segundo o tipo de deficiência investigada (IBGE, Censo Demográfico 2010). 118

Gráfico 10 - Distribuição das pessoas de 10 anos ou mais de idade, ocupadas na semana de referência, por existência de pelo menos uma das deficiências investigadas, segundo a posição na ocupação no trabalho principal (IBGE, Censo Demográfico 2010) .... 119 Gráfico 11 - Distribuição das pessoas de 10 anos ou mais de idade, ocupadas na semana de referência, por existência de pelo menos uma das deficiências investigadas, segundo aas classes de rendimento nominal mensal de todos os trabalhos (IBGE, Censo Demográfico 2010) 119

\section{QUADROS}

Quadro 1 - Estoque de pessoas com deficiência no mercado de trabalho, 2010 (CAGED, 2 ${ }^{\circ}$ quadrimestre de 2011). 


\section{LISTA DE TABELAS}

Tabela 1 - Distribuição percentual da população residente, por tipo de deficiência, segundo o sexo e os grupos de idade (IBGE, Censo Demográfico 2010) 110

Tabela 2 - Percentual de pessoas com pelo menos uma das deficiências investigadas na população residente, segunda as Grandes Regiões (IBGE, Censo Demográfico 2010) ....112 Tabela 3 - Distribuição percentual das pessoas de 15 anos ou mais de idade com pelo menos uma das deficiências investigadas, por nível de instrução, segundo as Grandes Regiões (IBGE, Censo Demográfico 2010). 114

Tabela 4 - Distribuição percentual das pessoas de 10 anos ou mais de idade, ocupadas na semana de referência, por condição de existência de deficiência, segundo as classes de rendimento nominal mensal de todos os trabalho (IBGE, Censo Demográfico 2010) ...... 120 


\section{SUMÁRIO}

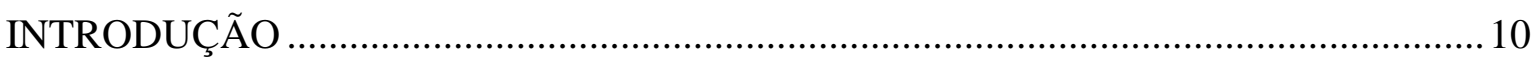

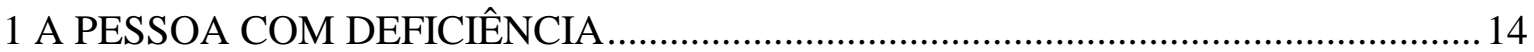

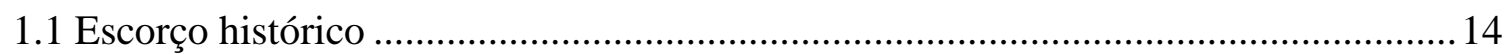

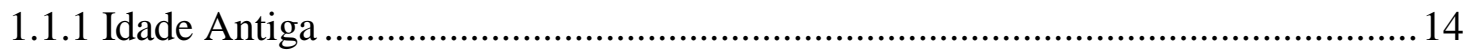

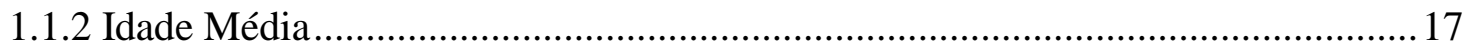

1.1.3 Idades Moderna e Contemporânea ..................................................................... 19

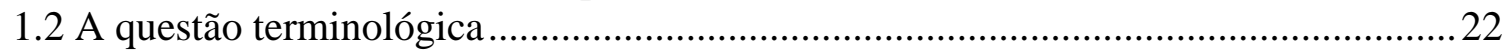

1.3 Abrangência do conceito de "pessoa com deficiência"................................................26

2 AS NORMAS DE PROTEÇÃO DA PESSOA COM DEFICIÊNCIA NO ÂMBITO INTERNACIONAL ……………………………………………………………. 31

2.1 Organização das Nações Unidas - ONU …………………………………………..... 31

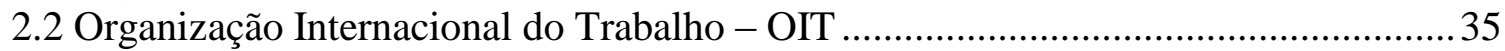

2.3 Organização dos Estados Americanos - OEA.......................................................... 42

2.4 União Europeia - UE ………………………………………………………....... 45

2.5 A normatização da relação de emprego da pessoa com deficiência no Direito

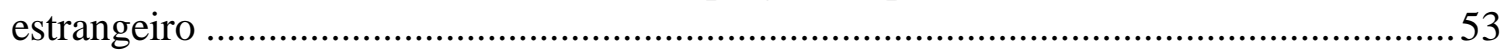

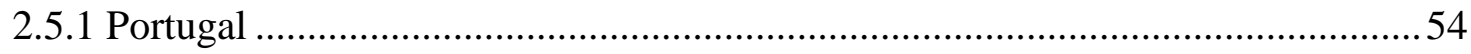

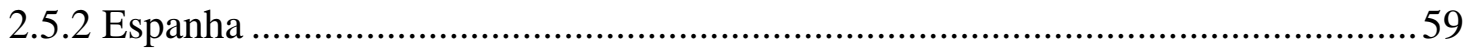

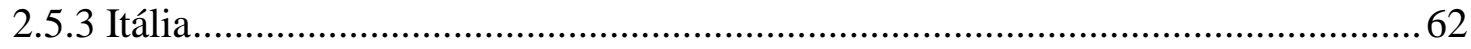

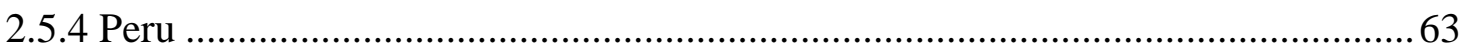

3 A EVOLUÇÃO DO ORDENAMENTO JURÍDICO BRASILEIRO: OS DIREITOS DA

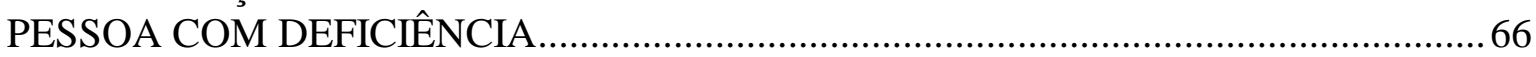

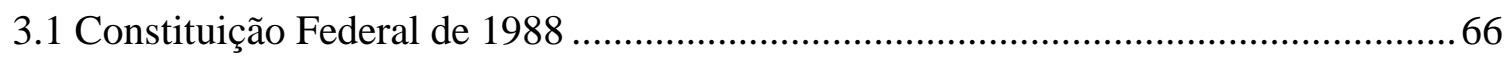

$3.2 \mathrm{O}$ princípio da igualdade e as ações afirmativas.........................................................76

3.3 Sistema legal de reserva de vagas ou sistema de cotas no Brasil: setor privado ..........80

3.3.1 Questões polêmicas acerca do Sistema Legal de Reserva de Vagas ...................... 86

3.3.2 A atuação do Ministério Público do Trabalho e do Ministério do Trabalho e

Emprego e os mecanismos de incentivo para cumprimento da legislação......................92

4 OS ASPECTOS DO CONTRATO DE TRABALHO DA PESSOA COM DEFICIÊNCIA

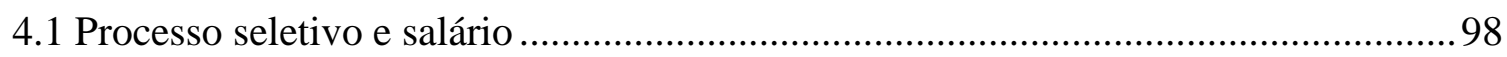

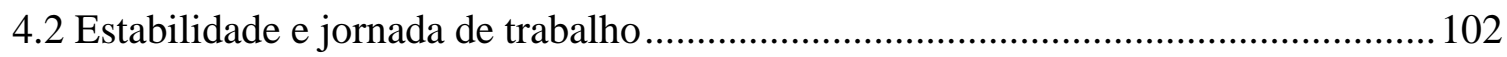

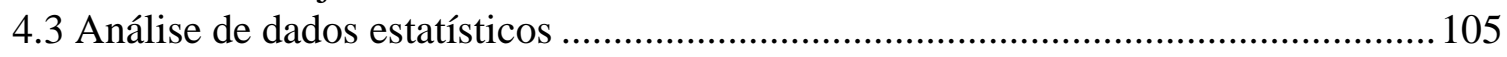

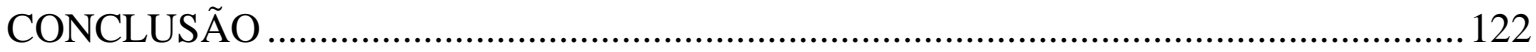

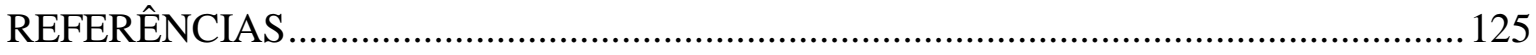




\section{INTRODUÇÃO}

De acordo com o Relatório Mundial sobre Deficiência, divulgado no dia 9 de junho de 2011 na sede da Organização das Nações Unidas (ONU) em Nova York (EUA), existe um número superior a 1 bilhão de pessoas em todo o mundo com algum tipo de deficiência. Referido documento foi elaborado pela Organização Mundial de Saúde (OMS) e pelo Banco Mundial, contando inclusive com a colaboração de mais 380 especialistas. Segundo o relatório, como resultado da exclusão social, as pessoas com deficiência têm menor qualidade na saúde, baixos avanços educacionais e menos oportunidades econômicas do que as pessoas sem deficiência. ${ }^{1}$

Assim, para traçar um panorama quantitativo, os resultados apresentados pelo Censo Demográfico 2000, realizado pelo Instituto Brasileiro de Geografia e Estatística (IBGE), declararam a existência de 24,6 milhões de pessoas que apresentavam algum tipo de deficiência no Brasil, correspondendo a $14,5 \%$ da população brasileira. ${ }^{2}$

E, ainda, apesar da divulgação parcial dos dados coletados, no Censo Demográfico 2010, realizado pelo mesmo instituto, foram declarados os percentuais da população brasileira que possui algum tipo de deficiência. Os resultados apontaram que 23,9\% da população brasileira possui alguma deficiência - aproximadamente 45 milhões de pessoas. $^{3}$

Diante deste exame inicial, é preciso ponderar que o Brasil possui uma significativa população de pessoas com deficiências, e, portanto, a participação destas pessoas no mercado de trabalho merece um estudo profundo. Inclusive quanto à real amplitude e grandeza da expressão "inclusão" através da atividade profissional, engrenagem primordial da dignidade humana.

\footnotetext{
${ }^{1}$ ORGANIZAÇÃO DAS NAÇÕES UNIDAS - ONU. Mais de um bilhão de pessoas no mundo têm algum tipo de deficiência, informa relatório da ONU. Disponível em: <http://onu.org.br/mais-de-um-bilhao-depessoas-no-mundo-tem-algum-tipo-de-deficiencia-informa-relatorio-da-onu>. Acesso em: 18 out. 2012.

${ }_{2}^{2}$ INSTITUTO BRASILEIRO DE GEOGRAFIA E ESTATÍSTICA - IBGE. Censo Demográfico 2000. Disponível em: <http://www.ibge.gov.br/home/presidencia/noticias/20122002censo.shtm>. Acesso em: 01 jun. 2011.

${ }^{3}$ INSTITUTO BRASILEIRO DE GEOGRAFIA E ESTATÍSTICA. Censo Demográfico 2010. Disponível em: 〈http://censo2010.ibge.gov.br/resultados〉. Acesso em: 18 out. 2012.
} 
Assim sendo, incluir socialmente um indivíduo com qualquer deficiência requer prioritariamente o afastamento do sentimento de piedade ou da elaboração de mecanismos isolados para atendimento desta categoria de pessoas. Incluir, ao revés, significa respeitar direitos e acolher a todos, sem quaisquer imposições de condições, possibilidades ou padrões. $^{4}$

Observa-se que a busca por uma sociedade inclusiva assume a necessidade de adequação de inúmeras divergências sociais e culturais, bem como modificações relevantes no ordenamento jurídico.

Nesta abordagem, para a elaboração do presente estudo será ventilada a trajetória histórica do deficiente desde a Idade Antiga até a Idade Contemporânea. Serão apontadas as referências mais significativas, ressaltada a evolução da inclusão da pessoa com deficiência na sociedade, e, ainda, elencadas as diferentes visões traçadas ao longo de muitas décadas.

Ato contínuo, buscar-se-á explicar e defender qual a terminologia mais apropriada para denominar a pessoa que possui alguma forma de deficiência. Sendo certo que o respeito ou a discriminação se fazem presentes inclusive na linguagem e na terminologia adotada, imperiosa uma abordagem particular quanto aos corretos termos a serem utilizados para indicar a pessoa com deficiência.

Diante da importância do tema em deslinde, tendo em vista os valores estatísticos anteriormente mencionados, cristalina a observância das normas de proteção ao deficiente no âmbito internacional. Nesta seara, serão suscitadas as normas de maior relevância e as considerações ventiladas pela Organização das Nações Unidas (ONU), pela Organização Internacional do Trabalho (OIT), pela Organização dos Estados Americanos (OEA), pela União Europeia, e, ainda, será abordado o modo como a relação de emprego das pessoas com deficiência é abordada pelo Direito estrangeiro, pontuando traços comparativos, com intuito único de possibilitar uma visão global sobre o tema.

\footnotetext{
${ }^{4}$ GABRILLI, Mara. Quem é deficiente: a cidade ou as pessoas que têm uma limitação física ou sensorial?
} 
Neste descortino, o presente trabalho busca discorrer sobre a evolução do ordenamento jurídico brasileiro diante do tema em tela, ponderando a aplicação objetiva da Carta Magna e da lei que dispõe sobre os benefícios da Previdência Social e sobre a inserção do sistema de cotas no setor privado (Lei n. 8.213/91), sendo ponderados também o papel, como órgão fiscalizador, do Ministério Público do Trabalho (MPT) e do Ministério do Trabalho e Emprego (MTE), e, ainda, sopesando quais seriam os mecanismos e incentivos de cumprimento da legislação. Dentro deste exame, será traçada inclusive uma abordagem ampla sobre as ações afirmativas e suas peculiaridades, em especial no Brasil.

Nesta seara, buscar-se-á uma interpretação ampla da legislação vigente, no tocante à inclusão de pessoas ou "padrões" não contemplados na Lei n. 8.213/91 e no Decreto n. 3.298/99 para fins de preenchimento de cotas, como, por exemplo, pessoas queimadas, com surdez unilateral, visão monocular, lábio leporino e/ou fenda palatina, diabéticas insulino-dependentes, ex-cancerosas e obesas.

Nota-se que a Lei de Cotas não prevê a inclusão dessa "deficiência invisível”, mas a exclusão no mercado de trabalho desta parcela da população é notória, sendo certo que encontram inúmeras dificuldades nos processos regulares de seleção.

A esse propósito, visa-se verificar as peculiaridades do contrato de trabalho das pessoas com deficiência no intuito de analisar se a realidade brasileira observa os direitos assegurados pelas leis e pelo texto constitucional vigente, sopesando a existência de meios eficazes de fiscalização, incentivo e, até mesmo, exigência de contratação.

Para a elaboração do presente estudo, será utilizado o método indutivo, posto que primeiramente será demandada toda a coleta de elementos fundamentais para análise e elaboração do tema, para posterior discussão e conclusão. Utilizar-se-á o método analíticosintético de pesquisa, examinando-se textos jurídicos e não jurídicos, tratando-se detalhadamente sobre as questões pertinentes ao tema.

Revista do Advogado. São Paulo, n. 95, p. 92-97, dez. 2007, p. 92. 
Assim sendo, para possibilitar uma visão ampla sobre o tema, será observado o método comparativo, tendo em vista a análise das características e a influência de diversas legislações no tocante às condições de trabalho das pessoas com deficiência em momentos cronológicos distintos.

Por derradeiro, o instrumento de investigação a ser utilizado será a pesquisa bibliográfica e jurisprudencial, bem como a efetiva análise do texto constitucional, das leis brasileiras, de declarações e convenções internacionais e, ainda, a verificação de projetos de lei em trâmite no Brasil. 


\section{A PESSOA COM DEFICIÊNCIA}

\subsection{Escorço histórico}

As anomalias físicas ou mentais, as deformações congênitas, as amputações decorrentes de traumas e, ainda, as doenças graves com consequências incapacitantes, são parte integrante da própria história da humanidade, em razão de sua antiguidade. ${ }^{5}$

De fato, em algum momento histórico durante a trajetória humana, restou necessária uma análise pontual quanto aos indivíduos mais fracos ou com uma suposta diminuição de utilidade na força de trabalho. Assim sendo, foram elencados primeiramente os idosos, as crianças e os acometidos de alguma doença física ou mental ou vítimas de acidentes indivíduos que geravam inúmeros desafios e "prejuízos” para o desenvolvimento do convívio social.

$\mathrm{O}$ respeito adquirido, o reconhecimento de direitos e o espaço conquistado atualmente pelas pessoas com deficiências são fruto de um longo e penoso processo de transformação.

Por essa razão, se faz necessário um levantamento histórico para melhor entendimento das atitudes e preocupações cotidianas e atuais da sociedade frente às deficiências culturais e sociais enfrentadas no passado.

\subsubsection{Idade Antiga}

Na época primitiva, a busca por alimento era uma questão de sobrevivência. A caça era a principal fonte de alimento naquele momento histórico, sendo certo que a boa capacidade física era fator primordial para a manutenção da vida.

Observavam-se, naquele contexto, claramente dois tipos de atitudes com relação às

\footnotetext{
${ }^{5}$ SILVA, Otto Marques da. A epopéia ignorada: a pessoa deficiente na história do mundo de ontem e de hoje. São Paulo: Cedas, 1987, p. 21.
} 
pessoas deficientes, a primeira de eliminação, menosprezo e destruição, e, a segunda, de tolerância e aceitação. ${ }^{6}$

A história caminhava no sentido de que cada povo ou cada tribo, em razão das inúmeras experiências acumuladas e observações do cotidiano, desenvolvia seus próprios regramentos. Assim sendo, não existia um padrão utilizado por todos os povos, alguns praticavam o extermínio dos deficientes físicos quando do nascimento destes ou ao longo de suas vidas. Outros povos, em contrapartida, consideravam o deficiente físico um membro comum do grupo ou até mesmo um enviado dos deuses para beneficiar a tribo. ${ }^{7}$

Com relação aos povos primitivos que adotaram atitudes de apoio ou aceitação para com os deficientes, Otto Marques da Silva elenca com propriedade algumas tribos, a saber:

\begin{abstract}
Ashanti - Habitam a parte sul de Gana, a oeste da África, totalizando mais de um milhão de membros. Quando constituíam um reino próprio era costumeiro enviar à corte crianças com defeitos físicos para serem treinadas como arautos do rei. Esses mensageiros com deficiência física eram destacados para missões delicadas, como, por exemplo, a iminência de guerras com tribos vizinhas. Em geral a mensagem do rei Ashanti era incisiva e terminava com um recado do arauto: "se esses termos não forem aceitos, poderei ser morto agora mesmo". No entanto, parece que isso não acontecia, pois limitavam-se os inimigos a cortar um dos dedos do arauto, o que equivalia a uma declaração de guerra. Além dessa perigosa missão, os arautos eram também utilizados como inspetores sanitários ou coletores de impostos. Eram igualmente usados como bufões e tinham o privilégio de dizer a seus mestres o que bem entendiam. Foram também usados como espiões.

$[\ldots]$

Semang - Entre os nativos da raça Semang, habitantes de parte da Malásia, só pessoas que se movem com o auxílio de um bastão ou de uma muleta, devido a um defeito físico ou cegueira, é que são procuradas para conselhos ou para decidir disputas. Trata-se de uma tribo Negrito, muito primitiva, que ainda vive em cavernas ou em abrigos de folhas. ${ }^{8}$
\end{abstract}

Infelizmente, a grande maioria dos povos primitivos vislumbrava no extermínio uma solução para os problemas das pessoas com deficiências físicas ou mentais. Confirmando referidas práticas o autor destaca:

\footnotetext{
${ }^{6}$ SILVA, Otto Marques da. Op. cit., p. 39.

${ }^{7}$ ALVES, Rubens Valtecides. Deficiente físico: novas dimensões da proteção ao trabalhador. São Paulo: LTr, 1992, p. 18.

${ }^{8}$ SILVA, Otto Marques da. Op. cit., p. 40-41.
} 
Jukun - Trata-se de uma tribo da Nigéria, na qual as crianças que nascem com deformações não sobrevivem. Elas são abandonadas nas matas ou nos lugares ermos onde logo encontram a morte. Acreditam os nativos Jukun que as crianças com defeitos físicos são tomadas, ainda no ventre da mãe, por espíritos malignos.

[...]

Sálvia - Nas matas fechadas da selva amazônica vivem os índios Sálvia, em extinção. Eles costumam dar a morte aos fisicamente deficientes por serem considerados como elementos claramente marcados por espíritos malignos. ${ }^{9}$

Destaca-se, ainda, que o povo asteca, na época de Montezuma, separava homens e mulheres com deformidades ou com diferenças de um suposto "padrão", como anões ou pessoas albinas, colocando-os em uma espécie de circo, ridicularizando e provocando esses indivíduos publicamente. ${ }^{10}$

De acordo com o posicionamento e ensinamentos dos médicos do Antigo Egito, as doenças graves, as deficiências físicas e os problemas mentais graves eram provocados por maus espíritos, por demônios ou por pecados de vidas anteriores. Assim sendo, somente por meio da força divina passada aos médicos-sacerdotes os males poderiam ser sanados. ${ }^{11}$

Os hebreus demonstravam um tratamento claramente discriminatório em seus textos de leis vigentes, sendo certo que pessoas com deficiências físicas ou mentais ou com qualquer forma de anormalidade eram considerados impuros ou pecadores. ${ }^{12}$

Em Atenas e em Esparta algumas determinações oficiais concediam aos soldados feridos e seus familiares vantagens de diversas naturezas. Eram observadas condições diferenciadas quanto à alimentação, sendo certo que cumpria ao Estado o sustento dessa categoria de pessoas. ${ }^{13}$

Ratificando o quanto informado, alguns personagens desse momento histórico abordaram os dilemas da pessoa com deficiência, com absoluta sabedoria. Neste sentido,

\footnotetext{
${ }^{9}$ SILVA, Otto Marques da. Op. cit., p. 44-45.

${ }^{10}$ Ibidem, p. 46.

${ }^{11}$ Ibidem, p. 56.

12 ALVES, Rubens Vatecides. Op. cit., p. 20.
} 
Aristóteles determinou aos membros do Conselho Ateniense:

O Conselho passará agora a examinar o problema dos deficientes. Existe, de fato, uma lei que estabelece que todo ateniense cujos bens não ultrapassem três minás e cujo corpo esteja mutilado ao ponto de não lhe permitir qualquer trabalho seja examinado pelo Conselho e que seja concedido a cada um deles, às expendas do estado, dois óbulos por dia para sua alimentação. E existe um tesoureiro dos deficientes, designado para tal. ${ }^{14}$

Nesta mesma linha, e com a inclinação de valorizar atitudes sociais de integração, Aristóteles indicava "ser mais fácil ensinar a um aleijado a desempenhar uma tarefa útil do que sustentá-lo como indigente". ${ }^{15}$

Alexandre, o Grande, também marcou sua trajetória ao apreciar os esforços trilhados por seus soldados. Assim sendo, um ano antes de sua morte encaminhou de volta à Macedônia os inválidos e aqueles que tivessem perdido algum membro na guerra. Determinou, ainda, que em todas as assembleias de jogos e divertimentos públicos estes fossem preferidos e que ficassem nos melhores lugares e coroados de flores. ${ }^{16}$

Conforme análise histórica, observa-se uma imensa parcela de características e subsídios deixados pela Idade Antiga com relação às atividades sociais e às peculiaridades da pessoa com deficiência.

Dentro dessa realidade, o conteúdo histórico encontrado é abundante e com vastos personagens marcantes; todavia, procurou-se destacar somente algumas passagens desse período para melhor entendimento da evolução do tema em debate.

\subsubsection{Idade Média}

O advento do cristianismo e o conteúdo da doutrina cristã pregava a caridade, o amor ao próximo e a humildade do ser humano. Nesta seara, aqueles que seguiam os

\footnotetext{
${ }^{13}$ SILVA, Otto Marques da. Op. cit., p. 98.

${ }^{14}$ Ibidem, p. 99.

${ }^{15}$ Ibidem, p. 97.

${ }^{16}$ Ibidem, p. 113.
} 
preceitos da religião buscavam de certa forma entender as necessidades do próximo, o que englobava entender as necessidades das pessoas com deficiências.

Embora o cristianismo seja observado como um meio facilitador das conquistas dos deficientes, muitos reagiam de forma agressiva e contrária aos preceitos cristãos, sendo certo que a evolução social e cultural perseguida caminhava vagarosamente.

Paulatinamente, observou-se que os casos de doenças graves e as considerações quanto às pessoas com deficiências físicas e mentais passaram a receber atenção diferenciada, o que pode ser percebido através do crescente desenvolvimento dos hospitais e ambientes para tratamento da saúde.

Na parte leste da Europa, hospitais e abrigos para pessoas pobres e com deficiências eram criados por senhores feudais ou através de governantes de aglomerados urbanos, sempre com a colaboração e iniciativa de segmentos da Igreja Católica. ${ }^{17}$

Segundo documentos históricos, no Japão, durante a Idade Média, a profissão de massagista e as técnicas de acupuntura eram exercidas quase que exclusivamente por pessoas cegas. Esse privilégio foi garantido em razão da influência do filho do imperador japonês, o príncipe Hitoyasu, que havia perdido a visão. Neste sentido, o imperador intercedeu em favor dos deficientes visuais, promovendo oportunidades para aqueles que buscavam desenvolver uma atividade profissional. ${ }^{18}$

A “Lei dos Pobres", editada na Inglaterra em 1531, é um exemplo cristalino de uma norma que infelizmente não atingiu sucesso no sentido de aprimorar ou favorecer as condições de trabalho dos deficientes. Referida lei autorizava inicialmente que os juízes concedessem licenças para que pessoas idosas ou com defeitos físicos graves pudessem pedir esmolas. ${ }^{19}$

\footnotetext{
${ }^{17}$ SILVA, Otto Marques da. Op. cit., p. 198.

${ }^{18}$ Ibidem, p. 204.

${ }^{19}$ MELO, Sandro Nahmias. O direito ao trabalho da pessoa portadora de deficiência: ação afirmativa, o princípio constitucional da igualdade. São Paulo: LTr, 2004, p. 34.
} 
Ato contínuo, em 1723 referida norma foi modificada, autorizando cada paróquia a construir casas de trabalho ou oficinas denominadas workhouses — para participação dos pobres e das pessoas com deficiências — podendo, inclusive, recusar trabalho para aqueles que delas não participassem. O objetivo original da "Lei dos Pobres" merece ser exaltado; entretanto, nenhuma das alterações normativas alcançou os efeitos almejados, tendo em vista que as pessoas pobres eram vistas com prioridades quando comparadas com os deficientes. $^{20}$

Por derradeiro, cumpre ponderar que o advento do "Renascimento" trouxe um grande avanço na área das ciências, proporcionando paralelamente uma visão mais humanitária, em especial com relação às pessoas com deficiências. As obras e pinturas da época também refletiam mudanças sociais significativas, deixando patente um ideal de afastamento das atitudes inadequadas da sociedade. Tais circunstâncias influenciaram na adequação de normas legais com o intuito de resguardar as pessoas com deficiências ou em condições limitantes. ${ }^{21}$

\subsubsection{Idades Moderna e Contemporânea}

O avanço na área das ciências proporcionou inúmeras mudanças no comportamento das sociedades. Nota-se, neste período histórico, uma visão modificada, inclusive no plano jurídico, no tocante às condições das pessoas com deficiências.

$\mathrm{Na}$ Europa, muitas barreiras puderam ser superadas frente aos notáveis inventos capazes de amenizar algumas das dificuldades enfrentadas pelos deficientes. Cumpre destacar alguns exemplos, como a criação da cadeira de rodas, o uso de bengalas ou bastões de apoio, muletas, próteses, entre outros benefícios, todos inventados a partir do século XIX. ${ }^{22}$

Desta forma, destaca-se que durante o século XIX foram observados incontáveis avanços no campo da medicina, dentre os quais imperioso citar a criação, no ano de 1825 ,

\footnotetext{
${ }^{20}$ SILVA, Otto Marques da. Op. cit., p. 258.

${ }^{21}$ ALVES, Rubens Vatecides. Op. cit., p. 26.

${ }^{22}$ Ibidem, p. 26.
} 
do método de leitura Braille, pelo professor Louis Braille, favorecendo o uso da leitura e da escrita pelos deficientes visuais, e, ainda, os relevantes avanços na área da ortopedia. ${ }^{23}$

Ainda durante o mesmo século, um marco importante deve ser lembrado, qual seja, o surgimento da "Revolução Industrial". Neste contexto, o progresso das fábricas nas cidades despertou um grande interesse na população rural, sendo certo que a busca por melhores condições de trabalho fez crescer de forma alarmante o labor nos centros urbanos.

Com efeito, neste momento histórico, a utilização indiscriminada da mão de obra infantil e feminina ganha espaço e força nas relações de trabalho, bem como a permanência no labor durante longos períodos. De fato, condições indignas de trabalho tornaram-se causas diretas de inúmeras mortes e acidentes relacionados à atividade industrial. ${ }^{24}$

Ato contínuo, as deficiências físicas em específico, que no passado foram observadas tão somente como um problema de nascença, reflexos de batalhas ou decorrentes de acidentes domésticos, passaram a integrar também o ambiente de trabalho, em razão da nova forma de produção das fábricas e das atividades profissionais exercidas.

Neste contexto, resta claro o surgimento das doenças profissionais e das deficiências decorrentes de acidentes de trabalho.

Assim sendo, em 1883 Otto von Bismark voltou seu olhar para as questões relacionadas à proteção dos acidentados no trabalho. Criou-se uma legislação para proteger, assegurar e readaptar, através de programas de recuperação, o trabalhador prejudicado em razão de um acidente de trabalho. ${ }^{25}$ Referida providência provocou reflexos em diversos países da Europa, sendo certo que as próprias seguradoras incentivavam o retorno ao trabalho.

\footnotetext{
${ }^{23}$ GOLDFARB, Cibelle Linero. Pessoas portadoras de deficiência e a relação de emprego: o sistema de cotas no Brasil. Curitiba: Juruá, 2008, p. 27.

${ }^{24}$ BOUCINHAS FILHO, Jorge Cavalcanti. Ações afirmativas e inserção de pessoas portadoras de deficiência no mercado de trabalho. Revista da Faculdade de Direito Universidade de São Paulo. São Paulo, v. 100, p. 493-523, jan./dez. 2005, p. 498.

${ }^{25}$ GOLDFARB, Cibelle Linero. Op. cit., p. 28.
} 
Ademais, observou-se, no século XX, um incremento significativo no tocante à assistência às pessoas com deficiências, em especial através da criação de organizações e entidades voltadas para os interesses dessa categoria.

Cumpre destacar, ainda, que o elevado número de pessoas doentes e mutiladas no período pós-guerra exigia providências e soluções práticas para a reintegração destas à sociedade. Nesse desenvolvimento, mostrou-se uma melhora considerável no sistema de bem-estar social, assistência pública e promoção social, todos estes atrelados ao avanço acelerado da medicina e à implantação de sistemas de tratamento de água e esgoto, proporcionando sobremaneira uma conquista positiva na qualidade de vida e nas condições para o progresso do homem. ${ }^{26}$

Diante desse panorama, existia de forma nítida um contingente infinito de problemas gerados pelas guerras e o aumento substancial de doentes e mutilados vítimas do abandono social, e, por outra esteira, vislumbrava-se o avanço da tecnologia e o progresso da medicina em diversas áreas.

Todavia, apesar dos avanços verificados, não se pode apagar que, durante o século XX, o ditador alemão Adolf Hitler, na busca de uma suposta "pureza de raças", procedeu ao extermínio de milhares de pessoas com deficiência mental, ${ }^{27}$ e, ainda, que a província chinesa de Gansu legalizou a esterilização de deficientes mentais, ${ }^{28}$ o que comprova a existência de estruturas sociais merecedoras de profundo estudo e atenção.

Infelizmente, apesar de tantos avanços e retrocessos, é possível perceber no século XXI que a inclusão de pessoas com deficiências na sociedade, e principalmente no mercado de trabalho, ainda é precária e carecedora de eficácia plena. Os preconceitos não foram superados, tão somente variaram ao longo de tantos anos na história do mundo.

\footnotetext{
${ }^{26}$ SILVA, Otto Marques da. Op. cit., p. 302.

${ }^{27}$ GOLDFARB, Cibelle Linero. Op. cit., p. 29.

${ }^{28}$ MELO, Sandro Nahmias. Op. cit., p. 38.
} 


\subsection{A questão terminológica}

Precipuamente, destaca-se que a sociedade, a doutrina, bem como a própria legislação vigente utilizam terminologias distintas para tratar e conceituar as pessoas com deficiências. Assim sendo, para delimitar e escolher a expressão mais adequada, necessário atentar para a correta conotação utilizada.

Ocorre que, no passado, inúmeras expressões foram utilizadas de forma pejorativa para apontar um deficiente, destacando tão somente a existência da doença e afastando a individualidade do homem e sua dignidade, como, por exemplo, "aleijado", "maneta", “manco", “mongoloide”, “defeituoso", "mudinho", entre outros.

Expressões como "acometido por deficiência", "pessoa fisicamente diminuída" e “incapaz" valorizam tão somente os aspectos excludentes da deficiência, negando e afastando os direitos do indivíduo. ${ }^{29}$

$\mathrm{O}$ respeito ou a discriminação se faz presente inclusive na linguagem e na terminologia adotada. Assim sendo, necessária uma abordagem particular quanto aos corretos termos a serem utilizados para indicar a pessoa com deficiência.

Nesta seara, deve-se abandonar e afastar toda a linguagem contundente e inadequada utilizada nos tempos pretéritos, onde predominavam o preconceito e a ausência de consciência social.

Observa-se com absoluta cautela que, segundo a visão de alguns autores, a expressão "deficiente" seria utilizada para relacionar o oposto daquilo que é eficiente, e, ainda, que o termo "descapacitado" refletiria a ausência de capacidade. Referidas terminologias são utilizadas no Brasil e em outros países, como por exemplo a Espanha, que utiliza a expressão discapacitados ou personas con minusvalía, e os Estados Unidos da América, que correntemente fazem uso da denominação disabilities. ${ }^{30}$

${ }^{29}$ FONSECA, Ricardo Tadeu Marques da. O trabalho da pessoa com deficiência e a lapidação dos direitos humanos: o direito do trabalho, uma ação afirmativa. São Paulo: LTr, 2006, p. 101.

30 BERVENVANÇO, Rosana Beraldi. Direitos da pessoa portadora de deficiência: da exclusão à 
De acordo com os ensinamentos de Antonio Herman de Vasconcelos, "muitos argumentam, com razão, que o termo deficiente mais serve para ressaltar as diferenças do indivíduo do que suas similaridades com o chamado grupo normal."31

Ocioso ponderar, segundo os ensinamentos de Eugênia Augusta Gonzaga Fávero:

a palavra deficiente não deveria gerar esse reflexo negativo, pois deficiência não é o contrário de eficiência. O contrário de eficiência é ineficiência. Especialmente quando se refere a seres humanos, a deficiência não deve ser traduzida como imperfeição ou defeito, já que não existe perfeição ou ausência total de defeitos em qualquer ser humano, ou seja, não se pode dizer que pessoas sem deficiência são pessoas... perfeitas. A deficiência, neste caso, indica falta, limitação. ${ }^{32}$

Respeitando cada um dos posicionamentos mencionados, entende-se que o termo "deficiente" seria utilizado para destacar tão somente as diferenças da pessoa, sem ventilar suas igualdades com todo e qualquer indivíduo.

Portanto, alguns doutrinadores acolhem a expressão "pessoas portadoras de necessidades especiais" como sendo apropriada. Seguindo esta linha, referida nomenclatura seria utilizada para acolher um grande número de situações que envolvem anomalias físicas, mentais e fisiológicas. ${ }^{33}$ Destacando-se, inclusive, que o adjetivo utilizado não poderia se sobrepor ao substantivo que identifica a condição humana: pessoa. ${ }^{34}$

Perfilhando em sentido oposto, observam-se na doutrina pensamentos adversos quanto ao uso da expressão "pessoas portadoras de necessidades especiais", ao passo que alguns entendem que qualquer indivíduo, ainda que de forma temporária, pode portar alguma necessidade especial, sem, contudo, vislumbrar-se inserido nas normas legais

igualdade. Curitiba: Ministério Público do Estado do Paraná, 2001, p. 10-11.

${ }^{31}$ BENJAMIN, Antonio Herman de Vasconcelos e. A tutela das pessoas portadoras de deficiência pelo Ministério Público. Direitos da pessoa portadora de deficiência. Revista da Advocacia Pública \& Sociedade. São Paulo, ano 1, n. 1, p. 13-38, 1997, p. 15.

${ }^{32}$ FÁVERO, Eugênia Augusta Gonzaga. Direitos das pessoas com deficiência: garantia de igualdade na diversidade. Rio de Janeiro: WVA, 2004, p. 23-24.

${ }^{33}$ BOLONHINI JUNIOR, Roberto. Portadores de necessidades especiais: as principais prerrogativas dos portadores de necessidades especiais e a legislação brasileira. São Paulo: Arx, 2004, p. 18.

${ }^{34}$ MELO, Sandro Nahmias. Op. cit., p. 43. 
protetivas. Destaca-se como exemplo um acidentado que tem sua capacidade de locomoção reduzida temporariamente ou uma pessoa superdotada que possui necessidades especiais, mas não tem obrigatoriamente uma deficiência. Neste descortino, um portador de deficiência seria um portador de necessidade especial, mas o inverso não necessariamente seria aplicável. ${ }^{35}$

Percebe-se uma relevante amplitude na expressão "pessoas com necessidades especiais", tendo em vista tratar-se de um gênero onde foram inseridas as pessoas com deficiência, mas também os idosos, as gestantes ou qualquer pessoa em situação que implique um tratamento diferenciado. ${ }^{36}$

Quanto à questão terminológica, alguns autores ${ }^{37}$ e a própria Constituição Federal fazem uso da expressão "pessoa portadora de deficiência". Especialmente neste contexto, necessário destacar que o termo "deficiência" carrega um pensamento de falta, carência ou ausência. Assim sendo, deve ser observada com cuidado a união dos termos "portador" e "deficiência", tendo em vista a possibilidade de causar um descompasso semântico na terminologia adotada.

Ainda, sopesando o conceito de "pessoa portadora de deficiência", é possível observar os ensinamentos do doutrinador Ricardo Tadeu Marques da Fonseca, que entende que as deficiências não se portam, estão com a pessoa ou na pessoa. ${ }^{38}$

Nota-se que a Carta Magna, assim como diversas leis posteriores, buscou afastar as terminologias utilizadas no passado com conotação negativa, como, por exemplo, inválido, surdo-mudo, aleijado, retardado, entre outras expressões. O legislador buscou naquele momento histórico, através do uso da expressão "pessoa portadora de deficiência", uma padronização terminológica que afastasse a atenção da deficiência e enfatizasse o

\footnotetext{
35 RULLI NETO, Antonio. Direitos do portador de necessidades especiais: guia para o portador de deficiência e para o profissional do Direito. 2. ed., São Paulo: Fiúza Editores, 2002, p. 32.

${ }^{36}$ BRASIL. Ministério do Trabalho e Emprego. A inclusão das pessoas com deficiência no mercado de trabalho. Brasília, 2007. Disponível em: <http://www.acessibilidade.org.br/cartilha_trabalho.pdf>. Acesso em 13 jan. 2013, p. 20.

${ }^{37}$ BERVENVANÇO, Rosana Beraldi. Op. cit., p. 12.

${ }^{38}$ FONSECA, Ricardo Tadeu Marques da. O trabalho da pessoa com deficiência... Op. cit., p. 270.
} 
indivíduo, todavia o foco alcançou tão somente o portador, não chegando à pessoa. ${ }^{39}$

Com efeito, "pessoa portadora de deficiência" e "pessoa portadora de necessidades especiais" são exemplos de terminologias que não caracterizam com exatidão a condição do indivíduo.

Segundo orientações traçadas pela Secretaria dos Direitos da Pessoa com Deficiência do Governo do Estado de São Paulo, a terminologia adequada seria "pessoa com deficiência", esclarecendo-se, ainda, que o termo "portador de deficiência" e suas flexões no feminino e no plural devem ser afastados, porque a deficiência não pode ser entendida como coisas que às vezes portamos e às vezes não portamos. ${ }^{40}$

A partir deste pensamento, muitos autores ${ }^{41}$ entendem que o termo "pessoa com deficiência" seria o mais apropriado, tendo em vista que a expressão "portador" traria uma conotação negativa associada a doença, ${ }^{42}$ sendo aquela utilizada inclusive em inúmeros instrumentos internacionais, como por exemplo a Convenção sobre os Direitos das Pessoas com Deficiência (Decreto n. 6.949 de 25 de agosto de 2009). ${ }^{43}$

Como observa Antonio Rulli Neto, "um primeiro passo na integração do indivíduo à sociedade seria deixar de caracterizá-lo como diferente e deficiente, mas como igual a todos, com algumas necessidades diferentes daquelas que as demais pessoas têm". ${ }^{4}$

Afastar as barreiras impostas quanto à maneira de se referir ao deficiente sugere uma maior legitimidade para a categoria e uma conquista contra o fantasma da discriminação.

\footnotetext{
${ }^{39}$ FÁVERO, Eugênia Augusta Gonzaga. Op. cit., p. 21.

${ }^{40}$ SASSAKI, Romeu Kazumi. Terminologia: sobre a deficiência na era da inclusão. Disponível em: <http:// www.pessoacomdeficiencia.sp.gov.br/portal.php/informacoes/terminologia>. Acesso em: 18 jun. 2011.

${ }^{41}$ FONSECA, Ricardo Tadeu Marques da. $\mathbf{O}$ trabalho da pessoa com deficiência... Op. cit., p. 270.

${ }^{42}$ FÁVERO, Eugênia Augusta Gonzaga. Op. cit., p. 22.

43 BRASIL. Decreto n. 6.949, de 25 de agosto de 2009. Disponível em: <http://www.planalto.gov.br/ccivil_03/_ato2007-2010/2009/decreto/d6949.htm>. Acesso em: 25 jun. 2011.

${ }^{44}$ RULLI NETO, Antonio. Op. cit., p. 34.
} 
Assim sendo, no presente trabalho serão utilizadas como sinônimas, no sentido da língua portuguesa, as terminologias "pessoa deficiente" (expressão mais sintética) ou "pessoa com deficiência" (expressão mais alargada) para englobar todas as formas de deficiências, entendendo ser esta a expressão mais alinhada com a visão contemporânea.

\subsection{Abrangência do conceito de "pessoa com deficiência"}

De introito, cumpre destacar que o conceito de pessoa com deficiência foi abordado no ordenamento jurídico brasileiro e em inúmeros instrumentos internacionais.

Da mesma forma como traçado nas linhas pretéritas sobre a questão terminológica, delimitar um conceito sobre a pessoa com deficiência requer uma análise detalhada dos posicionamentos doutrinários, bem como das normas e instrumentos legais nacionais e internacionais, tendo em vista sua amplitude e complexidade.

Convém destacar, segundo a Convenção Internacional sobre os Direitos das Pessoas com Deficiência, ratificada pelo Brasil através do Decreto n. 6.949 de 25 de agosto de 2009, que:

pessoas com deficiência são aquelas que têm impedimentos de longo prazo de natureza física, mental, intelectual ou sensorial, os quais, em interação com diversas barreiras, podem obstruir sua participação plena e efetiva na sociedade em igualdades de condições com as demais pessoas. ${ }^{45}$

Seguindo essa mesma linha, Sandro Nahmias Melo considera que as pessoas com deficiências:

são pessoas com certos níveis de limitação, física, mental ou sensorial, associados ou não, que demandam ações compensatórias por parte dos próprios portadores, do Estado e da sociedade, capazes de reduzir ou eliminar tais limitações, viabilizando a integração social dos mesmos. ${ }^{46}$

\footnotetext{
${ }^{45}$ BRASIL. Decreto n. 6.949/2009. Op. cit.

${ }^{46}$ MELO, Sandro Nahmias. Op. cit., p. 52.
} 
O conceito ora mencionado destaca a necessidade de medidas compensatórias por parte do Estado e da sociedade, mas também atitudes afirmativas e positivas por parte da própria pessoa com deficiência, tendo em vista sua capacidade de superar as limitações e integrar-se à sociedade.

Nesta senda, a Convenção n. 159 da Organização Internacional do Trabalho (OIT), ratificada pelo Brasil através do Decreto n. 129, de 18 de maio de 1991, considera: "pessoa deficiente todas as pessoas cujas possibilidades de obter e conservar um emprego adequado e de progredir no mesmo fiquem substancialmente reduzidas por deficiência de caráter físico ou mental devidamente comprovada." ${ }^{, 47}$

Assim sendo, resta claro que referido conceito destaca o caráter funcional das deficiências físicas ou sensoriais e determina a observância, pelos países signatários, do engajamento nas atividades de integração e viabilização das atividades profissionais desta categoria diferenciada. ${ }^{48}$

Outra norma internacional devidamente ratificada pelo Brasil, sendo-lhe, portanto, conferida a condição de lei nacional, é a Convenção Interamericana para a Eliminação de Todas as Formas de Discriminação contra as Pessoas Portadoras de Deficiência, também denominada como Convenção da Guatemala. Referida norma conceitua o termo "deficiência" como sendo: "uma restrição física, mental ou sensorial, de natureza permanente ou transitória, que limita a capacidade de exercer uma ou mais atividades essenciais da vida diária, causada ou agravada pelo ambiente econômico e social". 49

Atualmente, o ordenamento jurídico brasileiro define deficiência, deficiência permanente e incapacidade com base no art. $3^{\circ}$ do Decreto n. 3.298, de 20 de dezembro de 1999, a saber:

${ }^{47}$ ORGANIZAÇÃO INTERNACIONAL DO TRABALHO - OIT. Conferência Internacional do Trabalho

- Convenção n. 159. Disponível em: 〈http://www.mte.gov.br/fisca_trab/inclusao/legislacao_2_1.asp>. Acesso em: 10 jul. 2011.

${ }^{48}$ GUGEL, Maria Aparecida. O trabalho do portador de deficiência: comentários ao decreto n. 3.298/99. Gênesis - Revista de Direito do Trabalho. Curitiba: Gênesis, v. 15, n. 88, p. 564-572, abr. 2000.

49 BRASIL. Decreto n. 3.956, de 8 de outubro de 2001. Disponível em: 
I - deficiência - toda perda ou anormalidade de uma estrutura ou função psicológica, fisiológica ou anatômica que gere incapacidade para o desempenho de atividade, dentro do padrão considerado normal para o ser humano;

II - deficiência permanente - aquela que ocorreu ou se estabilizou durante um período de tempo suficiente para não permitir recuperação ou ter probabilidade de que se altere, apesar de novos tratamentos; e

III - incapacidade - uma redução efetiva e acentuada da capacidade de integração social, com necessidade de equipamentos, adaptações, meios ou recursos especiais para que a pessoa portadora de deficiência possa receber ou transmitir informações necessárias ao seu bem-estar pessoal e ao desempenho de função ou atividade a ser exercida. ${ }^{50}$

Ato contínuo, uma leitura atenta do art. $4^{\circ}$ do Decreto n. 3.298/99, cuja redação foi atualizada após inúmeras discussões pelo Decreto n. 5.296, de 2004, aflora uma conceituação técnica almejada pelo legislador, no sentido de definir qual a deficiência capaz de receber a proteção jurídica.

Neste diapasão, são consideradas pessoas com deficiências as que se enquadram nas seguintes categorias:

I - deficiência física - alteração completa ou parcial de um ou mais segmentos do corpo humano, acarretando o comprometimento da função física, apresentando-se sob a forma de paraplegia, paraparesia, monoplegia, monoparesia, tetraplegia, tetraparesia, triplegia, triparesia, hemiplegia, hemiparesia, ostomia, amputação ou ausência de membro, paralisia cerebral, nanismo, membros com deformidade congênita ou adquirida, exceto as deformidades estéticas e as que não produzam dificuldades para o desempenho de funções;

II - deficiência auditiva - perda bilateral, parcial ou total, de quarenta e um decibéis $(\mathrm{dB})$ ou mais, aferida por audiograma nas frequiências de $500 \mathrm{HZ}, 1.000 \mathrm{HZ}, 2.000 \mathrm{~Hz}$ e $3.000 \mathrm{~Hz}$;

III - deficiência visual - cegueira, na qual a acuidade visual é igual ou menor que 0,05 no melhor olho, com a melhor correção óptica; a baixa visão, que significa acuidade visual entre 0,3 e 0,05 no melhor olho, com a melhor correção óptica; os casos nos quais a somatória da medida do campo visual em ambos os olhos for igual ou menor que $60^{\circ}$; ou a ocorrência simultânea de quaisquer das condições anteriores;

IV - deficiência mental - funcionamento intelectual significativamente inferior à média, com manifestação antes dos dezoito anos e limitações associadas a duas ou mais áreas de habilidades adaptativas; e V - deficiência múltipla - associação de duas ou mais deficiências. ${ }^{51}$

<http://www.planalto.gov.br/ccivil_03/decreto/2001/d3956.htm>. Acesso em: 10 jul. 2011.

50 BRASIL. Decreto n. 3.298, de 20 de dezembro de 1999. Disponível em: <http://www.planalto.gov.br/ccivil_03/decreto/d3298.htm>. Acesso em: 18 dez. 2012.

${ }^{51}$ BRASIL. Decreto n. 3.298/1999. Op. cit. 
Tendo em vista os termos técnicos utilizados no artigo $4^{\circ}$, inciso I, da norma ora ventilada, se faz necessário para melhor entendimento do tema um estudo das definições utilizadas no tocante à deficiência física, a saber:

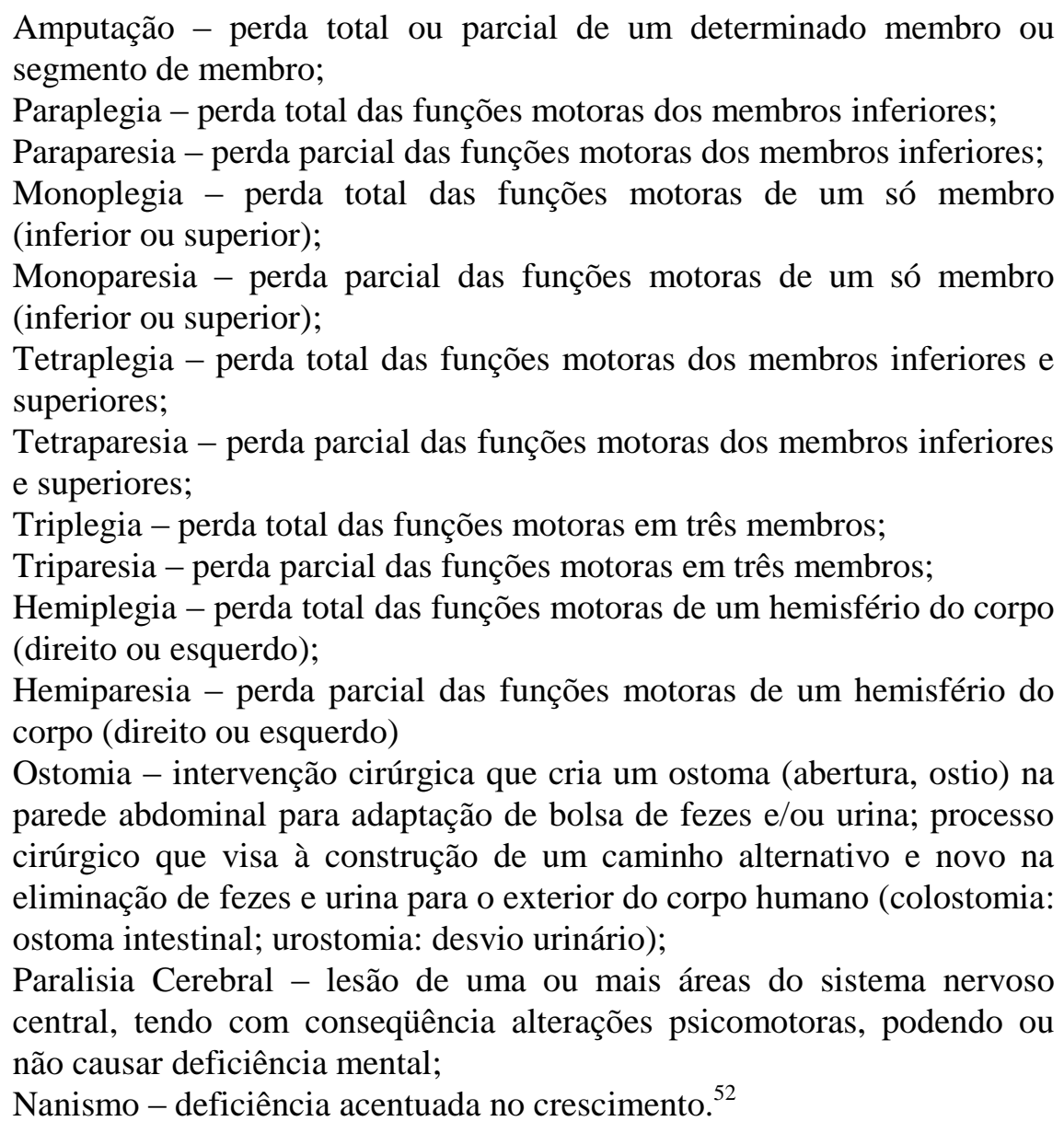

No tocante à visão monocular — apesar da ausência de previsão no Decreto $\mathrm{n}$. 3.298/99, mas em razão da publicação da Lei n. 14.481, do Estado de São Paulo, de 13 de julho de 2011 —, que será abordada pelo presente trabalho em capítulo específico, resta classificada como deficiência visual.

Portanto, destaca-se que as pessoas com surdez unilateral, com deficiência mental leve, ou ainda com deficiência física que não implique na impossibilidade de execução

${ }^{52}$ BRASIL. Ministério do Trabalho e Emprego. A inclusão das pessoas com deficiência... Op. cit., p. 21. 
normal das atividades do $\operatorname{corpo}^{53}$ não são computadas pela norma regulamentar como pessoas com deficiências.

Nesta linha, sob o prisma do ordenamento jurídico brasileiro, a conceituação da pessoa com deficiência decorre da interpretação conjunta do conceito inserido na Convenção n. 159 da OIT, bem como da análise dos arts. $3^{\circ}$ e $4^{\circ}$ do Decreto n. 3.298/99, com as alterações introduzidas pelo Decreto n. $5.296 / 04^{54}$ e a observância da Lei n. 14.481/11, do Estado de São Paulo.

Por fim, e com absoluto realce, utilizando como base estrutural a função social do Direito do Trabalho, observa-se que a pessoa com deficiência não pode ser considerada incapaz para o trabalho, existindo a plena possibilidade de inserção social, um direito inviolável e constitucionalmente garantido.

\footnotetext{
${ }^{53}$ BRASIL. Ministério do Trabalho e Emprego. A inclusão das pessoas com deficiência... Op. cit., p. 19.

${ }^{54}$ COSTA, Sandra Morais de Brito. Dignidade humana e pessoa com deficiência: aspectos legais e trabalhistas. São Paul: LTr, 2008.
} 


\section{AS NORMAS DE PROTEÇÃO DA PESSOA COM DEFICIÊNCIA NO ÂMBITO INTERNACIONAL}

No tocante aos direitos e garantias da pessoa com deficiência no panorama internacional, serão abordadas algumas considerações referentes às declarações, normas e convenções elaboradas pela Organização das Nações Unidas (ONU), pela Organização Internacional do Trabalho (OIT), pela Organização dos Estados Americanos (OEA) e pela União Europeia, e, ainda, será realizada uma análise comparativa de algumas normas abrangidas pelo Direito estrangeiro.

Nota-se que as normas internacionais sempre exerceram forte influência sobre o constituinte brasileiro, sendo necessário um estudo profundo desta legislação internacional específica.

Assim sendo, para aprimorar o estudo do tema ora apresentado, procurar-se-á traçar uma linha do tempo, apontando uma evolução das diretrizes tomadas pelas organizações internacionais quanto à elaboração de normas destinadas a resguardar os direitos e garantias da pessoa com deficiência.

\subsection{Organização das Nações Unidas - ONU}

A Organização das Nações Unidas (ONU), fundada em 24 de outubro de 1945 e formada por países reunidos voluntariamente para trabalhar pela paz e pelo desenvolvimento mundiais, ${ }^{55}$ foi responsável pela elaboração de um dos mais importantes instrumentos internacionais, a Declaração Universal dos Direitos Humanos, aprovada pela Assembleia Geral das Nações Unidas em 1948 como resposta às atrocidades cometidas durante a Segunda Guerra Mundial. Assim sendo, é possível afirmar que este instrumento influenciou inúmeros programas e outros documentos posteriormente elaborados e relacionados ao direito da pessoa com deficiência. ${ }^{56}$

55 ORGANIZAÇÃO DAS NAÇÕES UNIDAS - ONU. Conheça a ONU. Disponível em: <http://onu.org.br/conheca-a-onu>. Acesso em: 16 nov. 2012. 
Neste caminho, Fábio Konder Comparato destaca que: “Os direitos definidos na Declaração de 1948 correspondem, integralmente, ao que o costume e os princípios jurídicos internacionais reconhecem, hoje, como exigências básicas de respeito à dignidade humana". 57

Portanto, relevantes valores foram traçados e sopesados pela referida Declaração, como, por exemplo, a capacidade de gozar de direitos e liberdades sem distinção de qualquer espécie (raça, cor, sexo, língua, religião ou qualquer outra natureza ou condição), o direito à vida, a proibição de toda e qualquer forma de escravidão, o direito de locomoção, a liberdade de expressão e pensamento, e, ainda, o reconhecimento de direitos relacionados às condições de trabalho.

Assim sendo, a Declaração aborda com clareza o reconhecimento do direito à seguridade social e ao trabalho como direitos universais do homem:

Artigo XXII - Todo ser humano, como membro da sociedade, tem direito à segurança social, à realização pelo esforço nacional, pela cooperação internacional e de acordo com a organização e recursos de cada Estado, dos direitos econômicos, sociais e culturais indispensáveis à sua dignidade e ao livre desenvolvimento da sua personalidade.

Artigo XXIII - 1. Todo ser humano tem direito ao trabalho, à livre escolha de emprego, a condições justas e favoráveis de trabalho e à proteção contra o desemprego.

2. Todo ser humano, sem qualquer distinção, tem direito a igual remuneração por igual trabalho.

3. Todo ser humano que trabalha tem direito a uma remuneração justa e satisfatória, que lhe assegure, assim como à sua família, uma existência compatível com a dignidade humana e a que se acrescentarão, se necessário, outros meios de proteção social.

4. Todo ser humano tem direito a organizar sindicatos e a neles ingressar para proteção de seus interesses ${ }^{.58}$

Em resumo, referido instrumento pode ser entendido como o alicerce da luta universal contra a opressão e a discriminação, ao passo que constitui uma importante

\footnotetext{
${ }^{56}$ GOLDFARB, Cibelle Linero. Op. cit., p. 48.

${ }^{57}$ COMPARATO, Fábio Konder. A afirmação histórica dos direitos humanos. 3. ed. São Paulo: Saraiva, 2004, p. 224.

${ }^{58}$ ORGANIZAÇÃO DAS NAÇÕES UNIDAS - ONU. Declaração Universal dos Direitos Humanos. Disponível em: <http://unicrio.org.br/img/DeclU_D_HumanosVersoInternet.pdf>. Acesso em: 16 nov. 2012.
} 
conquista dos direitos humanos e marco primordial do reconhecimento dos direitos fundamentais.

Seguindo neste mesmo caminho, e demonstrando como é recente a preocupação com a pessoa com deficiência, no dia 20 de dezembro de 1971 a Assembleia Geral das Nações Unidas promulgou a Declaração de Direitos do Deficiente Mental, que traçou pontualmente os direitos e as formas de proteção do deficiente mental, tendo sido abordados inúmeros aspectos, dentre eles a segurança econômica, a ocupação útil e, ainda, a proteção tutelar especializada.

Assim sendo, ampliando este reconhecimento de direitos e garantias, em 9 de dezembro de 1975 foi aprovada pela ONU a Declaração dos Direitos das Pessoas Portadoras de Deficiência, garantindo a igualdade de direitos, sem exceção, distinção ou discriminação decorrente de qualquer motivo, com intuito de assegurar a dignidade humana.

Resta claro que referida Declaração tratou da necessidade de se legislar sobre medidas que alcançassem à capacitação das pessoas com deficiências, para que as necessidades desta categoria de pessoas fossem observadas e consideradas quando do planejamento econômico e social de todos os países:

5. As pessoas deficientes têm direito a medidas que visem capacitá-las a torná-las tão autoconfiantes quanto possível.

6. As pessoas deficientes têm direito a tratamento médico, psicológico e funcional, incluindo-se aí aparelhos protéticos e ortóticos, à reabilitação médica e social, educação, treinamento vocacional e reabilitação, assistência, aconselhamento, serviços de colocação e outros serviços que lhes possibilitem o máximo desenvolvimento de sua capacidade e habilidades e que acelerem o processo de sua integração social.

7. As pessoas deficientes têm direito à segurança econômica e social e a um nível de vida decente e, de acordo com suas capacidades, a obter e manter um emprego ou desenvolver atividades úteis, produtivas e remuneradas e a participar de sindicatos.

8. As pessoas deficientes têm direito de ter suas necessidades especiais levadas em consideração em todos os estágios de planejamento econômico e social. ${ }^{59}$

${ }^{59}$ ORGANIZAÇÃO DAS NAÇÕES UNIDAS - ONU. Declaração dos Direitos das Pessoas Portadoras de Deficiência. Disponível em: <http://www.mte.gov.br/fisca_trab/inclusao/legislacao_2_4.asp>. Acesso em: 16 nov. 2012. 
Visando viabilizar o processo de integração social das pessoas com deficiências, restou incluído no texto da Declaração o direito ao tratamento médico, psicológico e funcional, bem como aspectos destinados à reabilitação médica e social.

Ato contínuo, em 1982 foi aprovado pela ONU o Programa de Ação Mundial para as Pessoas com Deficiência, Resolução n. 37/52, contendo como princípios básicos a igualdade de oportunidades, de educação e de trabalho, buscando uma participação plena desses indivíduos. A Assembleia Geral das Nações Unidas, através da Resolução n. 37/52, proclamou a United Nations Decade of Disabled Persons, compreendendo os anos de 1983 até 1992. E, ao final do mencionado lapso temporal, em 14 de outubro de 1992, foi instituído pela ONU o Dia do Deficiente (3 de dezembro). ${ }^{60}$

Referido programa elencou diversas medidas a serem adotadas pelos países como forma de viabilizarem a execução dos objetivos traçados, como, por exemplo, a criação de bases jurídicas e legislação específica acerca dos direitos à educação, ao trabalho, à seguridade social, a proteção contra tratamento desumano ou degradante, o acesso ao meio físico (transporte público e acesso aos edifícios e instalações públicas), entre outros. ${ }^{61}$

Utilizando como base a experiência adquirida durante a Década das Nações Unidas para as Pessoas com Deficiências (1983-1992), no ano de 1993 a ONU aprovou as Normas sobre Equiparação de Oportunidades, sublinhando que as pessoas com deficiências, bem como seus pais, tutores e organizações, devem participar ativamente no planejamento e execução de todas as medidas que possam afetar os direitos civis, políticos, econômicos, sociais e culturais. ${ }^{62}$

Nesse passo, em 1994 quando da aprovação da Declaração de Salamanca, restou

\footnotetext{
${ }^{60}$ COSTA, Sandra Morais de Brito. Op. cit., p. 25.

${ }^{61}$ GOLDFARB, Cibelle Linero. Op. cit., p. 54.

${ }^{62}$ FUNDAÇÃO DE ARTICULAÇÃO E DESENVOLVIMENTO DE POLÍTICAS PÚBLICAS PARA PCD E PCAH NO RIO GRANDE DO SUL - FADERS. Cartilha Atitudes que fazem a diferença com PCD. Disponível em: <http://www.faders.rs.gov.br/portal/index.php?id=ligislacao\&cat=6>. Acesso em: 17 nov. 2012.
} 
destacada a preocupação com a educação especial para a pessoa com deficiência. ${ }^{63}$

Assim, sem estender a análise acerca de todos os instrumentos aprovados pela ONU e relacionados à pessoa com deficiência, necessário mencionar, por fỉm, a Convenção Internacional sobre os Direitos das Pessoas com Deficiência e seu Protocolo Facultativo, assinados em Nova York no dia 30 de março de 2007. Considerando que o Brasil depositou o instrumento de ratificação em $1^{\circ}$ de agosto de 2008 , restou promulgada a referida Convenção através do Decreto n. 6.949, de 25 de agosto de $2009 .{ }^{64}$

Trata-se de relevante instrumento de aprimoramento dos direitos humanos, reconhecendo que a discriminação contra qualquer pessoa, por motivo de deficiência, configura violação da dignidade e do valor inerente ao ser humano, e, ainda, aprofundando a preocupação com o fato de que, não obstante diversos instrumentos e compromissos elaborados, as pessoas com deficiências continuam a enfrentar barreiras contra sua participação como membros iguais da sociedade e violações de seus direitos humanos em todas as partes do mundo.

Necessário salientar que a Convenção é o tratado de direitos humanos que mais rapidamente restou aprovado na história do Direito Internacional, sendo assim o resultado de inúmeras negociações que se iniciaram quando da criação de um comitê especial para sua elaboração em $2002 .^{65}$

\subsection{Organização Internacional do Trabalho - OIT}

A Organização Internacional do Trabalho (OIT) foi criada em 1919 como parte do Tratado de Versalhes, que colocou fim à Primeira Guerra Mundial, sendo certo que passou a editar normas denominadas “convenções" e "recomendações". Destaca-se que a OIT é a única das agências do Sistema das Nações Unidas com uma estrutura tripartite, composta

\footnotetext{
${ }^{63}$ ORGANIZAÇÃO DAS NAÇÕES UNIDAS - ONU. Declaração de Salamanca sobre princípios, políticas e práticas na área das necessidades educativas especiais. Disponível em: <http://portal.mec.gov.br/seesp/arquivos/pdf/salamanca.pdf>. Acesso em: 17 nov. 2012.

${ }^{64}$ BRASIL. Decreto n. 6.949/2009. Op. cit.

${ }^{65}$ COSTA, Sandra Morais de Brito. Op. cit, p. 69.
} 
por representantes de governos e de organizações de empregadores e de trabalhadores. ${ }^{66}$

Neste caminho, cumpre destacar os quatro objetivos estratégicos da OIT:

(i) liberdade sindical e reconhecimento efetivo do direito de negociação coletiva;

(ii) eliminação de todas as formas de trabalho forçado;

(iii) abolição efetiva do trabalho infantil;

(iv) eliminação de todas as formas de discriminação em matéria de emprego e ocupação, a promoção do emprego produtivo e de qualidade, a extensão da proteção social e o fortalecimento do diálogo social. ${ }^{67}$

Segundo o posicionamento do doutrinador Arnaldo Lopes Süssekind:

A atividade normativa da OIT, desde sua criação, importou numa significativa inovação do Direito Internacional, porquanto as convenções adotadas nas sucessivas reuniões da sua Conferência contêm normas cujo destino é a incorporação ao direito interno dos Estados que manifestarem sua adesão. Como escrevemos alhures, com esses tratados multilaterais, abertos à ratificação dos Estados-membros da Organização, o Direito Internacional Público não mais se limitou a dispor sobre as relações exteriores dos Estados. E, sobretudo após a segunda guerra mundial, a ONU e os organismos internacionais especializados que integram o seu sistema, assim como instituições regionais, passaram a adotar o modelo utilizado com sucesso pela OIT. ${ }^{68}$

Seguindo este entendimento, necessário ponderar que, quando ratificada a convenção, esta passa a ter força normativa e a integrar o Direito positivo dos Estados signatários, sendo certo que cria obrigações internacionais. Por outra esteira, as recomendações constituem meras sugestões aprovadas pelas conferências no tocante aos pontos que serão incorporados às convenções, ou seja, apenas orientam a ação dos Estadosmembros.

Assim sendo, comprovando o aumento do interesse da comunidade internacional sobre o tema, em 1955 ocorreu a publicação da Recomendação n. 99, sendo este o primeiro

${ }^{66}$ ORGANIZAÇÃO INTERNACIONAL DO TRABALHO - OIT. História. Disponível em: <http:// www.oit.org.br/content/hist\%C3\%B3ria>. Acesso em: 17 nov. 2012.

${ }^{67}$ ORGANIZAÇÃO INTERNACIONAL DO TRABALHO - OIT. Apresentação. Disponível em: <http://www.oit.org.br/content/apresenta\%C3\%A7\%C3\%A3o>. Acesso em: 20 nov. 2012.

${ }^{68}$ SÜSSEKIND, Arnaldo Lopes. Direito Constitucional do Trabalho. Rio de Janeiro: Renovar, 1999, p. 6566. 
texto elaborado pela OIT sobre a relação de emprego da pessoa com deficiência, a qual declarou que todos os indivíduos com limitações, de qualquer origem ou natureza, têm direitos aos meios de reabilitação profissional para que possam exercer um labor adequado às suas limitações. ${ }^{69}$

De acordo com o texto da Recomendação, é necessário direcionar a atenção dos Estados para organizar e desenvolver programas contínuos e coordenados de serviços de adaptação e readaptação profissional, utilizando-se da colaboração de outros organismos públicos e da coordenação de atividades entre todas as entidades encarregadas de tratamento e reintegração das pessoas com deficiências. ${ }^{70}$

Referida Recomendação sugere que todos os meios de readaptação profissional sejam colocados à disposição das pessoas com deficiências, independentemente da origem ou natureza da deficiência, estimulando-se, inclusive, que os empregadores proporcionem formação profissional para os deficientes. Acrescenta, por fim, que a adaptação e readaptação profissional devem ser ajustadas às necessidades e às circunstâncias de cada país.

Nesta mesma linha, Cibelle Linero Goldfarb aborda o texto da Recomendação, nos seguintes termos:

Segundo a Recomendação 99, as medidas para aumentar as oportunidades de obtenção e manutenção de emprego pelas pessoas portadoras de deficiências devem ser adotadas, tanto quanto possível, em estreita cooperação com organizações de empregadores e de trabalhadores e devem pautar-se nos seguintes princípios: (a) as pessoas portadoras de deficiências devem gozar, do mesmo modo que as pessoas não-portadoras de deficiência, da oportunidade de serem admitidas em trabalho para o qual estejam qualificadas; (b) as pessoas portadoras de deficiências devem ter a ampla oportunidade de aceitar o trabalho que lhes convenha com empregadores de sua própria escolha e (c) devem ser enfatizadas as habilidades e as capacidades de trabalho das pessoas portadoras de deficiência.

Já sinalizando a possibilidade de introdução de uma política de cotas, prevê a Recomendação que, sempre que compatível com a política nacional, o emprego de pessoas portadoras de deficiência deve ser

${ }^{69}$ MELO, Sandro Nahmias. Op. cit., p. 90.

${ }^{70}$ LOPES, Glaucia Gomes Vergara. A inserção do portador de deficiência no mercado de trabalho: a efetividade das leis brasileiras. São Paulo: LTr, 2005, p. 26. 
promovido mediante: (a) contratação, por empregadores, de um percentual de pessoas portadoras de deficiência que não acarrete a dispensa de outros trabalhadores; (b) reserva de determinadas ocupações para pessoas portadoras de deficiência; (c) dispositivos que permitam dar às pessoas portadoras de graves deficiências oportunidades de emprego ou preferência em certas ocupações consideradas adequadas; e (d) incentivo para a criação e a instalação de cooperativas ou outros estabelecimentos similares geridos por pessoas portadoras de deficiência ou em seu nome. ${ }^{71}$

É preciso sopesar, ainda, que a Recomendação surgiu em um período posterior à Segunda Guerra Mundial, sendo certo que a quantidade numerosa dos mutilados de guerra foi responsável por uma imensa parcela das contas da previdência social dos países envolvidos nos conflitos. Assim sendo, apesar do cunho assistencialista, este foi o início da reintegração das pessoas com deficiências ao mercado de trabalho. ${ }^{72}$

Ato contínuo, visando afastar uma das práticas mais corriqueiras no mundo do trabalho, a discriminação, a Convenção n. 111 foi adotada pela Conferência Geral da OIT em 1958, e aprovada no Brasil pelo Decreto Legislativo n. 104, de 24 de novembro de 1964, sendo ratificada em 26 de novembro de 1965, entrando em vigor após um ano, em 26 de novembro de $1966^{73}$

Portanto, para os fins da referida Convenção o termo "discriminação" compreende:

a) toda distinção, exclusão ou preferência fundada na raça, cor, sexo, religião, opinião política, ascendência nacional ou origem social, que tenha por efeito destruir ou alterar a igualdade de oportunidade ou de tratamento em matéria de emprego ou profissão.

b) qualquer outra distinção, exclusão ou preferência que tenha por efeito destruir ou alterar a igualdade de oportunidades ou tratamento em matéria de emprego ou profissão que poderá ser especificada pelo Membro interessado depois de consultadas as organizações representativas de empregadores e trabalhadores, quando estas existam, e outros organismos adequados.

2. As distinções, exclusões ou preferências fundadas em qualificações exigidas para um determinado emprego não são consideradas como discriminação. $^{74}$

\footnotetext{
${ }^{71}$ GOLDFARB, Cibelle Linero. Op. cit., p. 44-45.

${ }^{72}$ LOPES, Gláucia Gomes Vergara. Op. cit., p. 26-27.

${ }^{73}$ ORGANIZAÇÃO INTERNACIONAL DO TRABALHO - OIT. Discriminação em matéria de emprego e ocupação. Disponível em: <http://www.oit.org.br/node/472>. Acesso em: 17 nov. 2012.

${ }^{74}$ Ibidem.
} 
Da análise do texto em comento, denota-se que não serão consideradas discriminações as distinções, exclusões ou preferências fundadas em qualificações exigidas para um determinado emprego.

Assim sendo, a Convenção n. 111 não só define o que seria discriminação, mas estabelece o compromisso dos países signatários quanto à formulação e aplicação de uma política nacional voltada a promover a igualdade de oportunidades e tratamento em matéria de emprego, sendo certo que, de acordo com o texto da Convenção, as medidas cabíveis sugeridas são:

a) esforçar-se por obter a colaboração das organizações de empregadores e trabalhadores e de outros organismos apropriados, com o fim de favorecer a aceitação e aplicação desta política;

b) promulgar leis e encorajar os programas de educação próprios a assegurar esta aceitação e esta aplicação;

c) revogar todas as disposições legislativas e modificar todas as disposições ou práticas administrativas que sejam incompatíveis com a referida política;

d) seguir a referida política no que diz respeito a empregos dependentes do controle direto de uma autoridade nacional;

e) assegurar a aplicação da referida política nas atividades dos serviços de orientação profissional, formação profissional e colocação dependentes do controle de uma autoridade nacional;

f) indicar, nos seus relatórios anuais sobre a aplicação da convenção, as medidas tomadas em conformidade com esta política e os resultados obtidos. ${ }^{75}$

Importante mencionar que a Convenção busca valorizar o princípio da igualdade e evidenciar a necessidade de medidas práticas de integração das pessoas com deficiências ao mercado de trabalho, destacando-se inclusive que, no tocante ao conceito de emprego e profissão, inclui-se o acesso à formação profissional, ao emprego e às diferentes profissões e às condições de emprego.

Outra Convenção que merece especial atenção é a Convenção n. 159, sendo certo que restou aprovada pela Conferência Internacional do Trabalho em 1983. Ato contínuo, referida Convenção foi aprovada pelo Brasil através do Decreto Legislativo n. 51 de 25 de

${ }^{75}$ OIT. Discriminação em matéria de emprego e ocupação. Op. cit. 
agosto de 1989 e ratificada em 18 de maio de 1990, entrando em vigor um ano após, em 18 de maio de 1991.

A Convenção n. 159 define o conceito de pessoa com deficiência alinhando os seguintes parâmetros: “[...] todas as pessoas cujas possibilidades de obter e conservar um emprego adequado e de progredir no mesmo fiquem substancialmente reduzidas devido a uma deficiência de caráter físico ou mental devidamente comprovada." ${ }^{76}$

Reforçando a ideia destacada na Convenção n. 111, a Convenção n. 159 adota o princípio da igualdade de oportunidades entre os trabalhadores deficientes e os trabalhadores em geral, através de medidas estatais positivas.

Art. 4 - Essa política deverá ter como base o princípio da igualdade de oportunidades entre os trabalhadores deficientes e dos trabalhadores em geral. Dever-se-á respeitar a igualdade de oportunidades e de tratamento para as trabalhadoras deficientes. As medidas positivas especiais com a finalidade de atingir a igualdade efetiva de oportunidades e de tratamento entre os trabalhadores deficientes e os demais trabalhadores, não devem ser vistas como discriminatória em relação a estes últimos. ${ }^{77}$

Portanto, resta cristalino que as medidas positivas oriundas do Poder Estatal não configuram discriminação, e sim corroboram para o alcance da igualdade efetiva de oportunidades e de tratamento entre os trabalhadores deficientes e os demais trabalhadores.

Assim sendo, ratificar a Convenção n. 159 significa obrigar-se a formular, aplicar e revisar continuamente a política nacional referente à readaptação profissional e ao emprego da pessoa com deficiência, devendo ser observadas as condições nacionais, experiências e possibilidades de cada país-membro.

Segundo o entendimento da doutrinadora Glaucia Gomes Vergana Lopes:

A finalidade primordial dessa política é a de assegurar que existam medidas adequadas de reabilitação profissional ao alcance de todas as categorias de pessoas portadoras de deficiência e promover

\footnotetext{
${ }^{76}$ ORGANIZAÇÃO INTERNACIONAL DO TRABALHO - OIT. Reabilitação profissional e emprego de pessoas deficientes. Disponível em: <http://www.oit.org.br/node/505>. Acesso em: 18 nov. 2012.

${ }^{77}$ Ibidem.
} 
oportunidades de emprego para as mesmas no mercado regular de trabalho. ${ }^{78}$

É possível entender que umas das justificativas para a elaboração da Convenção n. 159 tenha sido o relevante progresso observado após a elaboração da Recomendação n. 99, no tocante à real compreensão das necessidades de reabilitação e organização dos serviços de reabilitação, bem como ao avanço da legislação sobre o tema.

Neste caminho, Guilherme José Purvin de Figueiredo traçou um comparativo entre os seguintes textos:

Confrontando-se os textos da OIT — de um lado a Recomendação n. 99 e, de outro, a Convenção n. 159 e a Recomendação n. 168 - nota-se uma significativa evolução. Com efeito, à época da Recomendação n. 99, a OIT analisava a forma de assistência ao portador de deficiência, para que este se ajustasse às necessidades do mercado de trabalho. Em outras palavras, a OIT ainda não levava em consideração a necessidade de adoção, pela sociedade, de uma atitude de reconhecimento do portador de deficiência como parte da comunidade, com necessidades que devem ser atendidas para que sua participação social se dê de forma isonômica. Os textos subseqüentes, adotados pela Conferência Internacional do Trabalho, em 1983, dentro de uma nova perspectiva, passam a enfatizar a necessidade de um desenvolvimento dinâmico da comunidade na busca da promoção de serviços de habilitação e reabilitação profissional, assim como de oportunidades de trabalho para as pessoas portadoras de deficiência. ${ }^{79}$

Assim, como será traçado nas linhas futuras do presente trabalho, a mencionada diferença foi observada inclusive na legislação brasileira, sendo certo que inicialmente a pessoa com deficiência era tratada unicamente sob o enfoque assistencialista e, posteriormente, buscou-se observar a reintegração ao convívio social e ao mercado de trabalho.

Nota-se que o texto da Convenção n. 159 incentiva a consulta às organizações representativas de empregadores e de empregados, e às organizações representativas da pessoa com deficiência, no tocante à aplicação das medidas a serem adotadas para

\footnotetext{
${ }^{78}$ LOPES, Gláucia Gomes Vergara. Op. cit., p. 36.

${ }^{79}$ FIGUEIREDO, Guilherme José Purvin de. A pessoa portadora de deficiência física e o princípio da igualdade de oportunidades no direito do trabalho. In: Direitos da pessoa portadora de deficiência. Coleção Advocacia Pública \& Sociedade, n. 1, São Paulo: IBAP - Instituto Brasileiro de Advocacia Pública; Max
} 
promover a cooperação dos organismos públicos e particulares que participam nas atividades de reabilitação profissional.

Por derradeiro, resta mencionar que em 1983 a OIT adotou a Recomendação n. 168 sobre readaptação profissional e emprego de pessoas com deficiências e apontou inúmeras diretrizes relativas à necessidade de adoção de políticas de inclusão ao mercado de trabalho das pessoas com deficiências.

Cibelle Linero Goldfarb, de forma escorreita, sintetiza as diretrizes traçadas pela referida Recomendação, a saber:

(a) incentivos econômicos a empregadores que ofereçam treinamento e
emprego a pessoas portadoras de deficiência; (b) apoio à criação de
emprego protegido; (c) cooperação entre oficinas protegidas e de
produção; (d) apoio a serviços de treinamento profissional, orientação
vocacional, de emprego protegido e de colocação administrados por
organizações não-governamentais; (e) criação e desenvolvimento de
cooperativas de pessoas portadoras de deficiência; (f) apoio à criação e
desenvolvimento de indústrias de pequeno porte, de cooperativas e de
outros tipos de oficinas de produção; (g) eliminação de barreiras e
obstáculos físicos, arquitetônicos e de comunicação; (h) facilitação de
adequados meios de transporte aos locais de reabilitação e de trabalho;
(i) divulgação de informação sobre casos concretos e bem sucedidos de
integração no mercado de pessoas portadoras de deficiência; (j) isençães
fiscais relativamente aos materiais relacionados a treinamento e
reabilitação; (k) criação de emprego de tempo parcial; (l) pesquisa e
aplicação de seus resultados; e (m) eliminação das possibilidades de
exploração no campo do treinamento profissional e do emprego
protegido. ${ }^{80}$

Portanto, é nítida a preocupação quanto à necessidade de extensão das políticas voltadas à reabilitação profissional, sendo reforçada a relevância da figura das associações de empregadores e empregados. Desta feita, a Recomendação n. 168 ratifica e complementa as orientações trazidas pela Recomendação n. 99.

\subsection{Organização dos Estados Americanos - OEA}

A Organização dos Estados Americanos (OEA) foi fundada em 1948 com a

Limonad, 1997, p. 97-104. 
assinatura, em Bogotá, Colômbia, da Carta da OEA, que entrou em vigor em dezembro de 1951. Ato contínuo, a Carta foi emendada por diversos Protocolos, sendo o último deles o Protocolo de Washington, assinado em 1992 e que entrou em vigor em setembro de $1997 .{ }^{81}$

Assim sendo, para cumprir os princípios em que se baseia e concretizar suas obrigações regionais, a OEA estabelece como propósitos essenciais os seguintes:

a) Garantir a paz e a segurança continentais;

b) Promover e consolidar a democracia representativa, respeitando o princípio da não-intervenção;

c) Prevenir as possíveis causas de dificuldades e assegurar a solução pacífica das controvérsias que surjam entre seus membros;

d) Organizar a ação solidária destes em caso de agressão;

e) Procurar a solução dos problemas políticos, jurídicos e econômicos que surgirem entre os Estados membros;

f) Promover, por meio da ação cooperativa, seu desenvolvimento econômico, social e cultural;

g) Erradicar a pobreza crítica, que constitui um obstáculo ao pleno desenvolvimento democrático dos povos do Hemisfério; e

h) Alcançar uma efetiva limitação de armamentos convencionais que permita dedicar a maior soma de recursos ao desenvolvimento econômico-social dos Estados membros. ${ }^{82}$

Atualmente a OEA congrega 35 Estados independentes das Américas e constitui o principal fórum governamental político, jurídico e social. Para atingir seus objetivos mais importantes, baseia-se nos seguintes pilares: a democracia, os direitos humanos, a segurança e o desenvolvimento. ${ }^{83}$

Seguindo os pilares ora indicados, o Conselho Permanente da Organização dos Estados Americanos aprovou, em 26 de maio de 1999, a Convenção Interamericana para eliminação de todas as formas de discriminação contra as pessoas portadoras de deficiência, sendo certo que no Brasil o Decreto n. 3.956, de 8 de outubro de 2001, promulgou a referida Convenção. ${ }^{84}$

${ }^{80}$ GOLDFARB, Cibelle Linero. Op. cit., p. 46.

81 ORGANIZAÇÃO DOS ESTADOS AMERICANOS - OEA. Quem somos. Disponível em: <http://www.oas.org/pt/sobre/quem_somos.asp>. Acesso em: 4 dez. 2012.

82 ORGANIZAÇÃO DOS ESTADOS AMERICANOS - OEA. Nosso propósito. Disponível em: <http://www.oas.org/pt/sobre/proposito.asp>. Acesso em: 4 dez. 2012.

${ }^{83}$ OEA. Quem somos. Op. cit. 
Da análise do texto da Convenção, destaca-se que restou reafirmado o conceito de que as pessoas deficientes têm os mesmos direitos humanos e liberdades fundamentais que as outras pessoas. E, ainda, em sua parte introdutória, foram observados todos os convênios e declarações internacionais anteriormente promulgados sobre o tema em deslinde.

A referida Convenção define os termos "deficiência" e "discriminação" destacando:

1. Deficiência: O termo "deficiência" significa uma restrição física, mental ou sensorial, de natureza permanente ou transitória, que limita a capacidade de exercer uma ou mais atividades essenciais da vida diária, causada ou agravada pelo ambiente econômico e social.

2. Discriminação contra as pessoas portadoras de deficiência:

a. o termo "discriminação contra as pessoas portadoras de deficiências" significa toda diferenciação, exclusão ou restrição baseada em deficiência, antecedente de deficiência, consequiência de deficiência anterior ou percepção de deficiência presente ou passada, que tenha o efeito ou propósito de impedir ou anular o reconhecimento, gozo ou exercício por parte das pessoas portadoras de deficiência de seus direitos humanos e suas liberdades fundamentais;

b. não constitui discriminação a diferenciação ou preferência adotada pelo Estado Parte para promover a integração social ou o desenvolvimento pessoal dos portadores de deficiência, desde que a diferenciação ou preferência não limite em si mesma o direito à igualdade dessas pessoas e que elas não sejam obrigadas a aceitar tal diferenciação ou preferência. Nos casos em que a legislação interna preveja a declaração de interdição, quando for necessária e apropriada para o seu bem estar esta não constituirá discriminação. ${ }^{85}$

De forma escorreita, o texto da Convenção prevê o comprometimento dos Estadospartes quanto à elaboração de medidas de caráter legislativo, social, educacional, trabalhista, ou de qualquer outra natureza, necessárias para eliminar a discriminação contra a pessoa deficiente, proporcionando, desta forma, a plena integração à sociedade.

Seguindo este caminho, resta destacado que os Estados-partes devem trabalhar prioritariamente na prevenção de todas as formas de deficiências, detecção e intervenção precoce, tratamento, reabilitação, educação, formação ocupacional e prestação de serviços completos para garantir o melhor nível de independência e qualidade de vida para as pessoas deficientes e sensibilização da população, através de campanhas de educação

\footnotetext{
${ }^{84}$ BRASIL. Decreto n. 3.956/2001. Op. cit.

${ }^{85}$ Ibidem.
} 
destinadas a eliminar preconceitos, estereótipos e outras atitudes que atentam contra o direito das pessoas a serem iguais, permitindo, dessa forma, o respeito e a convivência com as pessoas deficientes. ${ }^{86}$

Outro aspecto ventilado no texto da Convenção refere-se à necessidade de cooperação dos Estados-partes entre si, com intuito de contribuir para a prevenção e a eliminação da discriminação contra as pessoas deficientes, assim como para a colaboração de maneira efetiva no tocante à pesquisa científica e tecnológica relacionada com a prevenção das deficiências, o tratamento, a reabilitação e a integração de pessoas deficientes na sociedade e com o desenvolvimento de meios e recursos destinados a facilitar ou promover a vida independente a autossuficiência e a integração total, em condições de igualdade à sociedade.

Nesta senda, da análise dos inúmeros tratados internacionais é possível atentar ao debate traçado, bem como observar a preocupação da comunidade internacional quanto aos direitos e garantias das pessoas com deficiências, demonstrando um enorme avanço no tratamento da matéria.

\subsection{União Europeia - UE}

Inicialmente, importante ponderar que a União Europeia (UE) é uma parceria econômica e política com características únicas, constituída por 27 países europeus que, em conjunto, abarcam uma grande parte do continente europeu.

Nota-se que a UE foi criada com o objetivo de incentivar a cooperação econômica na Europa. Referida cooperação econômica resultou na criação da Comunidade Econômica Europeia (CEE) em 1958, inicialmente constituída por 6 países: Alemanha, Bélgica, França, Itália, Luxemburgo e Países Baixos. ${ }^{87}$

Perfilhando nesta senda, o Tratado da UE, assinado em 07 de fevereiro de 1992, na

\footnotetext{
${ }^{86}$ BRASIL. Decreto n. 3.956/2001. Op. cit.

87 UNIÃO EUROPEIA. Informações gerais sobre a União Europeia. Disponível em: <http:// europa.eu/about-eu/basic-information/index_pt.htm>. Acesso em: 4 dez. 2012.
} 
cidade holandesa de Maastrich, destacou liberdades fundamentais que passaram a reger a Comunidade Europeia, quais sejam: a livre circulação de mercadorias, a liberdade de estabelecimento de pessoas e livre circulação de pessoas, de serviços e de capitais. ${ }^{88,} 89$

Assim sendo, o que no início era apenas uma união econômica converteu-se em uma organização ativa em todos os domínios, desde a ajuda ao desenvolvimento até a política ambiental. Em 1993, esta evolução traduziu-se em uma alteração de nome, e a CEE passou a denominar-se União Europeia (UE).

A UE baseia-se no Estado de Direito, portanto toda a sua ação deriva de tratados democraticamente aprovados por todos os Estados-membros, sendo certo que nestes são definidos os objetivos da UE nos seus muitos domínios de intervenção.

Com intuito de concretizar as liberdades previstas, a UE passou a legislar sobre determinadas questões buscando alcançar uma uniformização das leis dos países-membros, mediante a observância dos regulamentos, decisões, recomendações e pareceres, todos estes fonte do Direito comunitário. ${ }^{90}$ Ademais, o Conselho Europeu costuma estabelecer, anualmente, um conjunto de orientações que fixam prioridades e objetivos para as políticas de emprego dos Estados-membros.

Nesse passo, cumpre sopesar que a UE conta com inúmeras normas sobre igualdade de tratamento no emprego e na atividade profissional, bem como dedica profunda análise à relação de emprego da pessoa com deficiência.

Desta feita, no tocante ao tema do presente trabalho, é possível destacar algumas Diretivas relacionadas à igualdade de tratamento na relação de emprego. Inicialmente, a Diretiva n. 76/207/CEE, datada de 9 de fevereiro de 1976, aborda a concretização do princípio da igualdade de tratamento entre homens e mulheres no que se refere ao acesso

\footnotetext{
${ }^{88}$ BELTRAN, Ari Possidonio. Os impactos da integração econômica no direito do trabalho: globalização e direitos sociais. São Paulo: LTr, 1998, p. 36.

${ }^{89}$ UNIÃO EUROPEIA. Jornal Oficial da União Europeia, ano 53, n. C83, 30 mar. 2010. Disponível em: <http://eur-lex.europa.eu/LexUriServ/LexUriServ.do?uri=OJ:C:2010:083:FULL:PT:PDF>. acesso em: 5 dez. 2012.

${ }^{90}$ GOLDFARB, Cibelle Linero. Op. cit., p. 58.
} 
ao emprego, à formação e à promoção profissionais e às condições de trabalho. ${ }^{91}$

Ato contínuo, a Diretiva n. 86/613/CEE, de 11 de dezembro de 1986, aborda a aplicação do princípio da igualdade de tratamento entre homens e mulheres que exerçam uma atividade independente, incluindo a atividade agrícola, bem como a proteção da maternidade. ${ }^{92}$ Outrossim, a Diretiva n. 2000/43/CE, de 29 de junho de 2000, trata sobre a igualdade de tratamento entre as pessoas, sem distinção de origem racial ou étnica, ${ }^{93}$ e, ainda, a Diretiva n. 2000/78/CE, de 27 de novembro de 2000, estabelece um quadro geral de igualdade de tratamento no emprego e na atividade profissional. ${ }^{94}$

Dentre todas as Diretivas mencionadas, necessário chamar a atenção para a Diretiva n. 2000/78/CE, que dispõem sobre a adoção de medidas de adaptação do local de trabalho às necessidades das pessoas deficientes, exercendo um papel importante na luta contra a discriminação em razão da deficiência. Assim sendo, para garantir a observância ao princípio da igualdade de tratamento no tocante às pessoas deficientes, são previstas adaptações razoáveis, ou seja, a entidade patronal deve adotar as medidas adequadas, em função das necessidades em uma situação concreta, para que uma pessoa deficiente tenha acesso a um emprego, podendo exercê-lo e nele progredir, ou para que lhe seja ministrada formação. Caso as medidas venham a implicar encargos desproporcionais para a entidade patronal, estes devem ser suficientemente compensados por medidas previstas pela política do Estado-membro atinente à matéria. ${ }^{95}$

${ }^{91}$ UNIÃO EUROPEIA. Directiva 76/207/CEE do Conselho, de 9 de fevereiro de 1976, relativa à concretização do princípio da igualdade de tratamento entre homens e mulheres no que se refere ao acesso ao emprego, à formação e promoção profissionais e às condições de trabalho. Disponível em: <http://eur-lex.europa.eu/LexUriServ/LexUriServ.do?uri=CELEX:31976L0207:PT:HTML〉. Acesso em: 4 dez. 2012.

${ }^{92}$ UNIÃO EUROPEIA. Directiva 86/613/CEE do Conselho, de 11 de dezembro de 1986 relativa à aplicação do princípio da igualdade de tratamento entre homens e mulheres que exerçam uma actividade independente incluindo a actividade agrícola, bem como à protecção da maternidade. Disponível em: <http://eur-lex.europa.eu/lexuriserv/lexuriserv.do?uri=celex:3198610613:pt:html>. Acesso em: 4 dez. 2012.

${ }^{93}$ UNIÃO EUROPEIA. Council Directive 2000/43/EC of 29 June 2000, implementing the principle of equal treatment between persons irrespective of racial or ethnic origin. Disponível em: <http://eurlex.europa.eu/LexUriServ/LexUriServ.do?uri=OJ:L:2000:180:0022:0026:en:PDF>. Acesso em: 5 dez. 2012.

${ }^{94}$ UNIÃO EUROPEIA. Directiva 2000/78/CE do Conselho, de 27 de novembro de 2000, que estabelece um quadro geral de igualdade de tratamento no emprego e na actividade profissional. Disponível em: <http://eur-lex.europa.eu/LexUriServ/LexUriServ.do?uri=CELEX:32000L0078:pt:HTML〉. Acesso em: 5 dez. 2012. 
Apontando de forma cristalina o interesse em ações positivas e medidas específicas, a Diretiva assegura que o princípio da igualdade de tratamento não obsta a que os Estadosmembros mantenham ou adotem medidas específicas destinadas a prevenir ou compensar desvantagens relacionadas com qualquer dos motivos de discriminação, e, ainda, não afeta o direito dos Estados-membros de manter ou adotar disposições em matéria de proteção da saúde e da segurança no local de trabalho ou medidas destinadas a criar ou a manter disposições ou facilidades para salvaguardar ou fomentar a sua inserção no mundo do trabalho.

Apesar das Diretivas ora apontadas, o Conselho da UE publicou inúmeras Recomendações afetas ao tema do presente trabalho. Dentre elas destaca-se a Recomendação n. 86/379/CEE, de 24 de julho de 1986, sobre o emprego de deficientes na Comunidade. Assim sendo, o texto recomenda aos Estados-membros que tomem todas as medidas apropriadas para assegurar aos deficientes uma igualdade de oportunidades em matéria de emprego e formação profissional, incluindo não só a formação inicial e o primeiro emprego, mas também a reabilitação e a reinserção. ${ }^{96}$

Nota-se que foram adotadas inúmeras medidas em prol da inclusão das pessoas com deficiências; perfilhando no mesmo caminho, ventila-se a Carta Comunitária dos Direitos Sociais Fundamentais dos Trabalhadores, de 1989, segundo a qual todas as pessoas deficientes, quaisquer que sejam a origem e a natureza da sua deficiência, devem se beneficiar de medidas adicionais concretas tendentes a favorecer a sua integração profissional e social. Referidas medidas de melhoria devem aplicar-se à formação profissional, à ergonomia, à acessibilidade, à mobilidade, aos meios de transporte e à habitação, em função das capacidades dos interessados. ${ }^{97}$

Neste ponto, destacam-se também a Resolução do Conselho e dos Ministros da

\footnotetext{
${ }^{95}$ UNIÃO EUROPEIA. Directiva 2000/78/CE. Op. cit.

${ }^{96}$ UNIÃO EUROPEIA. Recomendação 86/379/CEE do Conselho, de 24 de julho de 1986 sobre o emprego de deficientes na Comunidade. Disponível em: <http://eur-lex.europa.eu/LexUriServ/ LexUriServ.do?uri=CELEX:31986h0379:PT:HTML>. Acesso em: 5 dez. 2012.

${ }^{97}$ UNIÃO EUROPEIA. Carta Comunitária dos Direitos Sociais Fundamentais dos Trabalhadores. Disponível em: 〈http://ftp.infoeuropa.eurocid.pt/database/000043001-000044000/000043646.pdf〉. Acesso em: 5 dez. 2012.
} 
Educação de 31 de maio de $1990,{ }^{98}$ que aborda a integração das crianças e dos jovens deficientes no sistema de ensino regular; a Resolução do Conselho e dos Representantes dos Governos dos Estados-membros de 20 de dezembro de $1996^{99}$ e a Resolução do Conselho de 17 de junho de $1999,{ }^{100}$ ambas sobre a igualdade de oportunidades de emprego para as pessoas deficientes; a Resolução do Conselho de 5 de maio de $2003{ }^{101}$ relativa à igualdade de oportunidades em matéria de educação e formação de alunos e estudantes com deficiência; a Resolução do Conselho de 6 de maio de 2003, ${ }^{102}$ sobre o acesso das pessoas com deficiência às infraestruturas e atividades culturais; a Resolução do Conselho de 15 de julho de 2003, ${ }^{103}$ relativa à promoção do emprego e da integração social das pessoas com deficiência; e a Resolução do Conselho da União Europeia e dos Representantes dos Governos dos Estados-membros de 17 de março de 2008, ${ }^{104}$ sobre a situação das pessoas com deficiência na UE.

Dentre as Resoluções ora indicadas, merece destaque a Resolução do Conselho de 17 de Junho de 1999, sobre a igualdade de oportunidades de emprego para pessoas com deficiência. No referido texto, o Conselho reconhece os importantes esforços realizados e planeados pelos Estados-membros no sentido de elaborar e implementar políticas

\footnotetext{
${ }^{98}$ UNIÃO EUROPEIA. Resolução do Conselho e dos Ministros da Educação Reunidos em Conselho em 31 de maio de 1990 relativa à integração das crianças e dos jovens deficientes no sistema de ensino regular. Disponível em: <http://eur-lex.europa.eu/LexUriServ/LexUriServ.do? uri=OJ:C:1990:162:0002:0003:PT:PDF>. Acesso em: 5 dez. 2012.

${ }^{99}$ UNIÃO EUROPEIA. Resolução do Conselho e dos representantes dos Governos dos EstadosMembros reunidos no Conselho de 20 de dezembro de 1996 sobre a igualdade de oportunidades para pessoas deficientes. Disponível em: <http://eur-lex.europa.eu/LexUriServ/LexUriServ.do? uri=CELEX:41997X0113:PT:HTML>. Acesso em: 5 dez. 2012.

${ }^{100}$ UNIÃO EUROPEIA. Resolução do Conselho, de 17 de junho de 1999, sobre a igualdade de oportunidades de emprego para pessoas com deficiência. Disponível em: <http://eur-lex.europa.eu/ LexUriServ/LexUriServ.do?uri=CELEX:31999Y0702(01):PT:HTML>. Acesso em: 5 dez. 2012.

${ }^{101}$ UNIÃO EUROPEIA. Resolução do Conselho de 5 de maio de 2003 relativa à igualdade de oportunidades em matéria de educação e formação de alunos e estudantes com deficiência. Disponível em: 〈http://eur-lex.europa.eu/LexUriServ/LexUriServ.do?uri=OJ:C:2003:134:0006:0007:PT:PDF>. Acesso em: 5 dez. 2012.

${ }^{102}$ UNIÃO EUROPEIA. Resolução do Conselho de 6 de maio de 2003, sobre o acesso das pessoas com deficiência às infraestruturas e actividades culturais. Disponível em: <http://eur-lex.europa.eu/ LexUriServ/LexUriServ.do?uri=CELEX:32003G0607(02):PT:HTML>. Acesso em: 5 dez. 2012.

${ }^{103}$ UNIÃO EUROPEIA. Resolução do Conselho de 15 de julho de 2003 relativa à promoção do emprego e da integração social das pessoas com deficiência. Disponível em: <http://eur-lex.europa.eu/ LexUriServ/LexUriServ.do?uri=CELEX:32003G0724(01):PT:HTML>. Acesso em: 5 dez. 2012.

${ }^{104}$ UNIÃO EUROPEIA. Resolução do Conselho da União Europeia e dos Representantes dos Governos dos Estados-Membros, reunidos no Conselho de 17 de março de 2008 sobre a situação das pessoas com deficiência na União Europeia. Disponível em: <http://eur-lex.europa.eu/ LexUriServ/LexUriServ.do?uri=CELEX:42008x0326(01):PT:HTML>. Acesso em: 5 dez. 2012.
} 
destinadas a integrar as pessoas com deficiência no mercado de trabalho, especialmente no âmbito da estratégia europeia para o emprego.

Nesta linha o Conselho sublinha que os planos nacionais de ação para o emprego constituem uma plataforma ampla, no âmbito da qual as referidas políticas devem ser reforçadas. Assim, os Estados-membros são convidados a:

a) Atribuir especial importância à promoção de oportunidades de emprego para pessoas com deficiência no âmbito das políticas nacionais de emprego e em colaboração com os parceiros sociais e organizações não governamentais de defesa dos interesses das pessoas com deficiência e a desenvolver políticas adequadas, tanto preventivas como ativas, para promover a sua inserção no mercado de trabalho no setor público e no setor privado, incluindo o auto-emprego;

b) Utilizar plenamente as possibilidades atuais e futuras dos Fundos estruturais europeus, designadamente do Fundo Social Europeu e das iniciativas comunitárias relevantes, para promover a igualdade de oportunidade de emprego para pessoas com deficiência; e

c) Neste contexto, prestar uma especial atenção às possibilidades oferecidas pelo desenvolvimento da sociedade da informação em termos de novas oportunidades de emprego e de novos desafios para as pessoas com deficiência. ${ }^{105}$

Ainda, a Resolução do Conselho da União Europeia e dos Representantes dos Governos dos Estados-membros de 17 de março de 2008, mais recente e extremamente merecedora de atenção, reconhece que as pessoas com deficiência são muitas vezes desfavorecidas e marginalizadas, especialmente no domínio do emprego; portanto, o insuficiente acesso ao mercado de trabalho pode levar a que as pessoas sejam colocadas em situações vulneráveis na sociedade e expostas a sérios riscos de discriminação, pobreza e exclusão social.

Buscando afastar os riscos da discriminação e da exclusão social da pessoa com deficiência, o texto da referida Resolução convida aos Estados-membros e à Comissão, de acordo com as respectivas competências, a assegurar:

105 UNIÃO EUROPEIA. Resolução do Conselho de 17 de junho de 1999 sobre a igualdade de
oportunidades de emprego para pessoas com deficiência. Disponível em:
<http://ec.europa.eu/employment_social/soc-prot/disable/ojc186/councilres_pt.pdf>. Acesso em: 5 dez. 2012. 
1. Que as pessoas com deficiência gozem plenamente dos seus direitos humanos, através das seguintes medidas:

a) ratificação, celebração e, em seguida, implementação da Convenção da ONU, incluindo soluções europeias partilhadas no contexto de uma abordagem coerente e coordenada para a implementação da Convenção da ONU;

b) desenvolvimento de uma política abrangente compreendendo todos os instrumentos adequados, tendo em vista a eliminação da discriminação e a integração das pessoas com deficiência na sociedade, com base numa abordagem centrada nos direitos humanos e na integração das questões relacionadas com a deficiência;

c) incitação das pessoas com deficiência a terem uma participação ativa na força de trabalho assegurando o desenvolvimento e a aplicação de medidas anti-discriminação, o apoio ativo e a remoção de obstáculos;

d) tratamento da questão da discriminação múltipla de que são vítimas as mulheres com deficiência e a ajuda a estas últimas, com vista ao seu pleno desenvolvimento, promoção e autonomização;

e) adoção de medidas que permitam que, na medida do possível, as pessoas com deficiência vivam de maneira independente, sejam incluídas na comunidade e tenham acesso a serviços de assistência e de apoio de qualidade;

f) reforço da integração das questões relacionadas com a deficiência, prosseguindo os esforços desenvolvidos pelos Estados-Membros para obrigar os organismos públicos a promoverem a igualdade de oportunidades para as pessoas com deficiência;

g) um maior apoio aos Estados-Membros e às comunidades regionais e locais no processo de desinstitucionalização, sempre que isso seja no melhor interesse das pessoas com deficiência;

h) análise das eventuais lacunas no atual quadro legislativo comunitário de proteção contra a discriminação, nomeadamente por motivos de deficiência, e o estudo de respostas adequadas e específicas;

i) reforço das capacidades a nível nacional e comunitário para recolher e analisar informações adequadas, incluindo dados estatísticos e de investigação, de acordo com as garantias jurídicas e as regras de protecção de dados. ${ }^{106}$

Assim sendo, notório é o empenho da UE em fixar critérios de respeito aos direitos fundamentais e sociais, bem como em buscar o afastamento de qualquer forma de discriminação em favor das minorias.

Por fim, a Carta de Direitos Fundamentais da União Europeia, aprovada em 7 de dezembro de 2000, reconhece um conjunto de direitos pessoais, cívicos, políticos, econômicos e sociais dos cidadãos e residentes na UE, incorporando-os no Direito

${ }^{106}$ UNIÃO EUROPEIA. Resolução do Conselho da União Europeia e dos Representantes dos Governos dos Estados-Membros, reunidos no Conselho de 17 de março de 2008. Op. cit. 
comunitário. Estes direitos encontram-se reagrupados em seis grandes capítulos: Dignidade, Liberdade, Igualdade, Solidariedade, Cidadania e Justiça.

O Conselho Europeu compilou em uma Carta os direitos fundamentais em vigor na UE. Assim sendo, a Carta abarca os direitos fundamentais próprios dos cidadãos da UE, bem como os direitos econômicos e sociais consagrados na Carta Social do Conselho da Europa e na Carta Comunitária dos Direitos Sociais Fundamentais dos Trabalhadores.

Neste contexto, observa-se que restaram reunidos em um único documento os direitos que anteriormente se encontravam dispersos por diversos instrumentos legislativos, sendo destacada a clareza aos direitos fundamentais e à segurança jurídica dentro da UE.

Desta feita, a Carta foi elaborada por uma convenção composta por um representante de cada país da UE e da Comissão Europeia, bem como por deputados do parlamento europeu e dos parlamentos nacionais. Foi formalmente adotada em Nice, em dezembro de 2000, pelo Parlamento Europeu, pelo Conselho Europeu e pela Comissão Europeia. Em dezembro de 2009, com a entrada em vigor do Tratado de Lisboa, a Carta foi investida de efeito jurídico vinculativo, à semelhança dos Tratados. ${ }^{107}$

Em um capítulo único, intitulado "Igualdade", o texto da Carta sublinha e destaca os princípios da não discriminação e os direitos das pessoas com deficiência, estipulando:

Artigo 21

Não discriminação

1. É proibida a discriminação em razão, designadamente, do sexo, raça, cor ou origem étnica ou social, características genéticas, língua, religião ou convicções, opiniões políticas ou outras, pertença a uma minoria nacional, riqueza, nascimento, deficiência, idade ou orientação sexual.

2. No âmbito de aplicação dos Tratados e sem prejuízo das suas disposições específicas, é proibida toda a discriminação em razão da nacionalidade.

[...]

Artigo 26.

Integração das pessoas com deficiência

A União reconhece e respeita o direito das pessoas com deficiência a

107 UNIÃO EUROPEIA. Carta dos Direitos Fundamentais. Disponível em: <http://europa.eu/ legislation_summaries/justice_freedom_security/combating_discrimination/133501_pt.htm>. Acesso em: 5 dez. 2012. 
beneficiarem de medidas destinadas a assegurar a sua autonomia, a sua integração social e profissional e a sua participação na vida da comunidade.

Assim sendo, da análise das Diretivas, Resoluções, Recomendações, entre outros, resta claro o interesse e o apoio despendidos pela UE na luta contra as diversas formas de discriminação da pessoa deficiente.

\subsection{A normatização da relação de emprego da pessoa com deficiência no Direito estrangeiro}

Assim como anteriormente observado nos capítulos sobre o panorama histórico e o aspecto da terminologia, apesar de o presente trabalho ter como escopo primordial o estudo da realidade social e o sistema normativo brasileiro, necessária uma análise comparativa com ordenamentos jurídicos estrangeiros e distintos, tendo em vista que o estudo da relação de emprego da pessoa com deficiência remete a inúmeros momentos históricos e movimentos de luta por direitos em diversos países do mundo.

Seguindo esse entendimento, analisar de forma comparativa a legislação estrangeira acarretará uma melhor compreensão das normas jurídicas brasileiras que versam sobre a matéria.

Buscando delimitar o campo de estudo comparativo sobre o tema, e considerando que o labor da pessoa com deficiência está diretamente vinculado ao princípio da igualdade e da não discriminação, forçoso o entendimento de que referido tema deveria ser tratado em todo texto Constitucional. Entretanto, ao analisar as Constituições que tratam sobre a matéria - que se contam em um número pouco expressivo — , serão destacadas a Lei Maior de Portugal, da Espanha, da Itália e do Peru, tendo em vista que norteiam inclusive suas respectivas legislações infraconstitucionais, em especial sobre o aspecto da proteção da pessoa com deficiência.

Desta feita, serão ponderados os regimes de cotas para os setores público e privado, os regimes com previsão de incentivos financeiros para os empregadores e, ainda, as 
legislações que preveem políticas de proibição da discriminação em relação à pessoa com deficiência.

\subsubsection{Portugal}

A Constituição portuguesa, ${ }^{108}$ aprovada em 2 de abril de 1976 pela Assembleia Constituinte, é a lei suprema do país, sendo certo que consagra os direitos fundamentais dos cidadãos, os princípios essenciais por que se rege o Estado português e as grandes orientações políticas a que os seus órgãos devem obedecer, estabelecendo também as regras de organização do poder político.

Fundamentada no Estado Democrático de Direito, nota-se que o primeiro artigo da Constituição de Portugal aborda o tema de uma república soberana, baseada na dignidade da pessoa humana e na vontade popular, empenhada na construção de uma sociedade livre, justa e solidária.

Em seu artigo $8^{\circ}$, o texto Constitucional descreve de forma cristalina a influência do Direito Internacional:

1. As normas e os princípios de direito internacional geral ou comum fazem parte integrante do direito português.

2. As normas constantes de convenções internacionais regularmente ratificadas ou aprovadas vigoram na ordem interna após a sua publicação oficial e enquanto vincularem internacionalmente o Estado Português.

3. As normas emanadas dos órgãos competentes das organizações internacionais de que Portugal seja parte vigoram directamente na ordem interna, desde que tal se encontre estabelecido nos respectivos tratados constitutivos.

4. As disposições dos tratados que regem a União Europeia e as normas emanadas das suas instituições, no exercício das respectivas competências, são aplicáveis na ordem interna, nos termos definidos pelo direito da União, com respeito pelos princípios fundamentais do Estado de direito democrático. ${ }^{109}$

Portanto, as disposições referentes às políticas públicas, conforme requisitos

108 PORTUGal. Constituição da República Portuguesa, de 2 de abril de 1976. Disponível em: <http://www.tribunalconstitucional.pt/tc/crp.html>. Acesso em: 7 dez. 2012.

${ }^{109}$ Ibidem. 
mínimos fixados pela União Europeia, tornam-se lei no Estado português, destacando-se assim o valor atribuído aos direitos fundamentais.

Perfilhando neste mesmo caminho, a Constituição prevê de forma pontual quais as tarefas fundamentais do Estado português, quais sejam:

a) Garantir a independência nacional e criar as condições políticas, económicas, sociais e culturais que a promovam;

b) Garantir os direitos e liberdades fundamentais e o respeito pelos princípios do Estado de direito democrático;

c) Defender a democracia política, assegurar e incentivar a participação democrática dos cidadãos na resolução dos problemas nacionais;

d) Promover o bem-estar e a qualidade de vida do povo e a igualdade real entre os portugueses, bem como a efectivação dos direitos económicos, sociais, culturais e ambientais, mediante a transformação e modernização das estruturas económicas e sociais;

e) Proteger e valorizar o património cultural do povo português, defender a natureza e o ambiente, preservar os recursos naturais e assegurar um correcto ordenamento do território;

f) Assegurar o ensino e a valorização permanente, defender o uso e promover a difusão internacional da língua portuguesa;

g) Promover o desenvolvimento harmonioso de todo o território nacional, tendo em conta, designadamente, o carácter ultraperiférico dos arquipélagos dos Açores e da Madeira;

h) Promover a igualdade entre homens e mulheres.

Assim sendo, identifica-se como característica preponderante a observância do tratamento igualitário entre todas as pessoas, sendo utilizada, inclusive, a expressão “igualdade real”, assegurando a igualdade quanto à dignidade (bens da vida) e a igualdade de direitos (perante a lei). Referido aspecto resta ainda mais enfatizado no quanto disposto no artigo 13 da mencionada Carta Maior:

1. Todos os cidadãos têm a mesma dignidade social e são iguais perante a lei.

2. Ninguém pode ser privilegiado, beneficiado, prejudicado, privado de qualquer direito ou isento de qualquer dever em razão de ascendência, sexo, raça, língua, território de origem, religião, convicções políticas ou ideológicas, instrução, situação económica, condição social ou orientação sexual. ${ }^{110}$

O desejo de igualdade domina intensamente a vontade constitucional portuguesa, e

${ }^{110}$ PORTUGAL. Constituição da República Portuguesa. Op. cit. 
certamente acolhe a pessoa com deficiência, embora não esteja expressamente mencionada no item 2 do referido artigo. Explique-se que a lista, dele constante, mostra-se meramente exemplificativa. ${ }^{111}$

Nesta senda, impondo-se ao Estado políticas de pleno emprego, o artigo 58 trata sobre a universalidade do Direito do Trabalho:

1. Todos têm direito ao trabalho.

2. Para assegurar o direito ao trabalho, incumbe ao Estado promover:

a) A execução de políticas de pleno emprego;

b) A igualdade de oportunidades na escolha da profissão ou género de trabalho e condições para que não seja vedado ou limitado, em função do sexo, o acesso a quaisquer cargos, trabalho ou categorias profissionais;

c) A formação cultural e técnica e a valorização profissional dos trabalhadores.

Contudo, o corolário constitucional do direito das pessoas com deficiência resta concretizado através do quanto disposto no artigo 71 do Texto Constitucional:

1. Os cidadãos portadores de deficiência física ou mental gozam plenamente dos direitos e estão sujeitos aos deveres consignados na Constituição, com ressalva do exercício ou do cumprimento daqueles para os quais se encontrem incapacitados.

2. O Estado obriga-se a realizar uma política nacional de prevenção e de tratamento, reabilitação e integração dos cidadãos portadores de deficiência e de apoio às suas famílias, a desenvolver uma pedagogia que sensibilize a sociedade quanto aos deveres de respeito e solidariedade para com eles e a assumir o encargo da efectiva realização dos seus direitos, sem prejuízo dos direitos e deveres dos pais ou tutores.

3. O Estado apoia as organizações de cidadãos portadores de deficiência. ${ }^{112}$

Da leitura do Texto Constitucional, atenta-se para uma posição inclusiva no tocante à pessoa com deficiência, tendo em vista que foram outorgados a esta todos os direitos e deveres dos demais cidadãos plenos. Dessa maneira, impulsiona-se a ação estatal para que tais direitos sejam efetivos.

Traçando uma continuidade de reconhecimentos de direitos, o artigo 74 da

${ }^{111}$ FONSECA, Ricardo Tadeu Marques da. O trabalho da pessoa com deficiência. Op. cit., p. 96.

${ }^{112}$ PORTUGAL. Constituição da República Portuguesa. Op. cit. 
Constituição de Portugal trata sobre a educação, assegurando inclusive o acesso das pessoas com deficiência às escolas regulares e ao ensino especial, bem como a oficialização da língua gestual portuguesa enquanto expressão cultural e instrumento de acesso à educação e à igualdade de oportunidades.

Considerando que o artigo 71 da Constituição de Portugal atribui ao Estado a obrigação de realizar uma política nacional de prevenção e de tratamento, reabilitação e integração dos cidadãos com deficiência, cumpre ao Estado a responsabilidade de criar e coordenar as regras e as condições que permitam dar cumprimento àquelas atribuições e sensibilizar toda a sociedade para a sua efetivação.

Perfilhando neste caminho, o Decreto-Lei n. 29 , de 3 de fevereiro de $2001,{ }^{113}$ fixa a cota de $5 \%$ de vagas em todos os concursos públicos com no mínimo dez postos abertos. Nos concursos com quantidade de cargos inferior a dez, mas superior ou igual a três, garante-se a reserva de uma vaga para o candidato com deficiência. E, ainda, em concursos que ofereçam uma ou duas colocações ao candidato com deficiência, em situação de igualdade em classificação, concede-se o direito de preferência, que prevalece sobre qualquer outra preferência ou disposição legal. Assinala-se a exceção, tão somente, aos concursos referentes às carreiras com funções de natureza policial das forças e serviços de segurança e do Corpo da Guarda Prisional, pois nestes casos não se aceitam pessoas com deficiências. ${ }^{114}$

Enfim, a recente Lei n. 38, de 18 de agosto de 2004, ${ }^{115}$ define as bases gerais do regime jurídico da prevenção, habilitação, reabilitação e participação da pessoa com deficiência.

A referida lei prevê o conceito de pessoa com deficiência, considerando pessoa com deficiência aquela que, por motivo de perda ou anomalia, congênita ou adquirida, de

\footnotetext{
113 PORTUGAL. Decreto-Lei n. 29/2001 de 3 de fevereiro. Disponível em: <http://www.dgap.gov.pt/upload/Legis/2001_dl_29_03_02.pdf>. Acesso em: 7 dez. 2012.

${ }_{114}^{114}$ COSTA, Sandra Morais de Brito. Op. cit., p. 99.

${ }^{115}$ PORTUGAL. Bases gerais do regime jurídico da prevenção, habilitação, reabilitação e participação da pessoa com deficiência: Lei n. 38/2004, de 18 de agosto. Disponível em: <http://www.idesporto.pt/data/docs/legislacao/doc05_052.pdf>. Acesso em: 7 dez. 2012.
} 
funções ou de estruturas do corpo, incluindo as funções psicológicas, apresente dificuldades específicas suscetíveis de, em conjugação com os fatores do meio, limitar ou dificultar a atividade e a participação em condições de igualdade com as demais pessoas.

Salienta-se que o capítulo II da lei trata especificamente dos princípios fundamentais que pautam a política referente às pessoas com deficiências (princípios da singularidade, da cidadania, da não discriminação, da autonomia, da informação, da participação, da globalidade, da qualidade, do primado da responsabilidade pública, da transversalidade, da cooperação e da solidariedade).

A citada norma prevê a promoção, pelo Estado, de medidas que possibilitem evitar, eliminar ou atenuar as consequências da deficiência, em especial através de ações relativas: a) à acessibilidade; b) à sinistralidade (em especial resultantes de acidentes laborais, domésticos e de trânsito); c) ao consumo de substâncias que afetem a saúde, em especial o álcool, as drogas e o tabaco; d) aos hábitos alimentares; e) aos cuidados pré e pós-natais; f) à segurança, à higiene e à saúde no trabalho.

Segundo o texto da lei, a habilitação e a reabilitação são constituídas pelas medidas, nomeadamente nos domínios do emprego, trabalho e formação, consumo, segurança social, saúde, habitação e urbanismo, transportes, educação e ensino, cultura e ciência, sistema fiscal e desporto, que tenham em vista a aprendizagem e o desenvolvimento de aptidões, a autonomia e a qualidade de vida da pessoa com deficiência.

Nesse contexto, a lei determina que o Estado tem o dever de fomentar e apoiar o recurso ao autoemprego, o teletrabalho, o trabalho a tempo parcial e o trabalho em domicílio. A lei dispõe ainda sobre a implementação do sistema de cotas, de acordo com o quanto disposto no artigo 28 , in verbis:

1 - As empresas devem, tendo em conta a sua dimensão, contratar pessoas com deficiência, mediante contrato de trabalho ou de prestação de serviço, em número até $2 \%$ do total de trabalhadores.

2 - O disposto no número anterior pode ser aplicável a outras entidades empregadoras nos termos a regulamentar. 
3 - A Administração Pública deve proceder à contratação de pessoas com deficiência em percentagem igual ou superior a $5 \% .{ }^{116}$

Considerando que a lei em deslinde não prevê qualquer penalidade para as empresas que deixarem de observar o disposto no artigo acima mencionado e que, ao final, a lei determina que cumpre ao governo a aprovação das normas necessárias ao desenvolvimento da lei, o regime de cotas tem natureza de norma programada, ficando dependente de legislação que o regule. ${ }^{117}$

\subsubsection{Espanha}

Sancionada em 27 de dezembro de 1978, a Constituição Espanhola abarca em seus artigos $9^{\circ}, 14,40,41$ e 49 os direitos da pessoa com deficiência.

Segundo o disposto no artigo $9^{\circ}$ da Constituição da Espanha, todos os cidadãos estão sujeitos ao cumprimento do quanto previsto na Constituição e nas leis comuns, sendo projetada inclusive uma postura efetiva do Estado com intuito de proporcionar a igualdade real. Neste sentido, cumpre ao Estado remover os obstáculos físicos, comportamentais, políticos e econômicos para que todos os indivíduos possam usufruir da igualdade de direitos e deveres.

Desta forma, o referido artigo trata inclusive sobre o princípio da legalidade, da hierarquia das leis, da irretroatividade e da publicidade das normas, a saber:

Articulo 9

1. Los ciudadanos y los poderes públicos están sujetos a la Constitución y al resto del ordenamiento jurídico.

2. Corresponde a los poderes públicos promover las condiciones para que la libertad y la igualdad del individuo y de los grupos en que se integra sean reales y efectivas; remover los obstáculos que impidan o dificulten su plenitud y facilitar la participación de todos los ciudadanos en la vida política, económica, cultural y social.

3. La Constitución garantiza el principio de legalidad, la jerarquía normativa, la publicidad de las normas, la irretroactividad de las disposiciones sancionadoras no favorables o restrictivas de derechos

\footnotetext{
${ }^{116}$ PORTUGAL. Bases gerais do regime jurídico da prevenção, habilitação, reabilitação e participação da pessoa com deficiência. Op. cit.

${ }^{117}$ GOLDFARB, Cibelle Linero. Op. cit., p. 65.
} 
individuales, la seguridad jurídica, la responsabilidad y la interdicción de la arbitrariedad de los poderes públicos. ${ }^{118}$

O artigo 14 da Constituição da Espanha reafirma o princípio da igualdade, tendo em vista que trata sobre a igualdade formal de todos os cidadãos perante a lei, bem como dispõem:

\begin{abstract}
Articulo 14
Los españoles son iguales ante la ley, sin que pueda prevalecer discriminación alguna por razón de nacimiento, raza, sexo, religión, opinión o cualquier otra condición o circunstancia personal o social. ${ }^{119}$
\end{abstract}

Os artigos 40 e 41, em especial, refletem os direitos trabalhistas do povo espanhol e o artigo 49 ventila a preocupação imediata do Estado no tocante ao trabalho da pessoa com deficiência:

\begin{abstract}
Articulo 40
1. Los poderes públicos promoverán las condiciones favorables para el progreso social y económico y para una distribución de la renta regional y personal más equitativa, en el marco de una política de estabilidad económica. De manera especial realizarán una política orientada al pleno empleo.

2. Asimismo, los poderes públicos fomentarán una política que garantice la formación y readaptación profesionales; velarán por la seguridad e higiene en el trabajo y garantizaran el descanso necesario, mediante la limitación de la jornada laboral, las vacaciones periódicas retribuidas y la promoción de centros adecuados.

Articulo 41

Los poderes públicos mantendrán un régimen público de Seguridad Social para todos los ciudadanos, que garantice la asistencia y prestaciones sociales suficientes ante situaciones de necesidad, especialmente en caso de desempleo. La asistencia y prestaciones complementarias serán libres.

[...]

Articulo 49

Los poderes públicos realizarán una política de previsión, tratamiento, rehabilitación e integración de los disminuidos físicos, sensoriales y psíquicos, a los que prestarán la atención especializada que requieran y los ampararán especialmente para el disfrute de los derechos que este Título otorga a todos los ciudadanos. ${ }^{120}$
\end{abstract}

118 ESPANHA. Constitución Española. Disponível em: <http://www.boe.es/boe/dias/1978/12/29/pdfs/ A29313-29424.pdf>. Acesso em: 6 dez. 2012.

${ }^{119}$ ESPANHA. Constitución Española. Op. cit.

${ }^{120}$ Ibidem. 
No tocante às normas ordinárias, imperioso mencionar a Ley de Integración Social de los Minusválidos - LISMI (Lei n. 13/1982), ${ }^{121}$ que pretende, entre outros objetivos, impulsar e fomentar a integração laboral da pessoa com deficiência. Referida lei estabelece que as empresas públicas e privadas com mais de cinquenta empregados deverão contratar ao menos $2 \%$ de trabalhadores com deficiência.

Contudo, apesar da existência da norma ora indicada, poucas empresas concretizam o cumprimento legal. Portanto, com o intuito de facilitar o cumprimento da destacada obrigação, em 2000, significativas alterações na legislação espanhola passaram a permitir que as empresas públicas e privadas, de maneira excepcional, deixassem de preencher a cota compulsória (total ou parcial), desde que não houvesse candidato para a vaga. ${ }^{122}$

Desta feita, nota-se que a Espanha, assim como o Brasil, possui um sistema de cotas compulsórias.

Ademais, segundo o Decreto Real n. 1/95, que contempla o Estatuto dos Trabalhadores da Espanha, serão concedidos incentivos fiscais no importe de $50 \%$ das cotas patronais da seguridade social respectiva às empresas que contratarem pessoas com deficiências em tempo integral e/ou para formação profissional. ${ }^{123}$

Para o Direito espanhol, segundo o entendimento do tribunal constitucional, o empregador não pode simplesmente despedir sem justa causa um trabalhador deficiente, ao passo que o prejudicado poderá intentar uma reinvindicação judicial para pleitear sua estabilidade. Assim sendo, as garantias de emprego da pessoa com deficiência destinam-se a superar obstáculos e promover o reconhecimento e efetivação do direito constitucional.

Por derradeiro, muito embora existam incentivos fiscais e subsídios para que as empresas contratem empregados com deficiência, inúmeros empregadores não preenchem a cota estipulada, tendo em vista, primeiramente, a ineficaz cobrança governamental e a

\footnotetext{
121 ESPANHA. Ley de Integración Social de los Minusválidos. Disponível em: <http://www.feaps.org/archivo/centro-documental/doc_download/330-lismi-ley-131982-de-integracionsocial-de-los-minusvalidos.html>. Acesso em: 6 dez. 2012.

${ }^{122}$ COSTA, Sandra Morais de Brito. Op. cit., p. 92.

${ }^{123}$ Ibidem, p. 94.
} 
aplicação de penas brandas pelas infrações praticadas, e, ainda, o fato de a lei apontar inúmeras lacunas utilizadas pelos empregadores em prol de seus interesses. ${ }^{124}$

\subsubsection{Itália}

Da a análise da Constituição italiana, alicerce da democracia do país, promulgada em 27 de dezembro de 1947, observa-se que restam consagrados os princípios da igualdade e da dignidade de todos os cidadãos, bem como a eliminação de todo e qualquer preconceito de sexo, raça, língua, religião, opinião pública e condição pessoal e social.

Neste sentido, o artigo $3^{\circ}$ da referida Carta Constitucional prevê:

Tutti i cittadini hanno pari dignità sociale e sono eguali davanti alla legge, senza distinzione di sesso, di razza, di lingua, di religion, di opinion politiche, di condizione personali e sociali.

$\grave{E}$ compito dell Republica rimuovere gli ostacoli di ordine economico e sociale, che, limitando di fato la libertà e l'eguaglianza dei cittadini, impediscono il pieno sviluppo della persona umana e l'effettiva partecipazione di tutti $i$ lavoratori all'organizzazione politica, economica e sociale del Paese. ${ }^{125}$

Referido artigo, em sua segunda parte, destaca ser dever do Estado italiano remover os obstáculos de ordem econômica e social que impedem o pleno desenvolvimento da pessoa e a efetiva participação de todos os trabalhadores na organização política, econômica e social do país.

Neste caminho, o artigo $4^{\circ}$ da mencionada Carta Constitucional afirma o reconhecimento do direito ao trabalho de todos os cidadãos, e, ainda, outorga a cada cidadão o dever de exercer uma atividade ou uma função que contribua para o progresso material ou espiritual da sociedade.

Ainda, o artigo 38 da Constituição italiana aborda de forma direta o direito à educação e ao encaminhamento profissional da pessoa com deficiência, in verbis:

\footnotetext{
${ }^{124}$ LOPES, Gláucia Gomes Vergara. Op. cit., p. 41.

125 ITÁLIA. La Costituzione. Disponível em: <http://www.quirinale.it/qrnw/statico/costituzione/ costituzione.htm>. Acesso em: $10 \mathrm{dez} .2012$.
} 
Ogni cittadino inabile al lavoro e sprovvisto dei mezzi necessari per vivere ha diritto al mantenimento e all'assistenza sociale.

I lavoratori hanno diritto che siano preveduti ed assicurati mezzi adeguati alle loro esigenze di vita in caso di infortunio, malattia, invalidità e vecchiaia, disoccupazione involontaria.

Gli inabili ed i minorati hanno diritto all'avviamento professionale.

Ai compiti previsti in questo articolo provvedono oragbi ed istituti predisposti o integrati dallo Stato.

L'assistenza privata è libera. ${ }^{126}$

De acordo com o disposto no referido artigo supracitado, todo cidadão, impossibilitado de trabalhar e desprovido dos recursos necessários para viver, tem direito ao seu sustento e à assistência social. E, ainda, os incapacitados e os deficientes têm direito à educação e ao encaminhamento profissional.

Na Itália existe o sistema colocação obrigatória, regulado através da Lei n. 482, de 2 de abril de 1968. Esta lei, com fins de solidariedade social e para ensejar a inserção na vida laborativa de algumas categorias especiais de pessoas, estabelece que os empregadores públicos e privados que tiverem a seu serviço mais de 50 empregados, devem admitir pessoas com deficiências na proporção de $7 \%$ de seus trabalhadores. No caso das empresas com 36 a 50 trabalhadores, devem ser contratadas duas pessoas com deficiência, e se a empresa possuir entre 15 e 35 trabalhadores deve contratar uma pessoa com deficiência. ${ }^{127}$

A lei em apreço não impõe de maneira obrigatória o cumprimento da cota de 7\%, mas tão somente sugere, o que implica em uma postura construtiva, progressiva, proativa do Estado e da sociedade, no sentindo de buscar a inclusão das pessoas com deficiências, cuidando-se de inseri-las em atividades efetivamente produtivas e satisfatórias ao empregador e ao trabalhador. ${ }^{128}$

\subsubsection{Peru}

A Constituição peruana de 1993 , de acordo com o artigo $7^{\circ}$, declara que a pessoa incapacitada para velar por si própria por causa de uma deficiência física ou mental tem

\footnotetext{
${ }^{126}$ ITÁLIA. La Costituzione. Op. cit.

${ }^{127}$ FONSECA, Ricardo Tadeu Marques da. O trabalho da pessoa com deficiência... Op. cit., p. 108.
} 
direito ao respeito de sua dignidade e a um regime legal de proteção, atenção, readaptação e seguridade, in verbis:

Artículo $7^{\circ}$. Todos tienen derecho a la protección de su salud, la del medio familiar y la de la comunidad así como el deber de contribuir a su promoción y defensa. La persona incapacitada para velar por sí misma a causa de una deficiencia física o mental tiene derecho al respeto de su dignidad y a un régimen legal de protección, atención, readaptación y seguridad. $^{129}$

Caminhando no mesmo entendimento, o artigo 23 da mesma Carta Constitucional assegura o direito ao trabalho da pessoa com deficiência:

Artículo $23^{\circ}$. El trabajo, en sus diversas modalidades, es objeto de atención prioritaria del Estado, el cual protege especialmente a la madre, al menor de edad y al impedido que trabajan.

El Estado promueve condiciones para el progreso social y económico, en especial mediante políticas de fomento del empleo productivo y de educación para el trabajo.

Ninguna relación laboral puede limitar el ejercicio de los derechos constitucionales, ni desconocer o rebajar la dignidad del trabajador.

Nadie está obligado a prestar trabajo sin retribución o sin su libre consentimiento. ${ }^{130}$

Ainda, de acordo com a Lei Geral da Pessoa com Deficiência, o trabalho da pessoa deficiente é tratado de forma específica, viabilizando a integração na vida econômica da nação, sendo estendida a integralidade dos direitos laborais e previdenciários. Outro ponto que merece destaque na referida Lei é a proibição de discriminação no emprego no tocante ao acesso, remuneração e progresso, sendo estabelecida, ainda, a concessão de benefícios para a pessoa deficiente e para as empresas que as contratem. Desta forma, e de maneira exemplificativa, micros e pequenas empresas que contratem pessoas com deficiências podem obter créditos preferenciais e financiamentos de organismos financeiros nacionais e internacionais, assim como as empresas públicas e privadas que empregarem pessoas com deficiências podem deduzir da renda bruta uma percentagem das remunerações pagas a estas pessoas, a ser fixada pelo Ministério da Economia. ${ }^{131}$

\footnotetext{
${ }^{128}$ FONSECA, Ricardo Tadeu Marques da. O trabalho da pessoa com deficiência... Op. cit., p. 109.

129 PERU. Constitución Política del Perú. Disponível em: <http://www.tc.gob.pe/legconperu/ constitucion.html>. Acesso em: $10 \mathrm{dez} .2012$.

${ }^{130}$ Ibidem.

${ }^{131}$ FONSECA, Ricardo Tadeu Marques da. O trabalho da pessoa com deficiência... Op. cit., p. 117.
} 
Inúmeros países da América Latina, da Europa, entre outros, regulam e protegem o trabalho da pessoa com deficiência, bem como a sua inclusão no mercado de trabalho; contudo, não foram observadas referências expressas no texto das suas respectivas Constituições, razão pela qual não foram abordadas pelo presente trabalho. 


\section{A EVOLUÇÃO DO ORDENAMENTO JURÍDICO BRASILEIRO: OS DIREITOS DA PESSOA COM DEFICIÊNCIA}

O presente capítulo buscará discorrer sobre a evolução do ordenamento jurídico brasileiro diante do tema em tela, ponderando a aplicação objetiva da Carta Magna e da Lei que dispõe sobre os benefícios da Previdência Social e sobre a inserção do sistema de cotas do setor privado (Lei n. 8.213/91), o papel, como órgão fiscalizador, do Ministério Público do Trabalho (MPT) e do Ministério do Trabalho e Emprego (MTE), e ainda, quais seriam os mecanismos e incentivos de cumprimento da legislação. Dentro deste exame, será traçada, inclusive, uma abordagem ampla sobre as ações afirmativas e suas peculiaridades, em especial no Brasil.

Nesta seara, buscar-se-á uma interpretação ampla da legislação vigente, no tocante à inclusão de pessoas ou "padrões" não contemplados na Lei n. 8.213/91 e no Decreto n. 3.298/99 para fins de preenchimento de cotas, como, por exemplo, pessoas queimadas, com surdez unilateral, visão monocular, lábio leporino e/ou fenda palatina, diabéticas insulino-dependentes, ex-cancerosas e obesas.

Nota-se que a legislação não prevê a inclusão dessa "deficiência invisível”, mas a exclusão no mercado de trabalho desta parcela da população é notória, sendo certo que encontram inúmeras dificuldades nos processos regulares de seleção.

Assim sendo, o presente capítulo trará uma abordagem ampla da expressão "inclusão" através da atividade profissional, elevando o respeito aos direitos e garantias do indivíduo e afastando qualquer imposição de condição, possibilidade ou padrão.

\subsection{Constituição Federal de 1988}

Imperioso mencionar que a primeira menção constitucional expressa sobre a pessoa com deficiência encontra-se na Constituição de 1967, em razão da Emenda n. 1/1969, que modificou o texto do artigo $175, \S 4^{\circ}$, in verbis: 
Art. 175. A família é constituída pelo casamento e terá direito à proteção dos Podêres Públicos.

[...]

$\S 4^{\circ}$ Lei especial disporá sôbre a assistência à maternidade, à infância e à adolescência e sôbre a educação de excepcionais. ${ }^{132}$

Segundo o entendimento de Manoel Gonçalves Ferreira Filho, o conceito de excepcional mencionado no referido artigo abrange "aqueles que por motivos físicos ou mentais se encontram em situação de inferioridade em relação aos chamados "normais"”. 133

E, ainda, Pontes de Miranda destaca que, neste contexto, “excepcionais está, aí, por pessoas que, por faltas, ou defeitos físicos ou psíquicos, ou por procedência anormal (nascido, por exemplo, em meio social perigoso), precisam de assistência”. ${ }^{134}$

Ato contínuo, a Emenda Constitucional n. 12, de 17 de outubro de 1978, introduziu no ordenamento jurídico constitucional a proteção ao deficiente quanto a educação, assistência, reabilitação e reinserção na vida econômica e social, e, ainda, abordou o princípio da não discriminação e a questão da acessibilidade da pessoa com deficiência aos edifícios e logradouros públicos.

\footnotetext{
Artigo único - É assegurado aos deficientes a melhoria de sua condição social e econômica especialmente mediante:

I - educação especial e gratuita;

II - assistência, reabilitação e reinserção na vida econômica e social do país;

III- proibição de discriminação, inclusive quanto à admissão ao trabalho ou ao serviço público e a salários;

IV - possibilidade de acesso a edifícios e logradouros públicos. ${ }^{135}$
}

\footnotetext{
132 BRASIL. Emenda Constitucional n. 1, de 17 de outubro de 1969. Disponível em: <http://www.planalto.gov.br/ccivil_03/constituicao/Emendas/Emc_anterior1988/emc01-69.htm>. Acesso em: $11 \mathrm{dez} .2012$.

${ }^{133}$ FERREIRA FILHO, Manoel Antonio. Comentários à Constituição Brasileira: Emenda Constitucional n . 1, de 17-10-1969, com as alterações introduzidas pelas Emendas Constitucionais até a de n. 27, de 27-111985. 6. ed. São Paulo: Saraiva, 1986, p. 702.

${ }^{134}$ MIRANDA, Pontes de. Comentários à Constituição de 1967: com a Emenda n. 1, de 1969. 2. ed., São Paulo: Revista dos Tribunais, 1972, t. 6 (arts. 160-200), p. 333.

135 BRASIL. Emenda Constitucional n. 12, de 17 de outubro de 1978. Disponível em: <https://www.planalto.gov.br/ccivil_03/constituicao/emendas/emc_anterior1988/emc12-78.htm>. Acesso em: 11 dez. 2012.
} 
Nota-se que, apesar da observância dos direitos relacionados às pessoas com deficiências através da Emenda Constitucional n. 12/78, poucas alterações foram observadas até a promulgação da Constituição de 1988.

As disposições elencadas na Constituição Federal, promulgada em 5 de outubro de 1988, merecem especial atenção. A mencionada Carta Maior foi um marco para os direitos sociais no Brasil, bem como cuidou de garantir o direito à igualdade de forma ampla e de proteger as pessoas em situações desvantajosas, seja por questões raciais, socioeconômicas ou em razão de alguma deficiência.

Conforme mencionado em capítulo anterior, a Constituição de 1988 abandonou o modelo assistencialista, anteriormente adotado, e passou a existir espaço para a integração e inclusão social da pessoa com deficiência.

A Carta Maior, em seu artigo $1^{\circ}$, elenca como fundamentos da República Federativa do Brasil: "I) a soberania; II) a cidadania; III) a dignidade da pessoa humana; IV) os valores sociais do trabalho e da livre-iniciativa; e V) a pluralismo político". ${ }^{136}$

E caminhando neste mesmo sentido, o artigo $3^{\circ}$ da Constituição de 1988, traça os seguintes objetivos:

I) construir uma sociedade livre, justa e solidária;

II) garantir o desenvolvimento nacional;

III) erradicar a pobreza e a marginalização e reduzir as desigualdades sociais e regionais;

IV) promover o bem de todos, sem preconceitos de origem, raça, sexo, cor, idade e quaisquer outras formas de discriminação. ${ }^{137}$

Portanto, da análise dos fundamentos e dos objetivos indicados na Constituição, resta incontestável o entendimento de um Estado ativo e compromissado em viabilizar uma vida digna para todos os cidadãos, sem exceção.

136 BRASIL. Constituição da República Federativa do Brasil de 1988. Disponível em: <http://www.planalto.gov.br/ccivil_03/constituicao/ConstituicaoCompilado.htm>. Acesso em: 11 dez. 2012. ${ }^{137}$ Ibidem. 
Assim, destaca-se o disposto no artigo $7^{\circ}$, inciso XXXI, da Magna Carta, que prevê de forma expressa o rol de direitos dos trabalhadores urbanos e rurais e a não discriminação da pessoa com deficiência:

Art. $7^{\circ}$ São direitos dos trabalhadores urbanos e rurais, além de outros que visem à melhoria de sua condição social:

$[\ldots]$

XXXI - proibição de qualquer discriminação no tocante a salário e critérios de admissão do trabalhador portador de deficiência. ${ }^{138}$

O doutrinador Paulo Eduardo Vieira de Oliveira, aborda o tema ventilado da seguinte maneira:

Assim o empregador que deixar de contratar candidato ao emprego ou dificultar a promoção, rebaixar salários ou deixar de conceder reajustes salariais, como, por exemplo, das pessoas portadoras de deficiência, em virtude de tal fato, estará sujeito às reparações tarifadas do direito do trabalho, além das decorrentes do dano pessoal causado ao candidato ao emprego ou ao empregado. ${ }^{139}$

No tocante à competência material e legislativa sobre a proteção e integração da pessoa com deficiência, a Constituição, em seus artigos 23 e 24, prevê, in verbis:

Art. 23. É competência comum da União, dos Estados, do Distrito Federal e dos Municípios:

[...]

II - cuidar da saúde e assistência pública, da proteção e garantia das pessoas portadoras de deficiência.

Art. 24. Compete à União, aos Estados e ao Distrito Federal legislar concorrentemente sobre:

$[\ldots]$

XIV - proteção e integração social das pessoas portadoras de deficiência. ${ }^{140}$

Seguindo o alinhamento do texto constitucional, a Lei n. 7.853, de 24 de outubro de 1989, tratou sobre o apoio à pessoa com deficiência, sua integração social, sobre a Coordenadoria Nacional para Integração da Pessoa Portadora de Deficiência - CORDE e

\footnotetext{
${ }^{138}$ BRASIL. Constituição de 1988. Op. cit.

${ }^{139}$ OLIVEIRA, Paulo Eduardo Vieira de. O dano pessoal no Direito do Trabalho. São Paulo: LTr, 2002, p. 115.

${ }^{140}$ BRASIL. Constituição de 1988. Op. cit.
} 
instituiu a tutela jurisdicional de interesses coletivos ou difusos dessas pessoas, disciplinando inclusive a atuação do Ministério Público. ${ }^{141}$

A referida Lei determina que o exercício dos direitos individuais e sociais da pessoa com deficiência dependerá das ações governamentais, bem como do empenho da sociedade, cumprindo ao Poder Público assegurar o direito à educação, à saúde, ao trabalho, ao lazer, à previdência social, ao amparo à infância e à maternidade.

Art. $2^{\circ}$ Ao Poder Público e seus órgãos cabe assegurar às pessoas portadoras de deficiência o pleno exercício de seus direitos básicos, inclusive dos direitos à educação, à saúde, ao trabalho, ao lazer, à previdência social, ao amparo à infância e à maternidade, e de outros que, decorrentes da Constituição e das leis, propiciem seu bem-estar pessoal, social e econômico.

Parágrafo único. Para o fim estabelecido no caput deste artigo, os órgãos e entidades da administração direta e indireta devem dispensar, no âmbito de sua competência e finalidade, aos assuntos objetos esta Lei, tratamento prioritário e adequado, tendente a viabilizar, sem prejuízo de outras, as seguintes medidas:

[...]

III - na área da formação profissional e do trabalho:

a) o apoio governamental à formação profissional, e a garantia de acesso aos serviços concernentes, inclusive aos cursos regulares voltados à formação profissional;

b) o empenho do Poder Público quanto ao surgimento e à manutenção de empregos, inclusive de tempo parcial, destinados às pessoas portadoras de deficiência que não tenham acesso aos empregos comuns;

c) a promoção de ações eficazes que propiciem a inserção, nos setores públicos e privado, de pessoas portadoras de deficiência;

d) a adoção de legislação específica que discipline a reserva de mercado de trabalho, em favor das pessoas portadoras de deficiência, nas entidades da Administração Pública e do setor privado, e que regulamente a organização de oficinas e congêneres integradas ao mercado de trabalho, e a situação, nelas, das pessoas portadoras de deficiência. ${ }^{142}$

No que diz respeito ao setor público, o artigo 37, inciso VIII, da Carta Maior é taxativo em dispor quanto à reserva de vagas:

Art. 37. A administração pública direta e indireta de qualquer dos Poderes da União, dos Estados, do Distrito Federal e dos Municípios

141 BRASIL. Lei n. 7.853, de $\mathbf{2 4}$ de outubro de 1989. Disponível em: <http://www.planalto.gov.br/ccivil_03/leis/L7853compilado.htm>. Acesso em: 22 dez. 2012.

${ }^{142}$ BRASIL. Constituição de 1988. Op. cit. 
obedecerá aos princípios de legalidade, impessoalidade, moralidade, publicidade e eficiência e, também, ao seguinte:

$[\ldots]$

VIII - a lei reservará percentual dos cargos e empregos públicos para as pessoas portadoras de deficiência e definirá os critérios de sua admissão. ${ }^{143}$

Cumpre destacar que, em 20 de dezembro de 1999, o Decreto n. 3.298, que regulamenta a Lei n. 7.853/89, consolidou as normas atinentes aos direitos das pessoas com deficiências. Referido Decreto aborda o conceito de deficiência, as competências do Conselho Nacional dos Direitos da Pessoa Portadora de Deficiência (CONADE) e da Coordenadoria para Integração da Pessoa Portadora de Deficiência (CORDE), e, ainda, dispõe de forma específica quanto à inscrição da pessoa com deficiência em concurso público, em situação de igualdade de condições com os demais candidatos, para provimento de cargo cujas atribuições sejam compatíveis com a deficiência de que é portadora.

Nota-se que o artigo 37, $\S 1^{\circ}$, do mencionado Decreto determina que o candidato com deficiência, em razão da necessária igualdade de condições, concorrerá a todas as vagas, sendo reservado no mínimo o percentual de 5\% em face da classificação obtida. E, ainda, caso a aplicação do percentual resulte em número fracionado, este deverá ser elevado até o primeiro número inteiro subsequente.

Portanto, para o acesso aos cargos públicos por meio de concurso o percentual reservado deverá ser de no mínimo $5 \%$ e, no máximo, $20 \%$ das vagas oferecidas, nos termos do artigo $5^{\circ}, \S 2^{\circ}$, da Lei n. 8.112/90, in verbis:

Art. $5^{\circ}$ São requisitos básicos para investidura em cargo público:

[...]

$\S 2^{\circ}$ Às pessoas portadoras de deficiência é assegurado o direito de se inscrever em concurso público para provimento de cargo cujas atribuições sejam compatíveis com a deficiência de que são portadoras; para tais pessoas serão reservadas até $20 \%$ (vinte por cento) das vagas oferecidas no concurso. ${ }^{144}$

${ }^{143}$ BRASIL. Constituição de 1988. Op. cit.

144 BRASIL. Lei n. 8.112, de 11 de dezembro de 1990. Disponível em: <http://www.planalto.gov.br/ccivil_03/leis/L8112compilado.htm〉. Acesso em: 12 dez. 2012. 
A legislação atinente ao tema determina duas exceções para a reserva de vagas no setor público, quais sejam:

Art. 38. Não se aplica o disposto no artigo anterior nos casos de
provimento de:
I - cargo em comissão ou função de confiança, de livre nomeação e
exoneração; e
II - cargo ou emprego público integrante de carreira que exija aptidão
plena do candidato. . $^{45}$

No tocante a compatibilidade entre o cargo e a deficiência do candidato, os órgãos públicos devem adotar as medidas necessárias para evitar qualquer discriminação fundada no descrédito com relação à capacidade da pessoa com deficiência. Deve ser observada a realização de exames médicos após a aprovação nas provas do concurso, não podendo ser obstado o direito de realizar a prova, e, ainda, se a deficiência for considerada incompatível com a função, a pessoa obstada do direito de assumir a vaga poderá exercer seu direito de recorrer. $^{146}$

Ainda neste contexto, cumpre destacar a controvérsia apontada quanto à reserva de vagas em concursos para ingresso na magistratura. O doutrinador Francisco Antonio de Oliveira caminha no entendimento de que, sendo os magistrados agentes políticos, o que difere conceitualmente de funcionário público, e, ainda, estando a magistratura regida pela Lei Complementar n. 35/79, não seria possível a aplicação do disposto na Lei n. 8.112/90, sendo certo que esta estaria destinada exclusivamente ao concurso de funcionários públicos. $^{147}$

Em sentido absolutamente diverso, cumpre mencionar o entendimento da doutrinadora Cristiane Maria Sbalqueiro Lopes, segundo o qual, não obstante os membros do Ministério Público e da magistratura tenham estatutos especiais pelos quais são regidos, não se pode excluir o dever de observância da norma constitucional, tendo em vista que o artigo 37 da Magna Carta vincula todos os poderes de todas as esferas da federação.

\footnotetext{
145 BRASIL. Decreto n. 3.298/1999. Op. cit.

${ }^{146}$ GOLDFARB, Cibelle Linero. Op. cit., p. 86.

${ }^{147}$ OLIVEIRA, Francisco Antonio. Do concurso a magistratura e a reserva de vagas para deficientes. Revista LTr. São Paulo, v. 67, n. 2, fev. 2003, p. 151.
} 
Portanto, o fato de tais instituições serem tuteladas por lei especial não afasta o cumprimento das regras constitucionais de caráter geral. ${ }^{148}$

No tocante às empresas públicas e às sociedades de economia mista, a reserva de vagas para a pessoa com deficiência deve observar o quanto disposto no artigo 37, inciso VIII, da Constituição Federal de 1988, bem como a Lei n. 8.112/90 e o Decreto n. 3.298/99.

Buscando pontuar todos os aspectos ventilados no texto da Carta Maior quanto à proteção da pessoa com deficiência, cumpre mencionar o quanto disposto no artigo 203, em seus incisos IV e V, a saber:

Art. 203. A assistência social será prestada a quem dela necessitar, independentemente de contribuição à seguridade social, e tem por objetivos:

[...]

IV - a habilitação e reabilitação das pessoas portadoras de deficiência e a promoção de sua integração à vida comunitária;

$\mathrm{V}$ - a garantia de um salário mínimo de benefício mensal à pessoa portadora de deficiência e ao idoso que comprovem não possuir meios de prover à própria manutenção ou de tê-la provida por sua família, conforme dispuser a lei. ${ }^{149}$

Nesta linha, quanto à habilitação e reabilitação da pessoa com deficiência, é possível atentar para um precioso avanço legislativo, tendo em vista que a legislação ordinária anterior abordava, tão somente, a readaptação e a reeducação de segurados que percebiam auxílio-doença, aposentados e pensionistas inválidos. ${ }^{150}$

A concessão do benefício assistencial, citado no artigo 203 da Constituição, é cabível independentemente de o beneficiário ter contribuído para o regime previdenciário, sendo devido, portanto, às pessoas com deficiências e aos idosos.

\footnotetext{
${ }^{148}$ LOPES, Cristiane Maria Sbalqueiro. Aplicação da legislação de reserva de vagas em concursos públicos como concretização político-jurídica do princípio da igualdade. Revista do Ministério Público do Trabalho. Brasília, ano 13, n. 25, mar. 2003, p. 26-27.

${ }^{149}$ BRASIL. Constituição de 1988. Op. cit.

${ }^{150}$ SILVA, Walküre Lopes Ribeiro da. Seguridade social e a pessoa portadora de deficiência: direitos da pessoa portadora de deficiência. Revista da Advocacia Pública \& Sociedade. São Paulo, ano 1, n. 1, 1997,
} 
O artigo 208, inciso III, da Constituição trata sobre a integração da pessoa deficiente nas escolas regulares de ensino, com intuito de afastar a discriminação e incentivar a socialização, in verbis:

Art. 208. O dever do Estado com a educação será efetivado mediante a garantia de:

[...]

III - atendimento educacional especializado aos portadores de deficiência, preferencialmente na rede regular de ensino. ${ }^{151}$

E, ainda, o artigo 227 da Magna Carta prevê diversas questões relacionadas aos direitos da pessoa com deficiência, sendo claramente compartilhado o dever da família, da sociedade e do Estado.

Art. 227. É dever da família, da sociedade e do Estado assegurar à criança, ao adolescente e ao jovem, com absoluta prioridade, o direito à vida, à saúde, à alimentação, à educação, ao lazer, à profissionalização, à cultura, à dignidade, ao respeito, à liberdade e à convivência familiar e comunitária, além de colocá-los a salvo de toda forma de negligência, discriminação, exploração, violência, crueldade e opressão.

$\S 1^{\circ} \mathrm{O}$ Estado promoverá programas de assistência integral à saúde da criança, do adolescente e do jovem, admitida a participação de entidades não governamentais, mediante políticas específicas e obedecendo aos seguintes preceitos:

[...]

II - criação de programas de prevenção e atendimento especializado para as pessoas portadoras de deficiência física, sensorial ou mental, bem como de integração social do adolescente e do jovem portador de deficiência, mediante o treinamento para o trabalho e a convivência, e a facilitação do acesso aos bens e serviços coletivos, com a eliminação de obstáculos arquitetônicos e de todas as formas de discriminação.

$\S 2^{\circ}$ - A lei disporá sobre normas de construção dos logradouros e dos edifícios de uso público e de fabricação de veículos de transporte coletivo, a fim de garantir acesso adequado às pessoas portadoras de deficiência. ${ }^{152}$

Resta cristalino que a inclusão da pessoa com deficiência inicia-se através da relação familiar e, ato contínuo, extrapola para o âmbito da comunidade. Assim sendo, somente neste segundo momento caberá ao Estado o cumprimento das normas dispostas na Constituição e na legislação infraconstitucional.

\footnotetext{
p. 180.

${ }^{151}$ BRASIL. Constituição de 1988. Op. cit.

${ }^{152}$ Ibidem.
} 
Torna-se extremamente importante a observância da geração de programas de prevenção e de atendimento especializado, ao passo que uma grande parcela das deficiências é decorrente de problemas durante a gestação ou complicações após o parto.

A eliminação das barreiras arquitetônicas é outro aspecto que merece destaque, tendo em vista que a Constituição Federal de 1988 também trata sobre a questão da acessibilidade da pessoa com deficiência. Afastar as dificuldades arquitetônicas viabiliza sobremaneira a inclusão da pessoa com deficiência, tendo em vista que proporciona o acesso às escolas, aos hospitais e, em especial, aos locais de trabalho.

Por fim, cumpre mencionar que a Constituição de 1988 aponta instrumentos de proteção e garantia dos direitos fundamentais das pessoas deficientes, como, por exemplo, o mandado de segurança coletivo (artigo $5^{\circ}$, inciso LXX) e a ação civil pública (artigo 129, inciso III).

Neste contexto, cumpre lembrar a finalidade do mandado de segurança coletivo, sendo facilitador do acesso à Justiça na medida em que evita a multiplicidade de ações com o mesmo objeto, sendo certo que se presta à defesa de todas as espécies de interesses transindividuais, incluídos os direitos ou interesses difusos, coletivos e individuais homogêneos.

Por outra esteira, a ação civil pública pode ter por objeto a condenação em dinheiro ou o cumprimento de obrigação de fazer ou de não fazer, e destina-se à proteção de todos os direitos transindividuais, ou seja, direitos e interesses coletivos, difusos e individuais homogêneos. No tocante à pessoa com deficiência, o artigo $3^{\circ}$ da Lei n. 7.853, de 24 de outubro de 1989, expressamente prevê o cabimento de ação civil pública para proteção de direitos coletivos ou difusos de tal grupo e aponta os legitimados (Ministério Público, União, Estados, Municípios e Distrito Federal, associação constituída há mais de um ano, nos termos da lei civil, autarquia, empresa pública, fundação ou sociedade de economia mista que inclua, entre suas finalidades institucionais, a proteção das pessoas com deficiência). 
Conclui-se que a Constituição de 1988 prevê significativa proteção à pessoa com deficiência, seja no setor público ou no privado, bem como é específica quanto à igualdade dos trabalhadores, sejam estes deficientes ou não.

\subsection{O princípio da igualdade e as ações afirmativas}

Perfilhando no caminho da análise das conquistas percebidas pelas pessoas com deficiências e refletidas na Constituição de 1988, imperioso ventilar algumas observações acerca do princípio da igualdade, consolidado pelo caput do artigo $5^{\circ}$ da Magna Carta. Para tanto, se faz necessário traçar algumas ponderações acerca da evolução e compreensão do princípio da igualdade, esclarecendo a linha divisória entre a igualdade formal e a igualdade material.

Inicialmente, a concepção de igualdade, decorrente da Revolução Francesa, detinha um caráter eminentemente formal. Nota-se que o modelo liberal clássico apontava que a igualdade deveria ser observada quando da aplicação das leis; portanto, o princípio da igualdade dirigia-se apenas ao aplicador da norma, que deveria aplicá-la a todos indistintamente, não sendo aceitável a concessão de privilégios ou distinções. ${ }^{153}$

A este respeito, Carlos Roberto Siqueira Castro pondera que:

a regra de que todos são iguais perante a lei, ou de que todos merecem a mesma proteção da lei, entre outros enunciados expressivos da isonomia puramente formal e jurídica, traduz, em sua origem mais genuína, a exigência de simples igualdade entre os sujeitos de direito perante a ordem normativa, impedindo que se crie tratamento diverso para idênticas ou assemelhadas situações de fato. Impede, em suma, que o legislador trate desigualmente os iguais. ${ }^{154}$

E ainda, seguindo a mesma linha de raciocínio, Celso de Albuquerque Mello destaca que:

${ }^{153}$ GOLDFARB, Cibelle Linero. Op. cit., p. 104.

${ }^{154}$ CASTRO, Carlos Roberto de Siqueira. O princípio da isonomia e a igualdade da mulher no Direito Constitucional. Rio de Janeiro: Forense, 1983, p. 35-36, apud SILVA, Fernanda Duarte Lopes Lucas da. Princípio constitucional da igualdade. Rio de Janeiro: Editora Lumen Juris, 2001, p. 37-38. 
O princípio da igualdade aliado ao da liberdade vão caracterizar, no plano do Direito, o que se denominou de individualismo jurídico. A liberdade de contratar, aliada à ideia de igualdade política, consagra $\mathrm{o}$ capitalismo do século XIV com a exploração das massas operárias. ${ }^{155}$

Resta o entendimento de que a igualdade formal não aborda a questão da adoção de medidas que pudessem diminuir as discrepâncias sociais e econômicas entre todos os cidadãos. Portanto, não confere a proteção especial que determinados indivíduos necessitam, em especial, as pessoas com deficiências, ao passo que limita acentuar a regra da plena nivelação de todos os indivíduos perante a lei.

Diante deste entendimento, a igualdade meramente formal passou a ser afastada ao final do século XIX, quando se constatava na Europa uma enorme desigualdade social, não existindo qualquer proteção legal aos trabalhadores, acarretando a execução de elevadas jornadas de trabalho, em ambientes sem respeito à dignidade humana, sendo certo que a força de trabalho naquele momento histórico era considerada uma mercadoria. ${ }^{156}$

Neste sentido, o desejo de uma igualdade material (real) encontra-se visível nas manifestações operárias do início do século XX e, sobre esse momento, esclarece Manoel Jorge da Silva Neto:

destarte, o fenômeno da positivação constitucional dos elementos sócioideológicos tem por causa eficiente a própria questão social, porquanto floresceu o capitalismo em regime de concentração dos meios de produção e também da insidiosa realidade do trabalho encarado como mercadoria, além da adversidade de condições em que era prestado. ${ }^{157}$

Assim sendo, a igualdade material ou igualdade na lei representa uma autorização para desigualar em busca da igualdade, diante da necessidade de conferir proteção especial aos direitos de certas pessoas ou grupos. ${ }^{158}$

\footnotetext{
${ }^{155}$ MELLO, Celso de Albuquerque. O princípio da igualdade no Direito Internacional Público. Revista da Ordem dos Advogados do Brasil. Rio de Janeiro, v. 20, n. 15, 1981, p. 12.

${ }^{156}$ GOLDFARB, Cibelle Linero. Op. cit., p. 105.

${ }^{157}$ SILVA NETO, Manoel Jorge e. Proteção constitucional dos interesses trabalhistas difusos, coletivos e individuais homogêneos. São Paulo, LTr, 2001, p. 52.

158 ARAÚJO, Luiz Alberto David. A proteção constitucional das pessoas portadoras de deficiência. 2. ed. Brasília: Corde, 1996, p. 82.
} 
Outrossim, busca-se estabelecer uma equivalência de direitos, sendo certo que a inserção de tais direitos na esfera constitucional trouxe consequências imediatas, ao passo que o Estado passou a ser demandado no sentido de prestar referidos direitos.

Portanto, sendo reconhecida a necessidade de uma igualdade real, e não meramente formal, a igualdade de oportunidades efetivamente terá espaço perante a sociedade. E diante deste panorama direciona-se a atenção dos legisladores às necessidades de determinados grupos sociais, como, por exemplo, as pessoas com deficiências, os idosos, as crianças, entre outros.

Como indagado, a Constituição Federal de 1988 é cristalina no tocante à competência do Estado brasileiro para a tomada de ações que favoreçam a efetivação dos fundamentos e dos objetivos traçados em seu texto. E, ainda, não se limita a prever a igualdade entre homens e mulheres, mas enfatiza o princípio da igualdade em inúmeros dispositivos legais e dispõe sobre as medidas para sua concretização.

Seguindo esta linha, uma das formas de concretizar o princípio da igualdade seria a proibição de toda e qualquer forma de discriminação, seja em razão da raça, cor, sexo, religião, deficiência, ou ainda em razão de qualquer forma de diferença.

Com o decorrer dos anos, observou-se que certas discriminações encontravam-se entrelaçadas à cultura e à sociedade, sendo extremamente complicado de serem afastadas. Diante deste panorama, constatou-se que a incorporação do princípio da igualdade no texto constitucional e, ainda, a expressa vedação das práticas discriminatórias não seriam suficientes para impedir as desigualdades existentes na sociedade.

Neste momento histórico houve a necessidade do uso de medidas e políticas estatais ou privadas, possíveis de reduzir o processo discriminatório e seus efeitos nocivos.

Diante deste cenário, iniciou-se na década de 1960, nas cortes superiores norteamericanas, o movimento conhecido por "ações afirmativas" ou "discriminação positiva", 
que atualmente encontra espaço em inúmeros países, dentre eles o Brasil. ${ }^{159}$

No tocante à origem da expressão "ação afirmativa", imperioso ponderar os argumentos da doutrinadora Carmen Lúcia Antunes Rocha:

A expressão ação afirmativa, utilizada pela primeira vez numa ordem executiva federal norte-americana do mesmo ano de 1965, passou a significar, desde então, a exigência de favorecimento de algumas minorias socialmente inferiorizadas, vale dizer, juridicamente desigualadas, por preconceitos arraigados culturalmente e que precisavam ser superados para que se atingisse a eficácia da igualdade preconizada e assegurada constitucionalmente na principiologia dos direitos fundamentais. ${ }^{160}$

Nota-se que as ações afirmativas podem ser consideradas como medidas possíveis de compensar a inferioridade econômica e social de certas minorias, através do intermédio de políticas de garantia de emprego, no âmbito público ou privado. ${ }^{161}$

Desta feita, conclui-se que as ações afirmativas englobam as políticas e os programas implementados pelo Poder Público ou por particulares com intuito de proporcionar oportunidades semelhantes aos grupos identificados como "minoritários", dentre eles, as pessoas com deficiência. Portanto, sem que exista o afastamento dos direitos das maiorias, o que de fato se pretende é valorizar e aumentar a participação dos grupos minoritários, garantindo a plenitude de seus direitos e a possibilidade de efetiva igualdade perante toda a sociedade.

Sendo certo que as ações afirmativas são mecanismos compensatórios, estas podem ser utilizadas para inserir determinados grupos sociais no exercício do direito ao trabalho. Nesta esteira, constituem ações afirmativas: o sistema de cotas, a concessão de benefícios e subsídios às empresas, deduções, entre outras.

Cumpre destacar que o Brasil adotou o sistema de cotas puro, para a reserva de

\footnotetext{
${ }^{159}$ GOLDFARB, Cibelle Linero. Op. cit., p. 113.

${ }^{160}$ ROCHA, Carmen Lúcia Antunes. Ação afirmativa: o conteúdo democrático do princípio da igualdade jurídica. Revista de Informação Legislativa. Brasília, ano 33, n. 131, jul./set. 1996, p. 285.

${ }^{161}$ COMPARATO, Fábio Konder. Igualdade, desigualdades. Revista Trimestral de Direito Público. São Paulo, v. 1, 1993, p. 77.
} 
mercado de trabalho às pessoas com deficiência nos concursos públicos e nas empresas privadas com mais de cem empregados, não sendo possível substituir a reserva de vagas por eventual contribuição monetária destinada a um fundo, ao passo que se exige a vinculação direta do empregador com a pessoa com deficiência. ${ }^{162}$

De fato, o sistema de cotas para a inclusão da pessoa deficiente ao mercado de trabalho configura relevante ação afirmativa, razão pela qual será tratado em tópico específico pelo presente trabalho.

\subsection{Sistema legal de reserva de vagas ou sistema de cotas no Brasil: setor privado}

Em linhas gerais, o Brasil escolheu a adoção de um sistema de cotas ou reserva legal para estimular e garantir a inclusão da pessoa com deficiência ao mercado de trabalho.

Assim sendo, incluir uma pessoa deficiente ao mercado de trabalho é tarefa árdua e envolve inúmeros aspectos, como o cuidado com a educação, a qualificação, a eliminação de barreiras arquitetônicas, a adequação do ambiente de trabalho, elementos estes que não são contemplados pelo sistema de cotas isoladamente. ${ }^{163}$

A reserva de mercado de trabalho da pessoa com deficiência, no âmbito da empresa privada, encontra-se regulada no artigo 93 da Lei n. 8.213, de 24 de julho de 1991, que dispõe sobre os planos de Benefícios da Previdência Social, in verbis:

Art. 93. A empresa com 100 (cem) ou mais empregados está obrigada a preencher de $2 \%$ (dois por cento) a $5 \%$ (cinco por cento) dos seus cargos com beneficiários reabilitados ou pessoas portadoras de deficiência, habilitadas, na seguinte proporção:

I - até 200 empregados.................................................................

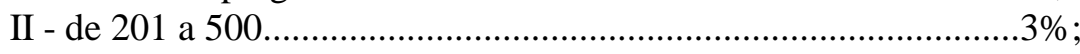

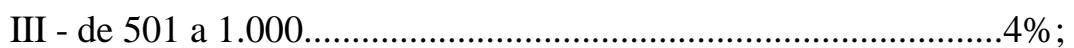

IV - de 1.001 em diante..................................................................5\%.

$\S 1^{\circ}$ A dispensa de trabalhador reabilitado ou de deficiente habilitado ao final de contrato por prazo determinado de mais de 90 (noventa) dias, e a

${ }^{162}$ COSTA, Sandra Morais de Brito. Op. cit., p. 121.

${ }^{163}$ GOMES, Joaquim B. Barbosa. Ação afirmativa e princípio constitucional da igualdade: o direito como instrumento de transformação social: a experiência dos EUA. Rio de Janeiro: Renovar, 2001, p. 40. 
imotivada, no contrato por prazo indeterminado, só poderá ocorrer após a contratação de substituto de condição semelhante.

$\S 2^{\circ} \mathrm{O}$ Ministério do Trabalho e da Previdência Social deverá gerar estatísticas sobre o total de empregados e as vagas preenchidas por reabilitados e deficientes habilitados, fornecendo-as, quando solicitadas, aos sindicatos ou entidades representativas dos empregados. ${ }^{164}$

Nota-se que o Decreto n. 3.298, de 20 de dezembro de 1999, regulamentou a Lei n. 7.853, de 24 de outubro de 1989, bem como introduziu algumas disposições adicionais relativas ao conceito da pessoa com deficiência.

Cumpre destacar, que no presente tópico, será abordada, tão somente, a reserva de mercado de trabalho da pessoa com deficiência, no âmbito da empresa privada, tendo em vista que as peculiaridades no setor público já foram traçadas em tópico anterior.

No tocante aos beneficiários da política implementada, nota-se que a lei incluiu no âmbito de proteção todas as pessoas com deficiência habilitadas e os trabalhadores reabilitados. E, ainda, a delimitação do público que se pretende incluir no mercado de trabalho em razão da implementação da reserva legal encontra-se prevista no Decreto $\mathrm{n}$. 3.298, de 20 de dezembro de 1999, o qual em seu artigo $4^{\circ}$ apresenta um rol restritivo de hipóteses.

Assim, são consideradas pessoas com deficiência física aquelas que possuem alteração completa ou parcial de um ou mais segmentos do corpo humano, acarretando o comprometimento da função física, apresentando-se sob a forma de paraplegia, paraparesia, monoplegia, monoparesia, tetraplegia, tetraparesia, triplegia, triparesia, hemiplegia, hemiparesia, ostomia, amputação ou ausência de membro, paralisia cerebral, nanismo, membros com deformidade congênita ou adquirida, exceto as deformidades estéticas e as que não produzam dificuldades para o desempenho de funções.

A deficiência auditiva refere-se à perda bilateral, parcial ou total, de quarenta e um decibéis $(\mathrm{dB})$ ou mais, aferida por audiograma nas frequências de 500 $\mathrm{HZ}, 1.000 \mathrm{HZ}$, $2.000 \mathrm{~Hz}$ e $3.000 \mathrm{~Hz}$. A deficiência visual corresponde à cegueira, na qual a acuidade visual

164 BRASIL. Lei n. 8.213, de 24 de julho de 1991 . Disponível em: <http://www.planalto.gov.br/ccivil_03/leis/L8213compilado.htm〉. Acesso em: 13 dez. 2012. 
é igual ou menor que 0,05 no melhor olho, com a melhor correção óptica; à baixa visão, que significa acuidade visual entre 0,3 e 0,05 no melhor olho, com a melhor correção óptica; aos casos nos quais a somatória da medida do campo visual em ambos os olhos for igual ou menor que $60^{\circ}$; ou à ocorrência simultânea de quaisquer das condições anteriores.

No tocante à visão monocular, apesar da ausência de previsão no Decreto n. 3.298/99, mas em razão da publicação da Lei n. 14.481, do Estado de São Paulo, de 13 de julho de 2011, resta considerada como deficiência visual a visão monocular.

Nesse passo, a deficiência mental é definida como o funcionamento intelectual significativamente inferior à média, com manifestação antes dos dezoito anos e limitações associadas a duas ou mais áreas de habilidades adaptativas, tais como: a) comunicação; b) cuidado pessoal; c) habilidades sociais; d) utilização dos recursos da comunidade; e) saúde e segurança; f) habilidades acadêmicas; g) lazer; e h) trabalho. Cumpre esclarecer que a deficiência múltipla será considerada de acordo com a associação de duas ou mais deficiências.

De acordo com o Decreto n. 3.298/99, considera-se pessoa com deficiência habilitada aquela que concluiu curso de educação profissional de nível básico, técnico ou tecnológico, ou curso superior, com certificação ou diplomação expedida por instituição pública ou privada, legalmente credenciada pelo Ministério da Educação ou órgão equivalente, ou aquela com certificado de conclusão de processo de habilitação ou reabilitação profissional fornecido pelo Instituto Nacional do Seguro Social - INSS, e ainda, aquela que, não tendo se submetido a processo de habilitação ou reabilitação, esteja capacitada para o exercício da função.

Para melhor entendimento sobre o tema, importante ponderar, de acordo com o texto da Lei n. 8.213/91, em seu artigo 89, que:

a habilitação e a reabilitação profissional e social deverão proporcionar ao beneficiário incapacitado parcial ou totalmente para o trabalho, e às pessoas portadoras de deficiência, os meios para a (re)educação e de 
(re)adaptação profissional e social indicados para participar do mercado de trabalho e do contexto em que vive. ${ }^{165}$

E, ainda, indica que a reabilitação profissional compreende:

a) o fornecimento de aparelho de prótese, órtese e instrumentos de auxílio para locomoção quando a perda ou redução da capacidade funcional puder ser atenuada por seu uso e dos equipamentos necessários à habilitação e reabilitação social e profissional; b) a reparação ou a substituição dos aparelhos mencionados no inciso anterior, desgastados pelo uso normal ou por ocorrência estranha à vontade do beneficiário; e c) o transporte do acidentado do trabalho, quando necessário. ${ }^{166}$

Resta clara a existência de uma barreira quanto ao direito à habilitação e à reabilitação profissional da pessoa deficiente, conforme previsto no artigo 90 da Lei $n$. 8.213/91. A determinação caminha no sentido de que a prestação será devida em caráter obrigatório aos segurados, inclusive aposentados, e, na medida das possibilidades do órgão da Previdência Social, aos seus dependentes, limitando o acesso da pessoa deficiente que não possui a qualidade de segurado.

Clareando o entendimento do referido dispositivo, Walküre Lopes Ribeiro da Silva, de maneira cristalina indaga que:

a Constituição, no art. 203, IV, garante a prestação dos referidos serviços, mesmo ausente a qualidade de segurado. A prestação é assistencial por sua natureza e finalidade. Aliás, o caput do art. 203 dispõe expressamente que as medidas nele previstas dirigem-se a todos que tenham necessidade, independentemente de contribuição. ${ }^{167}$

Cumpre destacar que o primeiro capítulo do presente trabalho abordou de maneira pormenorizada o conceito da pessoa com deficiência, razão pela qual neste tópico foram apontados, tão somente, breves esclarecimentos sobre o referido conceito.

Da análise da legislação brasileira, denota-se que houve a vinculação de cotas em razão do número de empregados da empresa; entretanto, restaram isentas de obrigações as

\footnotetext{
${ }^{165}$ BRASIL. Lei n. 8.213/1991. Op. cit.

${ }^{166}$ Ibidem.

${ }^{167}$ SILVA, Walküre Lopes Ribeiro da. Op. cit., p. 181.
} 
empresas com menos de cem empregados. Nesta linha, observa-se que o legislador não se preocupou em analisar outros aspectos quantitativos ou qualitativos, como, por exemplo, a receita bruta da empresa, a atividade exercida pelo empregador ou, ainda, o número de empregados indiretos.

No Brasil, qualquer pessoa com deficiência pode ser contratada, desde que demonstre a capacidade para assumir as atividades atinentes à vaga de trabalho ofertada.

Mas, de fato, contratar uma pessoa com deficiência implica, na maioria das vezes, a realização de modificações arquitetônicas da empresa, aquisição de equipamentos específicos e treinamento de pessoal, tornando este projeto, muitas vezes, extremamente dispendioso para empregador. Ainda, muitos empregadores argumentam quanto à falta de pessoas deficientes aptas para o desempenho de determinadas funções, ou que o quadro de empregados da empresa estaria preenchido, razão pela qual não teriam como suportar o acréscimo de contratação.

Segundo o entendimento do doutrinador Carlos Henrique Bezerra Leite, empregado é uma espécie de trabalhador subordinado que, com tal ânimo, de forma não eventual e mediante remuneração, coloca, pessoalmente, a sua força de trabalho à disposição de um empregador, em decorrência de um contrato de trabalho. ${ }^{168}$ Por esta razão, não se pode esquecer que o sistema de preenchimento de reserva legal brasileiro apresenta uma peculiaridade, porquanto a contratação da pessoa com deficiência deve seguir obrigatoriamente através da elaboração de contrato de trabalho padrão.

Diante deste panorama, é possível observar que o sistema de cotas, quando utilizado de maneira isolada, revela-se ineficiente para promover a inserção da pessoa com deficiência ao mercado de trabalho. As empresas, quando forçadas a admitir, tendem a cumprir a obrigação, alocando o deficiente em atividades ou setores marginais, agravando ainda mais a situação de exclusão desta categoria de pessoas. ${ }^{169}$

${ }^{168}$ LEITE, Carlos Henrique Bezerra. Constituição de direitos sociais dos trabalhadores. São Paulo: LTr, 1997, p. 31.

${ }^{169}$ COSTA, Sandra Morais de Brito. Op. cit., p. 109. 
Como de fato ocorre, a inserção da pessoa com deficiência ao mercado de trabalho depende, em especial, da qualificação do candidato e do interesse do empregador. Assim sendo, é possível atentar que o sistema legal de reserva de vagas, quando acompanhado de outras medidas complementares que estimulem a contratação de pessoas deficientes, tornase mais eficiente, bem como que os empregadores tornam-se mais receptivos à contratação, tendo em vista que acumulam boas experiências. Dentro deste panorama, observa-se que o sistema de cotas deve estar aliado a leis, programas de incentivos e instituições que possam facilitar a inclusão da pessoa com deficiência no mercado de trabalho.

Na Europa é comum a concessão de outros benefícios aos empregadores, como bônus, deduções ou subsídios, para que cumpram ou superem as cotas legais. A França, amplamente conhecida por sua legislação flexível, admite que as empresas incluam, na contagem de suas cotas, as pessoas com deficiência que trabalhem de forma terceirizada em entidades de trabalho protegido. ${ }^{170}$

A Lei argentina n. 24.465, de 15 de março de 1995, prevê meios de fomento ao emprego e cria um contrato de trabalho especial, com duração de seis meses, prorrogável por mais seis meses e duração máxima de dois anos, destinado a pessoas maiores de quarenta anos de idade, pessoas com deficiências, mulheres e ex-combatentes da Guerra das Malvinas. Nessa modalidade de contrato, os empregadores encontram um abatimento de $50 \%$ do valor das contribuições patronais destinadas ao sistema de seguridade social. ${ }^{171}$

Alguns países adotam de forma cumulativa o sistema de cota-contribuição como alternativa para os empregadores que não conseguem cumprir o preenchimento da reserva legal de vagas, total ou parcialmente. O empregador paga um valor por pessoa com deficiência que deixar de contratar para um fundo destinado especialmente a recolher a contribuição e estimular o preenchimento de cotas e o ingresso de pessoas deficientes ao mercado de trabalho. ${ }^{172}$

Por outra esteira, necessário enfatizar que o ônus puramente patrimonial para o

\footnotetext{
${ }^{170}$ COSTA, Sandra Morais de Brito. Op. cit., p. 106.

${ }^{171}$ GOLDFARB, Cibelle Linero. Op. cit., p. 148.

${ }^{172}$ LOPES, Glaucia Gomes Vergara. Op. cit., p. 94.
} 
empregador que deixa de cumprir a cota estipulada por lei não seria suficiente para inibir a ausência de contratação. Estratégias como estabelecer como requisito para a participação em licitações públicas a comprovação do preenchimento das cotas previstas no artigo 93 da Lei n. 8.213/91, ou ainda o prejuízo na obtenção de certidões negativas, poderiam acarretar uma maior preocupação e afastariam as situações em que o empregador opta por pagar a multa aplicada ao invés de contratar uma pessoa deficiente.

\subsubsection{Questões polêmicas acerca do Sistema Legal de Reserva de Vagas}

Algumas questões relativas ao cumprimento do sistema de reserva legal para a inclusão de pessoas deficientes no mercado de trabalho devem ser pontuadas, quais sejam: a) como proceder com o preenchimento das vagas para as empresas com atividades sazonais; b) empresas que atuam com as atividades de vigilância; c) trabalho em minas e subsolos ou, ainda, atividades altamente insalubres ou perigosas; d) contratação de um único tipo de deficiência; e) como abordar o aspecto da inclusão das "deficiências" não contempladas pela Lei n. 8.213/91 e pelo Decreto n. 3.298/99, uma análise comparativa da Súmula n. 377 do Superior Tribunal de Justiça e da Lei n. 14.481, do Estado de São Paulo, de 13 de julho de 2011.

Primeiramente, é necessário ponderar que, não obstante os possíveis óbices indicados, o que na prática pode ser observado é que toda e qualquer empresa com cem ou mais empregados, deve cumprir o disposto no artigo 93 da Lei n. 8.213/91, incluindo, sem limitação, as empresas com atividades sazonais.

Portanto, para a aferição do número de empregados deficientes que deverão ser contratados, tendo em vista que as empresas com atividades sazonais seriam obrigadas a contratar empregados com deficiência apenas em determinados períodos, e em razão da omissão da norma sobre o tema, utiliza-se por analogia a Norma Regulamentadora n. 4 SESMT - item 4.6, ${ }^{173}$ que indica a média de empregados vinculados à empresa nos últimos doze meses. ${ }^{174}$

\footnotetext{
${ }^{173}$ COSTA, Sandra Morais de Brito. Op. cit., p. 144.

174 Item 4.6: "Os Serviços Especializados em Engenharia de Segurança e em Medicina do Trabalho das empresas que operem em regime sazonal deverão ser dimensionados, tomando-se por base a média aritmética
} 
Acrescenta-se que, no caso das empresas suprarreferidas, para que não exista um engessamento da atividade, a cota deve ser auferida e adequada anualmente.

No tocante às empresas que atuam em ramos especializados, como, por exemplo, o caso das empresas de vigilância patrimonial e transportes de valores, vale mencionar que não existe exceção quanto à base de cálculo relativa ao sistema de cotas compulsórias.

Para o exercício da atividade de vigilante, de acordo com a Lei n. 7.102, de 20 de junho de 1983, e com o Decreto n. 89.056, de 24 de novembro de 1983, faz-se necessário o preenchimento dos seguintes requisitos:

Art. 16 - Para o exercício da profissão, o vigilante preencherá os seguintes requisitos:

I - ser brasileiro;

II - ter idade mínima de 21 (vinte e um) anos;

III - ter instrução correspondente à quarta série do primeiro grau;

IV - ter sido aprovado, em curso de formação de vigilante, realizado em estabelecimento com funcionamento autorizado nos termos desta lei.

V - ter sido aprovado em exame de saúde física, mental e psicotécnico;

VI - não ter antecedentes criminais registrados; e

VII - estar quite com as obrigações eleitorais e militares. ${ }^{175}$

Assim sendo, observados os requisitos ora apontados, nota-se que, de acordo com o disposto na legislação brasileira, não é possível alegar que as empresas de vigilância não estejam obrigadas a cumprir com o sistema de cotas compulsórias.

Além disso, aponta-se que tais empresas não possuem apenas vigilantes em seu quadro de empregados, sendo certo que existem vagas e demandas de labor (por exemplo, no setor administrativo ou na área de monitoramento eletrônico) que pode ser realizado por empregados que não detenham as qualificações ou as aptidões para o cargo de vigilante.

do número de trabalhadores do ano civil anterior e obedecidos os Quadros I e II anexos." (BRASIL. Ministério do Trabalho e Emprego. NR n. 4: serviços especializados em engenharia de segurança e em medicina do trabalho. Disponível em: <http://portal.mte.gov.br/data/files/ 8a7c812d36a2800001388128376306ad/nr-04\%20(atualizada).pdf>. Acesso em: 17 dez. 2012).

175 BRASIL. Lei n. 7.102, de 20 de junho de 1983. Disponível em: <http://www.planalto.gov.br/ccivil_03/leis/L7102compilado.htm〉. Acesso em: 17 dez. 2012. 
Nesse contexto, a contratação de pessoas com deficiência não depende da função a ser desempenhada, mas do número de empregados na empresa.

Cumpre ao empregador, no exercício do seu poder diretivo, determinar quais cargos podem ou devem ser preenchidos pelos empregados com deficiência, observadas as peculiaridades e limitações próprias de cada função. ${ }^{176}$

Desta feita, por mais especializado que seja o ramo da atividade de uma empresa, dificilmente todas as funções existentes demandarão capacidades tão específicas que impossibilitem totalmente o acesso e a inclusão da pessoa com deficiência no ambiente de trabalho. $^{177}$

Não havendo a possibilidade de assumir qualquer exceção, se a empresa deixar de cumprir o preenchimento das cotas estabelecidas no artigo 93 da Lei n. 8.213/91, poderá ser autuada quando de eventual fiscalização.

Quanto às empresas que desempenham atividades predominantemente insalubres ou perigosas, em princípio não existe qualquer impedimento para a contratação de empregados com deficiências, não podendo ser assumida qualquer incompatibilidade entre a deficiência e o trabalho em local insalubre ou perigoso.

De qualquer maneira, todo e qualquer labor exercido pela pessoa com deficiência não pode agravar, direta ou indiretamente, sua deficiência ou ocasionar prejuízo à saúde do trabalhador.

Neste caminho, sendo as normas de medicina e segurança do trabalho consideradas dispositivos de ordem pública, a incompatibilidade devidamente atestada (laudo de perícia técnica) de que as atividades da empresa não podem ser exercidas por pessoas com deficiência ou podem acarretar prejuízos à saúde destas poderia desonerar o empregador do cumprimento da cota. Contudo, a simples alegação, por parte da empresa, de que os cargos

\footnotetext{
${ }^{176}$ COSTA, Sandra Morais de Brito. Op. cit., p. 146.

${ }^{177}$ GOLDFARB, Cibelle Linero. Op. cit., p. 141.
} 
disponíveis não podem ser ocupados por pessoas deficientes, por si só, mostra-se ineficiente e discriminatória. ${ }^{178}$

O que deve ficar claro é que não basta uma convicção subjetiva acerca da incompatibilidade ou da existência de razões de segurança, deve existir a demonstração de fato do prejuízo ou da incompatibilidade alegada.

Outra controvérsia que merece destaque é a contratação de um único tipo de deficiência. Referida atitude pode ser entendida como uma prática discriminatória, tendo em vista que a finalidade da legislação é garantir o acesso ao trabalho a todas as modalidades de deficiências.

A contratação apenas de empregados com deficiências leves também pode ser considerada uma atitude discriminatória. O que deve ser almejado é a inclusão da pessoa e não de sua deficiência, sendo certo que a pessoa deficiente tem direito ao respeito, sejam quais forem as severidades de suas deficiências.

A atitude de associar funções a determinadas deficiências também merece ser afastada. De forma exemplificativa, é possível mencionar o trabalho do deficiente auditivo em almoxarifados e do deficiente visual em telefonia, ou, ainda, de pessoas com deficiências visuais trabalhando em câmaras escuras e de deficientes auditivos trabalhando em lugares com excessivo ruído. Referida correlação mostra-se absolutamente restritiva, ao passo que não permite o desenvolvimento das potencialidades destas pessoas no ambiente de trabalho, bem como afasta suas possibilidades de inclusão no mercado de trabalho.

Portanto, antes de ceifar suas possibilidades de desenvolvimento ou afirmar que uma pessoa com deficiência não possui habilidades para trabalhar em determinada função, é preciso fornecer a oportunidade para que possa desempenhar suas reais habilidades, devendo ser observada inclusive a adaptação dos postos de trabalho.

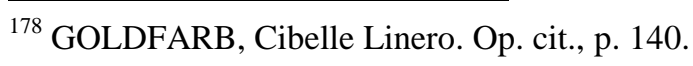


Por fim, outro aspecto que merece importante destaque refere-se à inclusão de pessoas ou "padrões" não contemplados na Lei n. 8.213/91 e no Decreto n. 3.298/99 para fins do preenchimento da reserva legal.

Perfilhando nesta seara, as pessoas queimadas, com surdez unilateral, lábio leporino e/ou fenda palatina, diabéticas insulino-dependentes, ex-cancerosas e obesas, formam um grupo de pessoas com características específicas, sendo certo que o disposto na Lei $\mathrm{n}$. 3.298/99 não prevê a inclusão desse tipo de "deficiência invisível”.

A exclusão no mercado de trabalho desta parcela da população é notória, bem como as inúmeras dificuldades encontradas quando da realização de um processo seletivo.

Portanto, analisando a legislação brasileira através de uma visão crítica, é possível ponderar a ausência de uma definição clara capaz de alcançar de fato um conceito amplo de deficiência insculpido pelo legislador, qual seja, toda perda ou anormalidade de uma estrutura ou função psicológica, fisiológica ou anatômica que gere incapacidade para o desempenho de atividade, dentro do padrão considerado normal para o ser humano. É possível afirmar, ainda, que o campo ora indagado é árido e suscita inúmeras discussões conflitantes e igualmente bem fundamentadas.

Com efeito, o artigo $4^{\circ}$, inciso I, do Decreto n. 3.298/99 exclui das deficiências físicas as deformidades estéticas e as que não produzam dificuldades para o desempenho de funções. Apesar do disposto na legislação vigente, difícil concordar com o entendimento de que toda a deficiência deva efetivamente reduzir a capacidade laborativa. Uma pessoa obesa ou que por um infortúnio da vida tenha a face queimada ou deformada, ainda que não venha a sofrer limitações físicas, auditivas, visuais ou mentais, e que não vislumbre qualquer redução da sua capacidade laborativa, certamente sofrerá preconceito quando de sua contratação.

Acredita-se que o Direito do Trabalho é um instrumento primordial para equilibrar a relação social e, portanto, não se deve perder de vista o valor social do trabalho, posto que constitui postulado básico da dignidade humana. Dentro desta realidade, nota-se que a 
dificuldade de inclusão no mercado de trabalho afasta sobremaneira o sentimento de dignidade do ser humano.

O mesmo entendimento pode ser traçado ao analisar a inclusão laboral da pessoa que nasce com lábio leporino e/ou fenda palatina. O indivíduo encontra barreiras sociais, mas não existe previsão normativa para a inclusão desta deficiência invisível.

Para melhor entendimento do tema, cumpre destacar que a fissura labial e a fenda palatina, são malformações congênitas, de apresentação variável, que ocorrem durante o desenvolvimento do embrião. A fissura labial, ou lábio leporino, é uma abertura que começa na lateral do lábio superior, dividindo-o em dois segmentos. Essa falha no fechamento das estruturas pode restringir-se ao lábio ou estender-se até o sulco entre os dentes incisivo lateral e canino, atingir a gengiva, o maxilar superior e alcançar o nariz. Por outro lado, a fenda palatina é uma abertura que pode atingir todo o céu da boca e a base do nariz, estabelecendo comunicação direta entre um e outro. ${ }^{179}$

É importante destacar que as fissuras labiopalatinas não são alterações de caráter puramente estético e podem causar inúmeros problemas de saúde, que incluem distúrbios respiratórios, de fala e de audição, infecções crônicas e alterações na dentição.

Quanto à surdez unilateral, de fato esta não impede o exercício de uma profissão ou inclusão no mercado de trabalho, mas certamente deixa em desvantagem o candidato em relação a outra pessoa que tenha boa audição nos dois ouvidos.

De fato, a legislativa brasileira persegue um caminho evolutivo, sendo certo que o entendimento da Súmula n. 377 do Superior Tribunal de Justiça ${ }^{180}$ e da Lei n. 14.481/2011, do Estado de São Paulo, ${ }^{181}$ no tocante à pessoa com visão monocular, deve ser aplicado por analogia à pessoa com surdez unilateral.

179 VARELlA, Drauzio. Lábio leporino, fenda palatina. Disponível em: <http://drauziovarella.com.br/doencas-e-sintomas/labio-leporinofenda-palatina>. Acesso em: 17 dez. 2012.

${ }^{180}$ Súmula n. 377 do STJ: "O portador de visão monocular tem direito de concorrer, em concurso público, às vagas reservadas aos deficientes".

181 "Artigo $1^{\circ}$ - Fica classificada como deficiência visual a visão monocular." (SÃO PAULO (Estado). Lei n. 14.481, de 13 de julho de 2011. Disponível em: <http://www.al.sp.gov.br/repositorio/legislacao/lei/ 
Quanto à contratação de pessoas diabéticas insulino-dependentes e ex-cancerosas, ainda que de forma mais branda, é possível suscitar controvérsias quanto à perversa discriminação deste grupo de pessoas quando da realização de um processo seletivo. O que na prática a maior parte dos empregadores procura é contratar um empregado de "boa aparência", de "fácil comunicação", com "qualificações específicas para o cargo destinado", e claro, "saudável". A dependência de determinados medicamentos remete ao empregador uma ideia de que aquele empregado pode permanecer afastado por longos períodos, ou ainda demandar cuidados especiais.

Posto isso, e diante das inúmeras reflexões traçadas, se faz necessária uma abordagem ampla da expressão "inclusão" através da atividade profissional, elevando o respeito aos direitos e garantias do indivíduo e afastando qualquer imposição de condição, possibilidade ou padrão.

\subsubsection{A atuação do Ministério Público do Trabalho e do Ministério do Trabalho e Emprego e os mecanismos de incentivo para cumprimento da legislação}

A atuação do Ministério Público do Trabalho (MPT) quanto à inclusão da pessoa com deficiência no mercado de trabalho é marca decisiva nos aspectos orientadores e conciliatórios.

Segundo o entendimento do doutrinador Carlos Henrique Bezerra Leite, o MPT vem implementando o efetivo cumprimento do artigo 93 da Lei n. 8.213/91, que impõe seja observado percentual mínimo de $2 \%$ a $5 \%$ de trabalhadores com deficiência (física, visual, auditiva) para empresas com cem ou mais empregados. Também preocupa o MPT, sobretudo, a falta de política regulamentar nas empresas, mas também as práticas discriminatórias levadas a efeito quando da readaptação do empregado que retorna ao trabalho com deficiência por motivo de saúde ou acidente. ${ }^{182}$

2011/lei\%20n.14.481,\%20de\%2013.07.2011.htm>. Acesso em: 17 dez. 2012). Acesso em: 17 dez. 2012.

${ }^{182}$ LEITE, Carlos Henrique Bezerra. Ministério Público do Trabalho. São Paulo: LTr, 2006, p. 171. 
Nota-se que, atualmente, o Ministério Público do Trabalho (MPT) e o Ministério do Trabalho e Emprego (MTE) adotam procedimentos paralelos e semelhantes, sendo certo que no presente tópico serão abordadas de forma breve as condutas adotadas por cada um desses órgãos.

Inicialmente, menciona-se que o artigo 93, $\S 2^{\circ}$, da Lei n. 8.213/91 determina que o Ministério do Trabalho e da Previdência Social deverá gerar estatísticas sobre o total de empregados e as vagas preenchidas por reabilitados e deficientes habilitados, fornecendoas, quando solicitadas, aos sindicatos ou entidades representativas dos empregados. ${ }^{183}$

E, ainda, de acordo com o disposto no artigo 36, § 5 , do Decreto n. 3.298/99, compete ao MTE estabelecer a sistemática de fiscalização, avaliação e controle das empresas, bem como instituir procedimentos e formulários que propiciem estatísticas sobre o número de empregados portadores de deficiência e de vagas preenchidas, para fins de acompanhamento do cumprimento da reserva legal. ${ }^{184}$

O descumprimento da norma pode resultar em um auto de infração e multa administrativa. Também é possível encaminhar relatório ao MPT para as medidas legais cabíveis, o que se depreende do artigo $10, \S 5^{\circ}$, c/c o artigo 15 da Instrução Normativa 20/01. ${ }^{185}$

Merece ser destacado que a inspeção do trabalho, tendo em vista sua característica preventiva, tem como atribuição justamente acautelar discriminações, em especial quando observado o descumprimento injustificado de grandes empresas quanto ao preenchimento da reserva legal de pessoas deficientes.

Originalmente, de acordo com o disposto no artigo 133 da Lei n. 8.213/91, previase uma multa variável de Cr\$100.000,00 (cem mil cruzeiros) a Cr\$10.000.000,00 (dez

\footnotetext{
${ }^{183}$ BRASIL. Lei n. 8.213/1991. Op. cit.

${ }^{184}$ BRASIL. Decreto n. 3.298/1999. Op. cit.

${ }^{185}$ BRASIL. Ministério do Trabalho e Emprego. Instrução Normativa n. 20, de 26 de janeiro de 2001. Disponível em: <http://portal.mte.gov.br/legislacao/instrucao-normativa-n-20-de-26-01-2001.htm>. Acesso em: 18 dez. 2012.
} 
milhões de cruzeiros), podendo a autoridade reduzir ou relevar a multa aplicada, hipótese em que caberia recurso para a autoridade hierarquicamente superior.

Entretanto, em 28 de outubro de 2003, a Portaria n. 1.199 fixou parâmetros para a gradação da multa administrativa variável prevista no art. 133 da Lei n. 8.213/91, pela infração ao art. 93 da mesma Lei. Neste sentido, a multa passou a ser calculada na seguinte proporção:

I - para empresas com cem a duzentos empregados, multiplicar-se-á o número de trabalhadores portadores de deficiência ou beneficiários reabilitados que deixaram de ser contratados pelo valor mínimo legal, acrescido de zero a vinte por cento;

II - para empresas com duzentos e um a quinhentos empregados, multiplicar-se-á o número de trabalhadores portadores de deficiência ou beneficiários reabilitados que deixaram de ser contratados pelo valor mínimo legal, acrescido de vinte a trinta por cento;

III - para empresas com quinhentos e um a mil empregados, multiplicarse-á o número de trabalhadores portadores de deficiência ou beneficiários reabilitados que deixaram de ser contratados pelo valor mínimo legal, acrescido de trinta a quarenta por cento;

IV - para empresas com mais de mil empregados, multiplicar-se-á o número de trabalhadores portadores de deficiência ou beneficiários reabilitados que deixaram de ser contratados pelo valor mínimo legal, acrescido de quarenta a cinquenta por cento;

$\S 1^{\circ} \mathrm{O}$ valor mínimo legal a que se referem os incisos I a IV deste artigo é o previsto no artigo 133, da Lei $n^{\circ} 8.213$, de 1.991 .

$\S 2^{\circ} \mathrm{O}$ valor resultante da aplicação dos parâmetros previstos neste artigo não poderá ultrapassar o máximo estabelecido no artigo 133 da Lei $\mathrm{n}^{\circ}$ 8.213 , de $19911^{186}$

Os valores mínimo e máximo da multa são corrigidos anualmente pela portaria que reajusta os benefícios mantidos pela Previdência Social, sendo que atualmente o valor da multa pela infração a qualquer dispositivo do regulamento da Previdência Social, para a qual exista penalidade expressamente cominada, varia de $\mathrm{R} \$ 1.617,12$ (mil seiscentos e dezessete reais e doze centavos) a $\mathrm{R} \$ 161.710,08$ (cento e sessenta e um mil setecentos e dez reais e oito centavos), de acordo com o disposto na Portaria MPS/MF n. 02, de 06 de janeiro de $2012 .^{187}$

\footnotetext{
${ }^{186}$ BRASIL. Ministério do Trabalho e Emprego. Portaria n. 1.199, de 28 de outubro de 2003. Disponível em: <http://portal.mte.gov.br/legislacao/portaria-n-1-199-de-28-10-2003.htm>. Acesso em: 18 dez. 2012.

${ }^{187}$ BRASIL. Ministério da Previdência Social; Ministério da Fazenda. Portaria Interministerial MPS/MF n. 02, de 06 de janeiro de 2012. Disponível em: <http://www010.dataprev.gov.br/sislex/paginas $/ 65 / \mathrm{mf}$ mps/2012/2.htm>. Acesso em: 18 dez. 2012.
} 
Cumpre mencionar que a multa aplicável quando da dispensa de empregado deficiente, sem a contratação antecedente de substituto em condições semelhantes, será idêntica à da ausência de preenchimento da reserva legal.

Dentro deste contexto e valorizando o princípio da dignidade humana e da função social da empresa, de acordo com o disposto no artigo 93 da Lei n. 8.213/91, para a fiscalização deverá ser adotado o critério da totalidade de empregados, incluindo matriz e filiais. E, ainda, sobre a distribuição igualitária e democrática de pessoas com deficiências entre os estabelecimentos da empresa, cumpre mencionar a ausência de lei específica neste particular.

Importante ponderar que os Núcleos de Promoção de Igualdade de Oportunidades e de Combate à Discriminação, instalados nas delegacias regionais do trabalho por meio de programas institucionais, além de acolher denúncias de discriminação e promover Mesas de Entendimento entre as partes, desenvolvem ações educativas em parceria com diversas instituições, públicas e privadas. Todas as estratégias indicadas buscam viabilizar o combate às práticas discriminatórias no trabalho e a promoção da igualdade de oportunidades de todos na obtenção de um trabalho decente. ${ }^{188}$

No tocante ao MPT, as empresas obrigadas à reserva legal de vagas são convocadas a prestar esclarecimentos quanto ao cumprimento da norma, sendo certo que a identificação pode ser realizada através de diversos entes, dentre eles o MTE.

Na fase inicial, as empresas são instadas a informar o número de empregados e a apresentar documentação comprobatória do cumprimento da cota legal. ${ }^{189}$ Ato contínuo, e sendo observado que a empresa não cumpre a reserva legal, o Procurador do Trabalho pode instaurar um procedimento investigatório, buscando o cumprimento da exigência legal. ${ }^{190}$

\footnotetext{
${ }^{188}$ COSTA, Sandra Morais de Brito. Op. cit., p. 191.

189 Art. $8^{\circ}$, inciso IV, da Lei Complementar n. 75/93. (BRASIL. Lei Complementar n. 75, 20 de maio de 1993. Disponível em: <http://www.planalto.gov.br/ccivil_03/leis/lcp/lcp75.htm〉. Acesso em: $18 \mathrm{dez} .2012$ ).

${ }^{190}$ KALUME, Pedro de Alcântara. Deficientes: ainda um desafio para o governo e para a sociedade: LTr, 2006, p. 105.
} 
Neste momento convoca-se a empresa para uma audiência pública, sendo certo que será solicitado um relatório das providências já realizadas e das futuras providências que serão tomadas para a efetiva inserção da pessoa deficiente no mercado de trabalho. Se necessário, será adotado um termo de ajustamento de conduta, sendo expedida a notificação recomendatória. Nota-se que somente após o esgotamento desta tentativa de solução extrajudicial será promovida a ação civil pública. ${ }^{191}$

Cumpre destacar que o ajuizamento da ação civil pública no termos do artigo $3^{\circ}$ da Lei n. 7.853/89 ocorre apenas na hipótese da recusa de adequação legal, sendo cabível a instauração da ação ao MPT da região competente. Nas ações civis públicas, o MPT buscará o cumprimento de uma obrigação de fazer mediante cominação de multas diárias, as quais, em linhas gerais, são estabelecidas em valores elevados com intuito de desestimular o descumprimento da ordem.

De outra esteira, a depender do caso específico, o MPT, ao receber uma denúncia que aborde lesão aos direitos da pessoa com deficiência, pode propor imediatamente uma ação civil pública ou instaurar no âmbito administrativo um inquérito civil público ou procedimento investigatório, buscando a formação de seu convencimento e a instrução da petição inicial com elementos probatórios para a eventual propositura de ação. ${ }^{192}$

Durante o transcorrer do inquérito civil público ou procedimento investigatório, a legislação faculta ao MPT tomar dos inquiridos ou investigados termo de ajustamento de conduta, através do qual se evita o ajuizamento da demanda, sendo certo que deve contar obrigatoriamente uma cominação, normalmente uma multa pecuniária para o caso de descumprimento da obrigação assumida, reversível ao Fundo de Amparo ao Trabalhador (FAT). ${ }^{193}$

O MPT, aliado e atuando em parceria com o MTE, busca alterar o paradigma cultural da exclusão do mercado de trabalho das pessoas deficientes, sendo possível

\footnotetext{
${ }^{191}$ COSTA, Sandra Morais de Brito. Op. cit., p. 204.

${ }^{192}$ LEITE, Carlos Henrique Bezerra. Ministério Público do Trabalho. Op. cit., p. 295.

${ }^{193}$ COSTA, Sandra Morais de Brito. Op. cit., p. 205.
} 
enfatizar que o desconhecimento da capacidade desta categoria de pessoas é o maior obstáculo ao cumprimento da legislação.

Destaca-se que a atuação do MPT é essencial para o Sistema Legal de Reserva de Vagas instituído, representando meio eficaz de fiscalizar o cumprimento da lei. 


\section{OS ASPECTOS DO CONTRATO DE TRABALHO DA PESSOA COM DEFICIÊNCIA}

No presente capítulo, serão abordadas as peculiaridades do contrato de trabalho das pessoas com deficiência no intuito de analisar se a realidade brasileira observa os direitos assegurados pelas leis e pelo texto constitucional vigente, sopesando a existência de meios eficazes de fiscalização e de incentivo e até mesmo a exigência de contratação.

Além disso, serão ventilados os aspectos de maior relevância quanto ao processo seletivo, o ingresso no mercado de trabalho, salário, jornada de trabalho, bem como as peculiaridades atinentes à acessibilidade ao local de trabalho e à adequação do meio ambiente de trabalho às necessidades da pessoa com deficiência.

Por fim, será apontada uma análise estatística sobre o desenvolvimento das atividades profissionais dos trabalhadores com deficiências.

\subsection{Processo seletivo e salário}

O processo de seleção e admissão da pessoa com deficiência é um ponto merecedor de atenção. Ponderando que o mundo contemporâneo deixa claro o culto à beleza e à aparência perfeita, não resta dúvida, por consequência, que a pessoa com deficiência vislumbra inúmeras barreiras para obter uma colocação no mercado de trabalho.

Destaca-se que a Constituição Federal de 1988 prevê expressamente a proibição de toda e qualquer discriminação nos critérios de admissão do trabalhador deficiente. Por esta razão, qualquer discriminação deve ser afastada, desde a entrevista do candidato ao emprego até a rescisão do contrato de trabalho da pessoa com deficiência.

Nota-se que os instrumentos utilizados quando da realização do processo seletivo devem estar disponíveis para as diferentes deficiências, como intérprete de sinais, quando o candidato for pessoa com deficiência auditiva, ou, ainda, teste em braile, para a pessoa com deficiência visual etc. 
Analisando historicamente a legislação brasileira, é possível notar a ausência de obrigatoriedade de contratação de pessoas com deficiências, sendo certo que raras eram as empresas que empregavam esta categoria de pessoas. Assim sendo, é pacífico que, não sendo oferecida oportunidade, de maneira geral, não se pode exigir experiência de uma pessoa deficiente. Portanto, quando a experiência for efetivamente necessária, a própria empresa deverá permitir que a pessoa adquira internamente habilidades, postura de trabalho e os conhecimentos exigidos para o exercício de determinados cargos, segundo entendimento do disposto no artigo 36, alínea "c" da Recomendação n. 168 da OIT. ${ }^{194}$

Seguindo neste mesmo entendimento, não se pode exigir uma escolaridade incompatível com as exigências necessárias ao exercício da função, tendo em vista que historicamente não foram dadas iguais oportunidades de acesso à educação às pessoas com deficiências, sendo certo que, em muitos casos, só tiveram acesso à educação através do apoio de familiares ou da comunidade local.

Nesse caminho, imperioso destacar que o artigo $8^{\circ}$, inciso III, da Lei n. 7.853, de outubro de 1989, tipifica como crime a negativa de emprego ou trabalho, sem justa causa, a alguém, por motivos derivados de sua deficiência, a saber:

Art. $8^{\circ}$ Constitui crime punível com reclusão de 1 (um) a 4 (quatro) anos, e multa:

[...]

III - negar, sem justa causa, a alguém, por motivos derivados de sua deficiência, emprego ou trabalho. ${ }^{195}$

Contudo, necessário observar que, para a caracterização da discriminação quanto aos critérios de admissão e ocorrência da consequente infração ao disposto no texto constitucional e prática de delito penal, se faz necessária a devida comprovação da recusa injustificada e derivada da deficiência, mediante apresentação de provas. ${ }^{196}$

\footnotetext{
${ }^{194}$ COSTA, Sandra Morais de Brito. Op. cit., p. 161.

195 BRASIL. Lei n. 7.853, de 24 de outubro de 1989. Disponível em: <http://www.planalto.gov.br/ccivil_03/leis/L7853compilado.htm>. Acesso em: 22 dez. 2012.

${ }^{196}$ GOLDFARB, Cibelle Linero. Op. cit., p. 156.
} 
Importante mencionar que a empresa, ainda que proceda à contratação da pessoa com deficiência unicamente para fins do cumprimento do disposto em lei, possui a obrigação de dar trabalho.

Neste passo, como bem enfatiza Cristina Abranches Mota Batista:

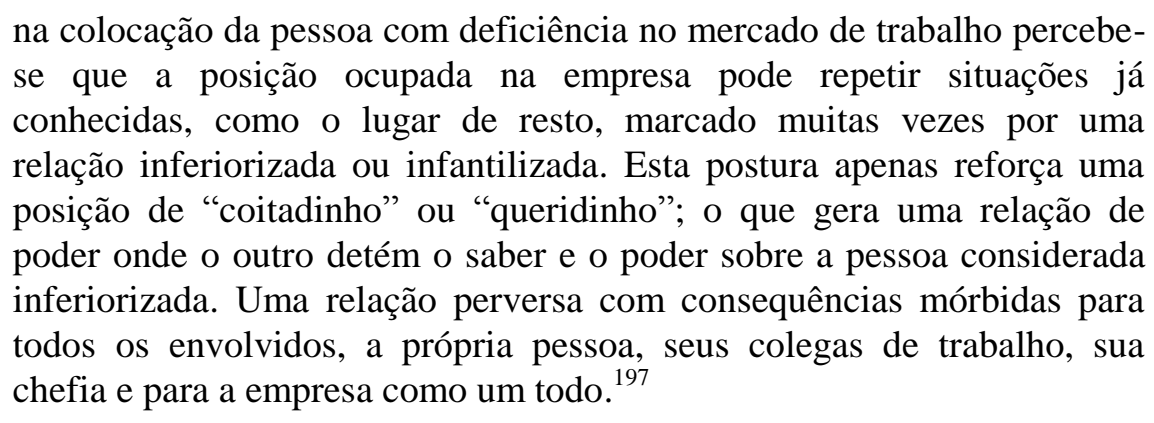

Assim, a empresa deve contratar a pessoa com deficiência para o desenvolvimento das atividades relacionadas à função que ocupará e, ainda, permitir que as atividades sejam desenvolvidas, propiciando os meios necessários, tais como as ferramentas laborais e as adaptações necessárias no local de trabalho.

Independentemente de o empregado ter ou não uma deficiência, cumpre à empresa delegar atividades compatíveis com a sua competência, sempre observando o quanto estipulado no contrato de trabalho, não sendo crível a exigência inferior ou superior às forças do empregado, sob pena de o empregado considerar rescindido o contrato trabalho, de acordo com o disposto no artigo 483 da Consolidação das Leis do Trabalho.

No tocante ao aspecto do salário pago ao empregado com deficiência, assim como mencionado alhures e por força do disposto no artigo $7^{\circ}$, inciso XXXI, da Constituição Federal, não se pode falar em discriminação salarial.

Quanto ao disposto no artigo 461 da Consolidação das Leis do Trabalho (CLT), entende-se ser plenamente aplicável ao contrato de trabalho da pessoa com deficiência, sendo certo que os empregados que desempenham as mesmas atividades, com igual

${ }^{197}$ BATISTA, Cristina Abranches Mota. A inclusão no trabalho. In: BATISTA, Cristina Abranches Mota et al. (Org.). Inclusão dá trabalho. Belo Horizonte: Armazém de Idéias, 2000, p. 35. 
produtividade e perfeição técnica, para o mesmo empregador e na mesma localidade, devem perceber o mesmo salário.

De fato, observa-se a existência de uma lacuna relativa ao fato de o empregado com deficiência ser ou não paradigma ou paragonado para efeito de equiparação salarial; entretanto, não se vislumbra óbice para o pleito de equiparação salarial, desde que atendidos os requisitos legais estipulados no artigo 461 da CLT.

Assim sendo, quanto ao empregado readaptado, tendo em vista o princípio da irredutibilidade salarial, mantida a remuneração anterior ao acidente ou doença profissional ou do trabalho, esta poderá ser superior à paga aos outros empregados que exercem idêntica função, sendo observado o disposto no artigo 461, § $4^{\circ}$, da CLT, in verbis:

Art. 461 - Sendo idêntica a função, a todo trabalho de igual valor, prestado ao mesmo empregador, na mesma localidade, corresponderá igual salário, sem distinção de sexo, nacionalidade ou idade.

[...]

$\S 4^{\mathrm{o}}$ - O trabalhador readaptado em nova função por motivo de deficiência física ou mental atestada pelo órgão competente da Previdência Social não servirá de paradigma para fins de equiparação salarial. ${ }^{198}$

Observando-se o entendimento ora esposado, é plenamente justificável a diferença salarial, razão pela qual não poderá ser reconhecida a equiparação salarial neste particular. Esclarecendo sobre o aspecto ora ventilado, Fernando Américo Veiga Damasceno é de clareza ímpar:

Se este [empregador], na readaptação profissional, não tem liberdade de reduzir o salário da vítima da incapacidade parcial, que passa a cumprir tarefas de qualificação inferior, não se pode exigir o dever de majorar os salários dos demais empregados. A remuneração superior do paradigma não foi estipulada para as funções que exerce após o acidente ou incapacidade de outra origem e, desta forma, o empregador não responderia pelas consequências de natureza isonômica. ${ }^{199}$

Por derradeiro, na hipótese de um empregado readaptado perceber salário inferior a

198 BRASIL. Decreto-Lei n. 5.452, de $\mathbf{1}^{\mathbf{0}}$ de maio de 1943. Disponível em: <http://www.planalto.gov.br/ccivil_03/decreto-lei/Del5452compilado.htm>. Acesso em: 23 dez. 2012.

${ }^{199}$ DAMASCENO, Fernando Américo Veiga. Equiparação salarial. 2. ed. São Paulo: LTr, 1995, p. 148. 
outro empregado que exerça a mesma função e observada a idêntica perfeição técnica e produtividade, nesta situação será facultado o pedido de equiparação salarial.

De outro turno, importante ponderar, ainda, que a regra primordial da inalterabilidade dos contratos de trabalho é absolutamente aplicável quando da contratação de toda e qualquer pessoa com deficiência, devendo ser observado o quanto disposto no artigo 468 da CLT. $^{200}$

Neste caminho, considera-se razoável o entendimento de que, se o empregado com deficiência não venha a se adaptar às atividades para as quais foi inicialmente contratado, bem como, se o próprio empregado deficiente solicitar a alteração de suas atribuições, possível será a alteração do contrato de trabalho para que nova função seja exercida, desde que não exista redução de salário ou implique em prejuízo, direto ou indireto, ao empregado.

\subsection{Estabilidade e jornada de trabalho}

Nota-se, de acordo com o quanto disposto no artigo 93, $\S 1^{\circ}$, da Lei n. 8.213/91, que a dispensa de trabalhador reabilitado ou de deficiente habilitado, ao final de contrato por prazo determinado de mais de noventa dias, e a imotivada, no contrato por prazo indeterminado, só poderá ocorrer após a contratação de substituto de condição semelhante.

Da análise do referido dispositivo, observa-se que a legislação não prevê estabilidade no emprego para a pessoa com deficiência, sendo garantida, tão somente, a reserva de vaga para pessoa em condição semelhante. Neste sentido, o empregador não está impedido de exercer seu direito de demitir a qualquer tempo, desde que observada a contratação de outro profissional com deficiência para preenchimento da reserva prevista em lei.

Desta feita, cumpre mencionar que a previsão ora indicada possui natureza de

200 “Art. 468 - Nos contratos individuais de trabalho só é lícita a alteração das respectivas condições por mútuo consentimento, e ainda assim desde que não resultem, direta ou indiretamente, prejuízos ao empregado, sob pena de nulidade da cláusula infringente desta garantia." 
garantia de emprego e não de estabilidade. Sobre referida diferenciação, Pedro Paulo Teixeira Manus esclarece:

\begin{abstract}
A noção de garantia de emprego é mais ampla do que a idéia de estabilidade. Ao tratar da garantia de emprego podemos cogitar da estabilidade no emprego, ou pensar em outros temas correlatos, mas distintos. Já ao cogitarmos de estabilidade estaremos forçosamente falando de garantia de emprego, pois aquela é um dos aspectos abrangidos pela noção de garantia. Envolve a garantia de emprego a política governamental e a ação sindical tendentes a proporcionar emprego aos trabalhadores. A iniciativa no sentido de tornar mais seguro o posto de trabalho, impedindo dispensas coletivas e imotivadas, além de mecanismos para proporcionar novas colocações aos que, por motivos alheios a sua vontade, encontram-se desempregados. Já a noção de estabilidade diz respeito diretamente ao direito de não perder o emprego, em última análise. Assim, ao se cogitar da garantia de emprego, estamos tratando de conceito mais amplo, que envolve também a noção de estabilidade. As expressões são utilizadas como sinônimos, embora a rigor não sejam. ${ }^{201}$
\end{abstract}

No mesmo caminho o entendimento do doutrinado Maurício Godinho Delgado, devendo ser observada a existência de uma garantia indireta de emprego, posto que se pretende proteger o percentual relativo ao sistema compulsório de cotas. ${ }^{202}$

Frisa-se que a expressão utilizada pelo legislador — "condição semelhante" — deve ser entendida como a contratação de outra pessoa com deficiência ou reabilitada, não sendo necessário ser observada a mesma deficiência do substituído. Da mesma maneira, a substituição pode ser realizada para outra função, sendo o objetivo-fim a contratação de outro empregado deficiente.

No tocante à jornada de trabalho, considerando o disposto no artigo $2^{\circ}$, inciso III, alínea “b”, da Lei n. $7.853 / 89^{203}$ e no artigo 35 , $\S 2^{\circ}$, do Decreto n. $3.298 / 99,{ }^{204}$ a pessoa

\footnotetext{
${ }^{201}$ MANUS, Pedro Paulo Teixeira. Despedida arbitrária ou sem justa causa. São Paulo: Malheiros, 1996, p. 16.

${ }^{202}$ DELGADO, Mauricio Godinho. Curso de Direito do Trabalho. São Paulo: LTr, 2005, p. 1.257.

203 "Art. $2^{\circ}$ - Ao Poder Público e seus órgãos cabe assegurar às pessoas portadoras de deficiência o pleno exercício de seus direitos básicos, inclusive dos direitos à educação, à saúde, ao trabalho, ao lazer, à previdência social, ao amparo à infância e à maternidade, e de outros que, decorrentes da Constituição e das leis, propiciem seu bem-estar pessoal, social e econômico. [...] III - na área da formação profissional e do trabalho: [...] b) o empenho do Poder Público quanto ao surgimento e à manutenção de empregos, inclusive de tempo parcial, destinados às pessoas portadoras de deficiência que não tenham acesso aos empregos comuns."
} 
com deficiência pode ter um horário flexível e reduzido, com salário proporcional, quando necessário, considerando o grau de deficiência.

Neste sentido, o artigo 58-A da Consolidação das Leis do Trabalho dispõe que será considerado trabalho a tempo parcial aquele cuja duração não exceda a 25 horas semanais, sendo que o salário a ser pago aos empregados sob o regime de tempo parcial será proporcional à sua jornada, em relação aos empregados que cumprem, nas mesmas funções, tempo integral. Tais empregados fazem jus a férias proporcionais ao número de horas trabalhadas. $^{205}$

Ao apontar a possibilidade de contratos com jornada reduzida ou trabalho a tempo parcial para os empregados com deficiências, tendo em vista a possibilidade de restrições para o cumprimento de uma jornada integral, verifica-se ser este um meio capaz de viabilizar a inclusão e a manutenção da pessoa com deficiência no mercado de trabalho.

Quanto à jornada variável e ao horário flexível, nota-se que o Decreto n. 3.298 e tampouco a legislação trabalhista apontaram ou descreveram tais modalidades de jornada de trabalho. Portanto, é possível entender que a contratação da pessoa deficiente pode encontrar diferenças no aspecto da fixação da jornada de trabalho, devendo ser considerada a eventual necessidade ou conveniência de se estabelecerem jornadas reduzidas de trabalho. $^{206}$

Alguns aspectos, como a distância da residência até o local de trabalho, a gravidade da deficiência do empregado ou, ainda, a necessidade de tratamento médico continuado, devem ser observados e ponderados quando da fixação da jornada de trabalho diferenciada.

\footnotetext{
204 “Art. 35. São modalidades de inserção laboral da pessoa portadora de deficiência: [...] § 2ํㅡㄹ Consideram-se procedimentos especiais os meios utilizados para a contratação de pessoa que, devido ao seu grau de deficiência, transitória ou permanente, exija condições especiais, tais como jornada variável, horário flexível, proporcionalidade de salário, ambiente de trabalho adequado às suas especificidades, entre outros."

205 “Art. 130-A. Na modalidade do regime de tempo parcial, após cada período de doze meses de vigência do contrato de trabalho, o empregado terá direito a férias, na seguinte proporção: I - dezoito dias, para a duração do trabalho semanal superior a vinte e duas horas, até vinte e cinco horas; II - dezesseis dias, para a duração do trabalho semanal superior a vinte horas, até vinte e duas horas; III - quatorze dias, para a duração do trabalho semanal superior a quinze horas, até vinte horas; IV - doze dias, para a duração do trabalho semanal superior a dez horas, até quinze horas; V - dez dias, para a duração do trabalho semanal superior a cinco horas, até dez horas; VI - oito dias, para a duração do trabalho semanal igual ou inferior a cinco horas."

${ }^{206}$ GOLDFARB, Cibelle Linero. Op. cit., p. 164.
} 
Importante destacar, conforme previsto no artigo 473 da Consolidação das Leis do Trabalho, que existe previsão para algumas hipóteses de faltas justificadas ao trabalho; entretanto, não existe qualquer previsão específica quanto à possibilidade de o empregado deficiente se ausentar do trabalho para a realização de consultas médicas ou tratamentos relacionados com a sua deficiência.

Contudo, apesar da ausência de previsão na legislação brasileira, as faltas injustificadas ou licenças especiais podem ser implementadas pelas empresas através de seus regulamentos internos ou, ainda, por meio da atuação dos sindicatos e da inserção de normas nos instrumentos coletivos de trabalho. ${ }^{207}$

\subsection{Análise de dados estatísticos}

No presente tópico serão analisados os resultados apontados pelo Censo Demográfico 2010 e divulgados pelo Instituto Brasileiro de Geografia e Estatística $\mathrm{IBGE}^{208}$ no tocante à pessoa com deficiência.

De acordo com as informações apontadas pelo referido estudo, ${ }^{209}$ o conceito de deficiência sofreu inúmeras modificações para acompanhar as inovações na área da saúde e a forma com que a sociedade se relaciona com a parcela da população que apresenta algum tipo de deficiência.

O estudo aborda, ainda, que a investigação do tema "pessoas com deficiência" também sofreu modificações ao longo dos levantamentos censitários para se adequar a essa evolução do conceito de deficiência. Além de no Censo Demográfico 2010, o tema esteve presente no primeiro levantamento censitário brasileiro, em 1872, e nos Censos Demográficos 1890, 1900, 1920, 1940, 1991 e 2000; porém, com mudanças nos conceitos

\footnotetext{
${ }^{207}$ GOLDFARB, Cibelle Linero. Op. cit., p. 166.

${ }^{208}$ INSTITUTO BRASILEIRO DE GEOGRAFIA E ESTATÍSTICA - IBGE. Censo Demográfico 2010. Disponível em: <ftp://ftp.ibge.gov.br/Censos/Censo_Demografico_2010/Trabalho_e_Rendimento/censo_ trabalho_e_rendimento.pdf $>$. Acesso em: 27 dez. 2012.

${ }^{209}$ INSTITUTO BRASILEIRO DE GEOGRAFIA E eSTATÍsTICA- IBGE. Censo Demográfico 2010. Disponível em: <http://censo2010.ibge.gov.br/resultados〉. Acesso em: 27 dez. 2012.
} 
utilizados ou na formulação das perguntas, o que não permite a comparabilidade direta entre esses levantamentos.

Cumpre esclarecer que, no Censo Demográfico 2010, as perguntas formuladas buscaram identificar as deficiências visual, auditiva e motora, com seus graus de severidade, através da percepção da população sobre sua dificuldade em enxergar, ouvir e locomover-se, mesmo com o uso de facilitadores como óculos ou lentes de contato, aparelho auditivo ou bengala, e sobre a deficiência mental ou intelectual. A investigação dos graus de severidade de cada deficiência permitiu conhecer a parcela da população com deficiência severa, que se constitui no principal alvo das políticas públicas voltadas para a população com deficiência.

De acordo com as linhas traçadas pelo Instituto Brasileiro de Geografia e Estatística - IBGE, foram considerados como deficiência severa visual, auditiva e motora os casos em que as pessoas declararam ter grande dificuldade para ver, ouvir ou se locomover ou em que não conseguiam ver, ouvir ou se locomover de modo algum, tendo sido também considerados os casos em que as pessoas declararam ter deficiência mental ou intelectual.

Os resultados do Censo Demográfico 2010 apontaram 45.606.048 milhões de pessoas que declararam ter pelo menos uma das deficiências investigadas, correspondendo a 23,9\% da população brasileira. Desta totalidade, 38.473 .702 se encontravam em áreas urbanas e 7.132.347, em áreas rurais. É possível constatar que a Região Nordeste concentra os municípios com os maiores percentuais da população com pelo menos uma das deficiências investigadas, conforme ilustra o Mapa 1, abaixo. 


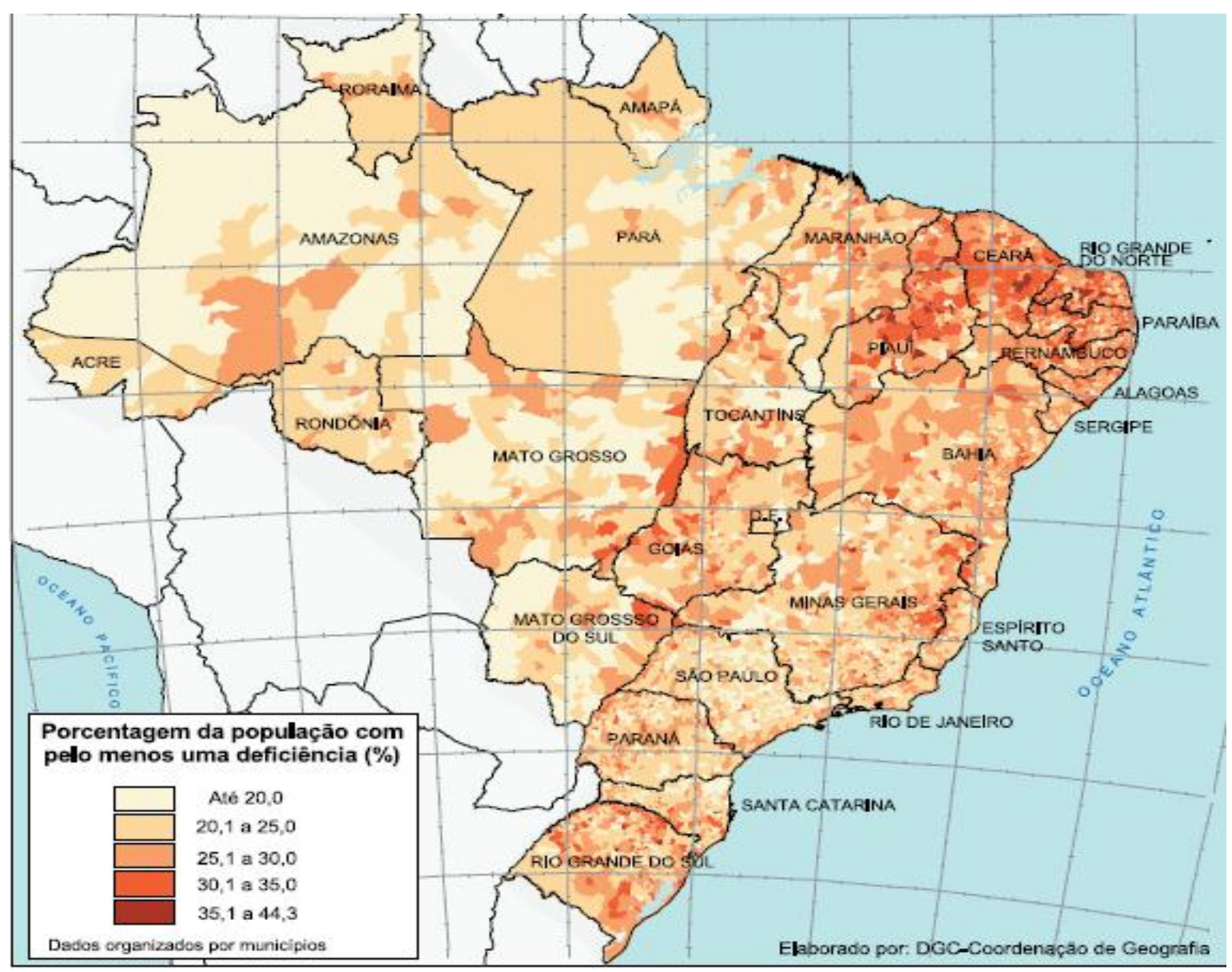

Mapa 1 - Percentual de pessoas com pelo menos uma das deficiências investigadas na população residente dos municípios (IBGE, Censo Demográfico 2010)

Apesar da perceptível concentração de municípios com maiores percentuais de população com deficiência na Região Nordeste, observou-se que em todas as Unidades da Federação havia municípios com percentual de pessoas com pelo menos uma das deficiências investigadas acima da média nacional, com destaque para o estado do Rio Grande do Norte, onde 12,0\% de seus municípios apresentaram percentual de pessoas com pelo menos uma das deficiências investigadas acima de 35,0\%. 


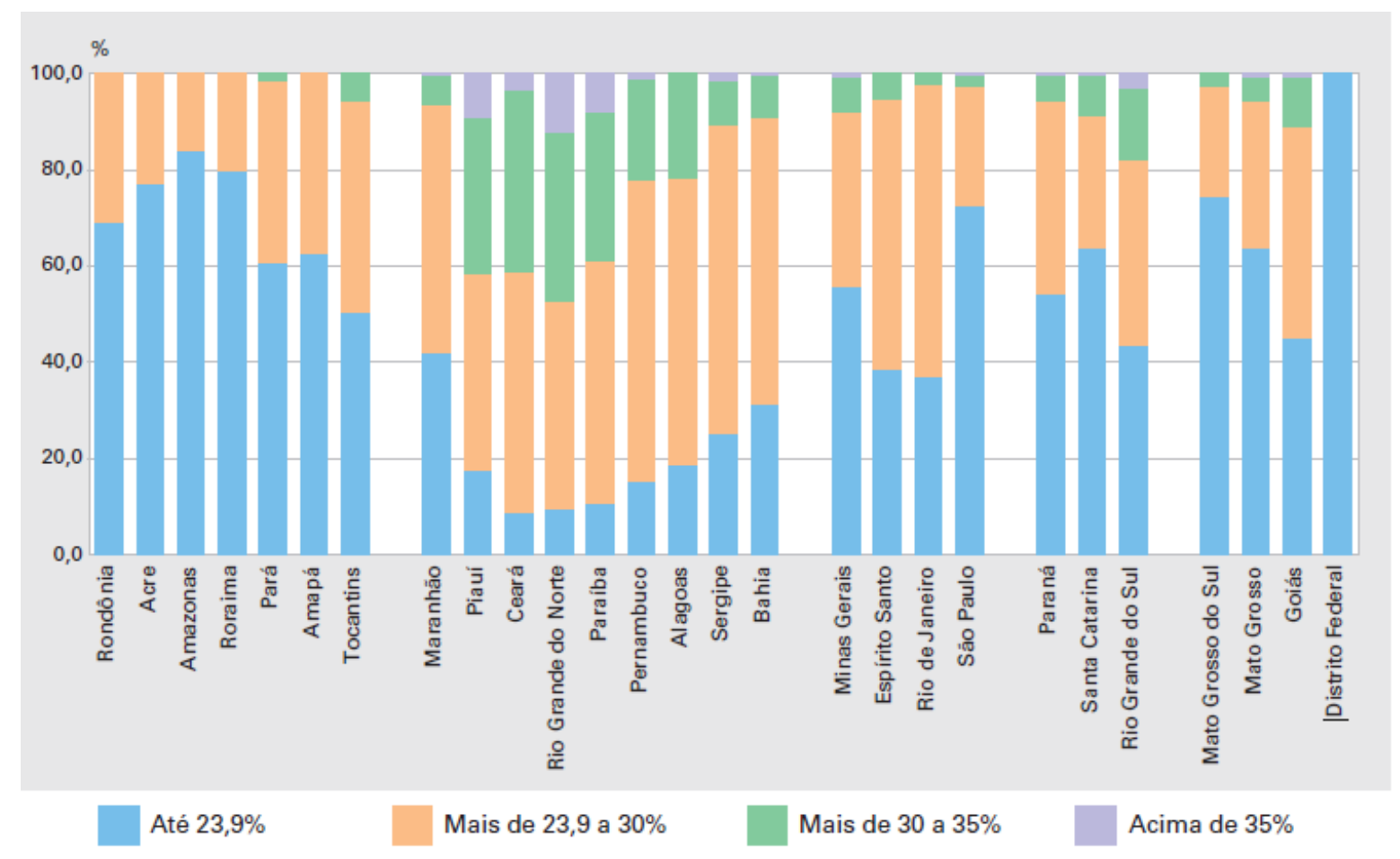

Gráfico 1 - Distribuição dos municípios, por grupos de percentual de pessoas com pelo menos uma das deficiências investigadas na população residente, segundo Unidades da Federação (IBGE, Censo Demográfico 2010)

Em relação à proporção de pessoas com pelo menos uma das deficiências investigadas, segundo os grupos de idade, o estudo constatou que $7,5 \%$ das crianças de 0 a 14 anos de idade apresentaram pelo menos um tipo de deficiência. A prevalência de pelo menos uma das deficiências investigadas foi maior (24,9\%) na população de 15 a 64 anos de idade e atingiu mais da metade da população de 65 anos ou mais de idade (67,7\%). Esse aumento proporcional da prevalência de deficiência em relação à idade advém provavelmente das limitações do próprio fenômeno do envelhecimento, onde há uma perda gradual da acuidade visual e auditiva e da capacidade motora do indivíduo, conforme indicado no Gráfico 2, abaixo. 


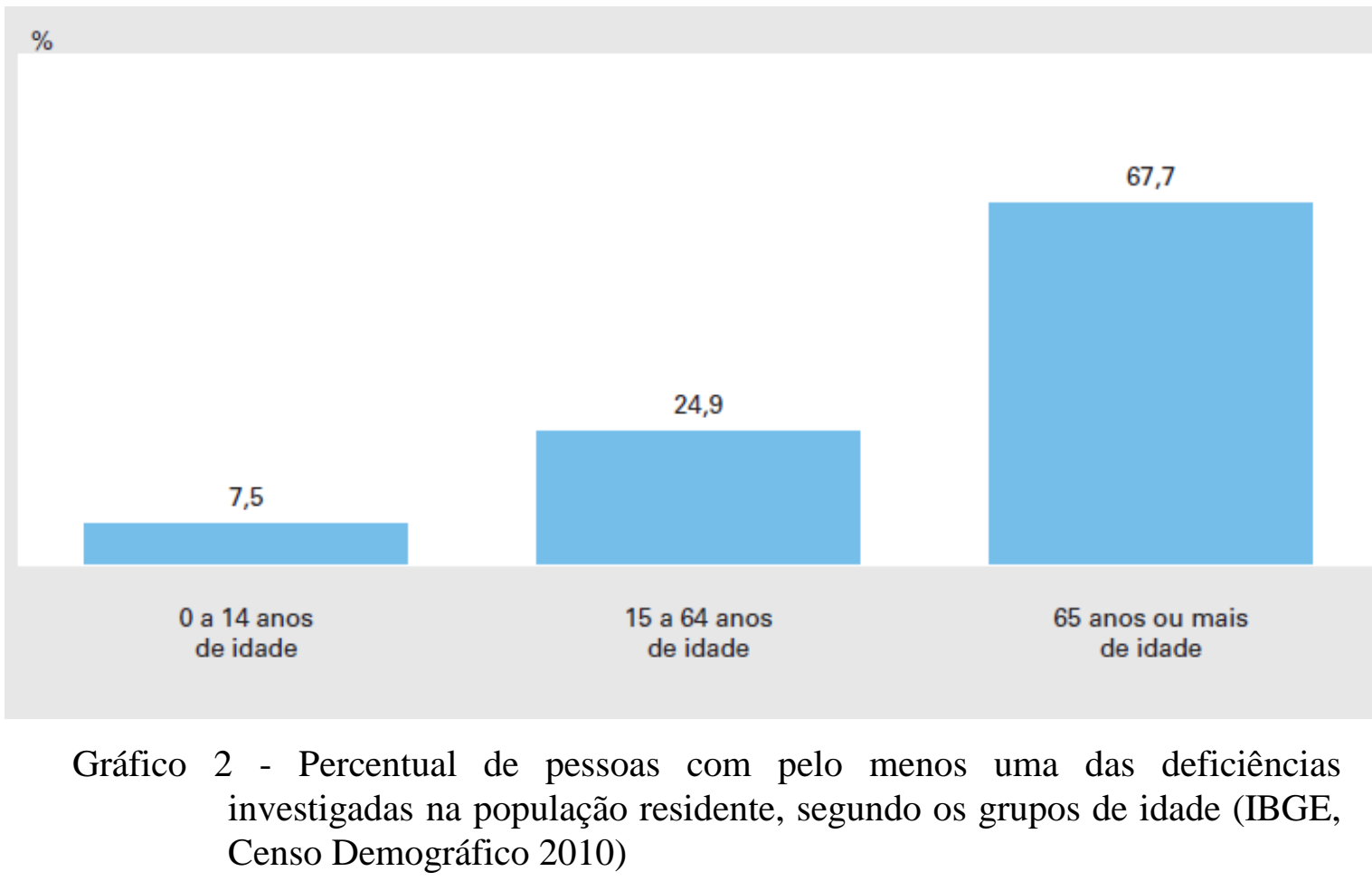

Outro aspecto da pesquisa que merece ser destacado refere-se ao percentual de deficiência em razão do sexo. O percentual da população feminina com pelo menos uma das deficiências investigadas foi de 26,5\%, correspondendo a 25.800.681 mulheres. Esse percentual é superior ao da população masculina com pelo menos uma deficiência, que foi de 21,2\%, correspondendo a 19.805.367 homens. A análise pelos grandes grupos de idade mostrou que, para a população de 0 a 14 anos de idade, apenas na deficiência visual a população feminina apresentou um maior percentual de deficiência $(5,9 \%)$ em comparação com a população masculina $(4,8 \%)$. Para a deficiência visual no grupo de 15 a 64 anos de idade, o percentual de população feminina $(23,1 \%)$ também superou o percentual de população masculina $(17,1 \%)$. Situação semelhante ocorreu para a deficiência motora, na qual $6,8 \%$ da população feminina apresentava deficiência motora, contra 4,5\% da população masculina.

Segundo as linhas traçadas pelo estudo e tendo em vista que a população brasileira está em processo de envelhecimento, bem como que a mortalidade masculina é superior à feminina, especialmente nas idades avançadas, a população de 65 anos ou mais de idade com pelo menos uma deficiência teve maior peso entre as mulheres do que entre os homens. Os percentuais de deficiência entre as mulheres desse grupo etário superaram os 
dos homens para as deficiências visual, motora e mental. A deficiência auditiva foi declarada por 28,2\% dos homens de 65 anos ou mais de idade, enquanto 23,6\% das mulheres desse grupo etário declararam ter o mesmo tipo de deficiência.

Tabela 1 - Distribuição percentual da população residente, por tipo de deficiência, segundo o sexo e os grupos de idade (IBGE, Censo Demográfico 2010)

\begin{tabular}{|c|c|c|c|c|c|c|c|}
\hline \multirow[b]{3}{*}{$\begin{array}{c}\text { Sexo } \\
\Theta \\
\text { grupos de idade }\end{array}$} & \multicolumn{7}{|c|}{ Distribuição percentual da população residente (\%) } \\
\hline & \multirow[b]{2}{*}{$\begin{array}{l}\text { Total } \\
\text { (1) (2) }\end{array}$} & \multicolumn{6}{|c|}{ Tipo de deficiência } \\
\hline & & $\mid \begin{array}{c}\text { Pelo menos } \\
\text { uma das } \\
\text { deficiências } \\
\text { enumeradas } \\
\text { (1) }\end{array}$ & Visual & Auditiva & Motora & $\begin{array}{l}\text { Mental ou } \\
\text { intelctual }\end{array}$ & $\begin{array}{l}\text { Nenhuma } \\
\text { destas } \\
\text { deficiências } \\
\text { (3) }\end{array}$ \\
\hline Total & 100,0 & 23,9 & 18,8 & 5,1 & 7,0 & 1,4 & 76,1 \\
\hline 0 a 14 anos & 100,0 & 7,5 & 5,3 & 1,3 & 1,0 & 0,9 & 92,5 \\
\hline 15 a 64 anos & 100,0 & 24,9 & 20,1 & 4,2 & 5,7 & 1,4 & 75,0 \\
\hline 65 anos ou mais & 100,0 & 67,7 & 49,8 & 25,6 & 38,3 & 2,9 & 32,3 \\
\hline Homens & 100,0 & 21,2 & 16,0 & 5,3 & 5,3 & 1,5 & 78,8 \\
\hline 0 a 14 anos & 100,0 & 7,3 & 4,8 & 1,4 & 1,0 & 1,0 & 92,7 \\
\hline 15 a 64 anos & 100,0 & 22,2 & 17,1 & 4,5 & 4,5 & 1,6 & 77,8 \\
\hline 65 anos ou mais & 100,0 & 64,6 & 47,3 & 28,2 & 30,9 & 2,8 & 35,4 \\
\hline Mulheres & 100,0 & 26,5 & 21,4 & 4,9 & 8,5 & 1,2 & 73,5 \\
\hline 0 a 14 anos & 100,0 & 7,8 & 5,9 & 1,3 & 1,0 & 0,7 & 92,2 \\
\hline 15 a 64 anos & 100,0 & 27,6 & 23,1 & 4,0 & 6,8 & 1,2 & 72,4 \\
\hline 65 anos ou mais & 100,0 & 70,1 & 51,7 & 23,6 & 44,0 & 3,0 & 29,9 \\
\hline
\end{tabular}

(1) As pessoas incluidas em mais de um tipo de deficiência foram contadas apenas uma vez. (2) Inclusive as pessoas sem declaraçäo destas deficiências. (3) Inclusive a populaçäo sem qualquer tipo de deficiência.

No tocante à cor ou raça, o maior percentual de pessoas com pelo menos uma das deficiências investigadas se encontrava na população que se declarou preta $(3.884 .965$ pessoas) ou amarela (569.838 pessoas), ambas com 27,1\%, enquanto que o menor percentual foi o da população indígena, com 20,1\%, correspondendo a 165.148 pessoas. Por outro lado, a população feminina apresentou percentuais de pelo menos uma das deficiências superiores aos dos homens para qualquer cor ou raça declarada, sendo a maior diferença encontrada entre as mulheres e os homens de cor preta, de 7,3 pontos percentuais, e a menor diferença, de 3,4 pontos percentuais, entre os homens e mulheres indígenas. 


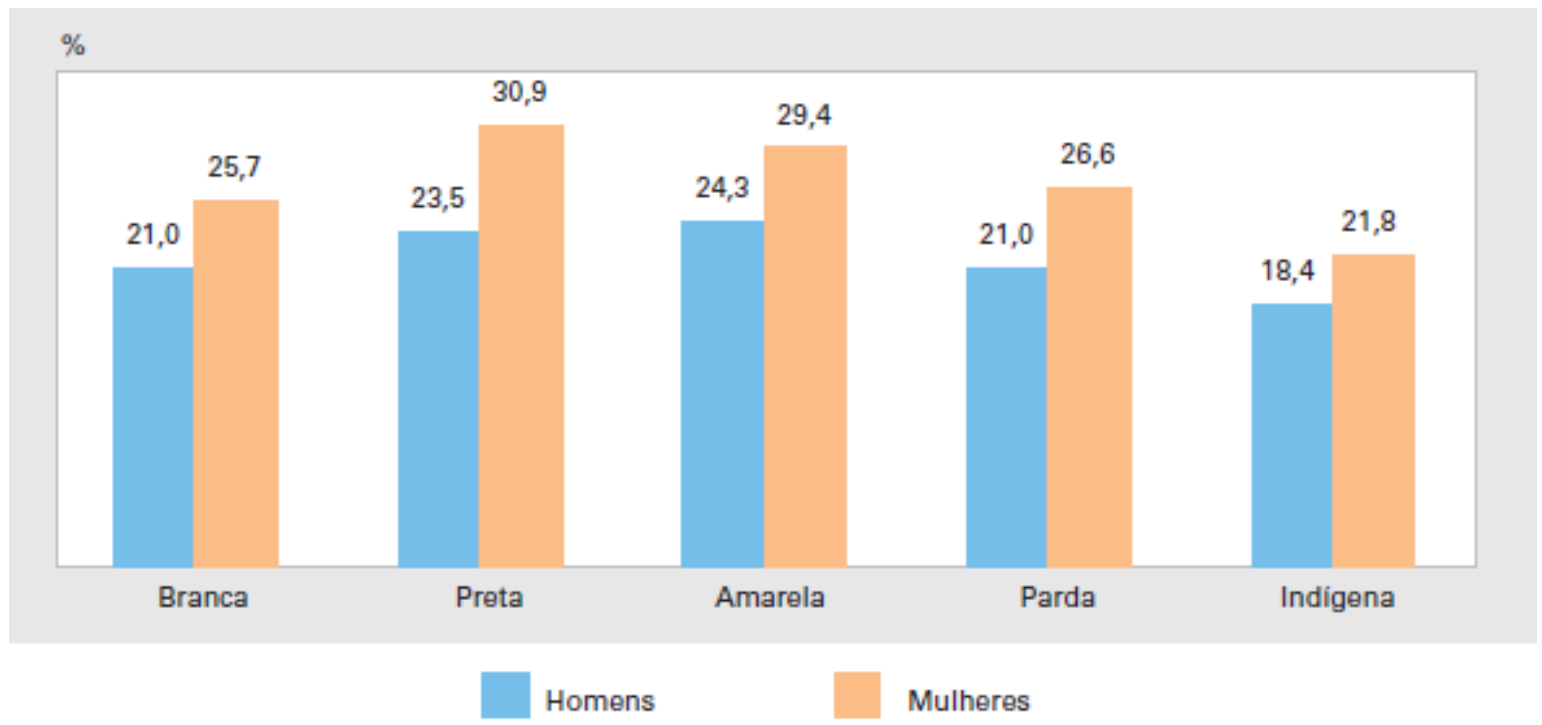

Gráfico 3 - Percentual de pessoas com pelo menos uma das deficiências investigadas na população residente, por sexo, segundo a cor ou raça (IBGE, Censo Demográfico 2010)

Conforme mencionado anteriormente, a investigação da deficiência no Censo Demográfico 2010 se baseou na percepção do indivíduo sobre sua dificuldade em enxergar, ouvir ou se locomover, e na existência de deficiência mental ou intelectual. Assim, essa percepção também está relacionada com sua interação com o ambiente em que o indivíduo está inserido, bem como com as condições econômicas e sociais que o cercam.

Nota-se que referida relação tornou-se mais clara quando da na análise da população com pelo menos uma das deficiências investigadas em nível regional, onde as populações amarela e preta da Região Nordeste apresentaram os maiores percentuais (30,6\% e 29,8\%, respectivamente), seguidas da população indígena da Região Sudeste. Por outro lado, as populações indígenas das Regiões Norte e Centro-Oeste detiveram os menores percentuais de pessoas com pelo menos uma deficiência (14,3\% e 14,5\%, respectivamente). 
Tabela 2 - Percentual de pessoas com pelo menos uma das deficiências investigadas na população residente, segunda as Grandes Regiões (IBGE, Censo Demográfico 2010)

\begin{tabular}{|c|c|c|c|c|c|c|}
\hline \multirow{3}{*}{ Grandes Regiöes } & \multicolumn{6}{|c|}{$\begin{array}{l}\text { Percentual de pessoas com pelo menos uma das } \\
\text { deficiências investigadas na população residente (\%) (1) }\end{array}$} \\
\hline & \multirow{2}{*}{ Total } & \multicolumn{5}{|c|}{ Cor ou raça } \\
\hline & & Branca & Preta & Amarela & Parda & Indigena \\
\hline Brasil & 23,9 & 23,5 & 27,1 & 27,1 & 23,8 & 20,1 \\
\hline Norte & 23,0 & 23,8 & 27,3 & 25,6 & 22,6 & 14,3 \\
\hline Nordeste & 26,6 & 26,8 & 29,8 & 30,6 & 26,0 & 27,3 \\
\hline Sudeste & 23,0 & 22,9 & 25,4 & 26,3 & 22,5 & 29,3 \\
\hline Sul & 22,5 & 22,3 & 24,8 & 24,2 & 22,6 & 21,1 \\
\hline Centro-Oeste & 22,5 & 22,5 & 25,8 & 23,6 & 22,1 & 14,5 \\
\hline
\end{tabular}

(1) As pessoas incluidas em mais de um tipo de deficiência foram contadas apenas uma vez.

Os resultados do Censo Demográfico 2010 mostraram diferenças significativas entre o nível de instrução das pessoas com pelo menos uma das deficiências investigadas e o daquelas sem deficiências. Se por um lado $61,1 \%$ da população de 15 anos ou mais de idade com deficiência não tinha instrução ou possuía apenas o fundamental incompleto, esse percentual era de 38,2\% para as pessoas de 15 anos ou mais que declararam não ter nenhuma deficiência, representando uma diferença de 22,9 pontos percentuais. A segunda maior diferença em pontos percentuais foi observada para o ensino médio completo e para o superior incompleto, onde o percentual de população de 15 anos ou mais com deficiência foi de $17,7 \%$ contra $29,7 \%$ para as pessoas sem deficiência. Observou-se ainda a existência da menor diferença no tocante ao ensino superior completo: $6,7 \%$ para a população de 15 anos ou mais com deficiência e 10,4\% para a população sem deficiência. 


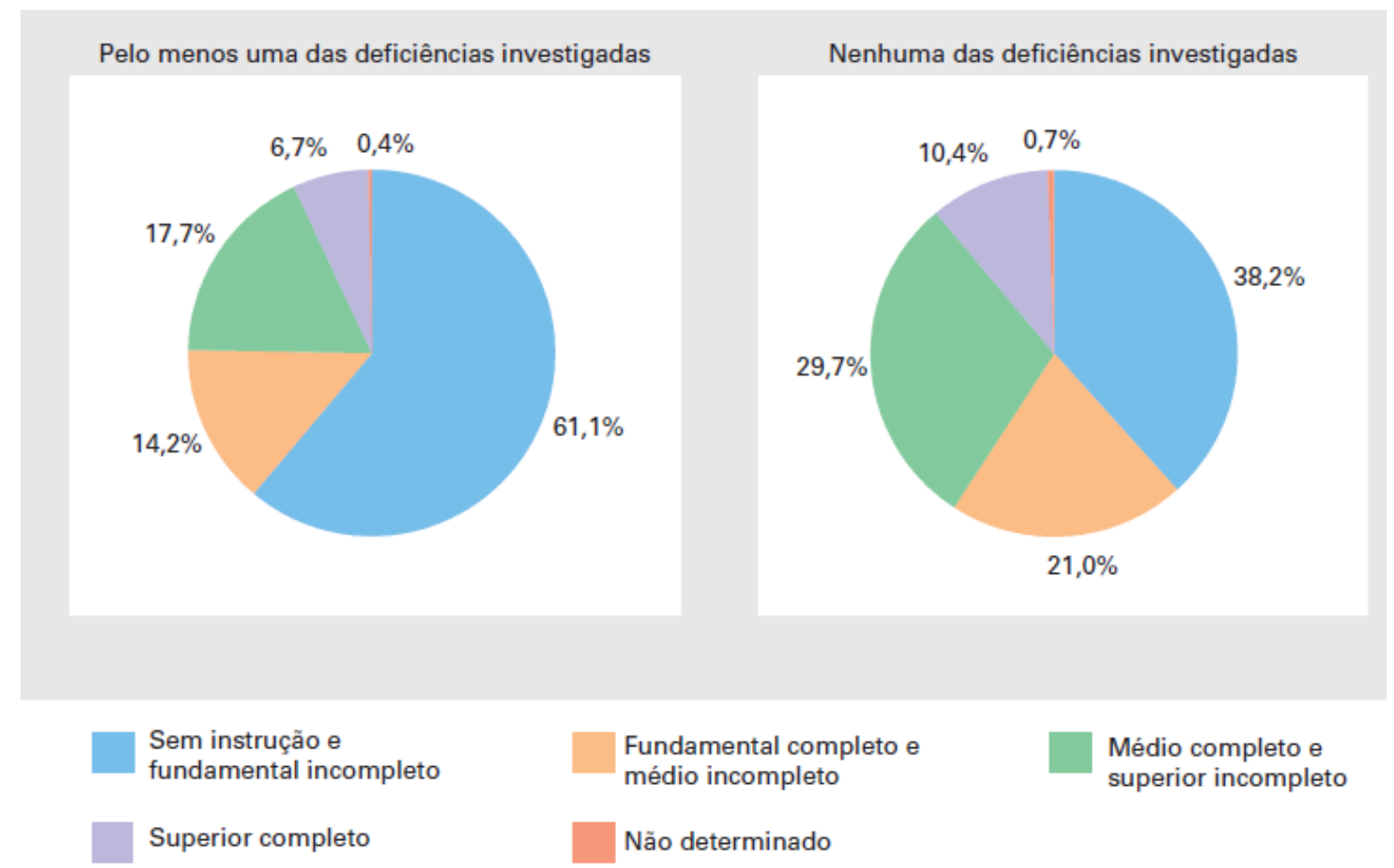

Gráfico 4 - Distribuição percentual da população de 15 anos ou mais de idade, por existência de pelo menos uma das deficiências investigadas e nível de instrução (IBGE, Censo Demográfico 2010)

Nota-se que, para as grandes regiões, observou-se que a distribuição da população de 15 anos ou mais de idade com pelo menos uma das deficiências investigadas por nível de instrução seguiu o comportamento do Brasil, com a maior diferença observada entre as Regiões Nordeste $(67,7 \%)$ e Sudeste $(56,2 \%)$ para sem instrução ou com ensino fundamental incompleto. Para os demais níveis de instrução, essa diferença não ultrapassou cinco pontos percentuais. Destaca-se ainda a Região Sudeste, onde 8,5\% da população de 15 anos ou mais com pelo menos uma das deficiências investigadas tinha ensino superior completo. 
Tabela 3 - Distribuição percentual das pessoas de 15 anos ou mais de idade com pelo menos uma das deficiências investigadas, por nível de instrução, segundo as Grandes Regiões (IBGE, Censo Demográfico 2010)

\begin{tabular}{|c|c|c|c|c|c|c|}
\hline \multirow{3}{*}{ Grandes Regióes } & \multicolumn{6}{|c|}{$\begin{array}{l}\text { Distribuiçáo percentual das pessoas de } 15 \text { anos ou mais de idade com } \\
\text { pelo menos uma das deficiências investigadas (\%) (1) }\end{array}$} \\
\hline & \multirow[b]{2}{*}{ Total } & \multicolumn{5}{|c|}{ Nivel de instruçăo } \\
\hline & & $\begin{array}{c}\text { Sem instruçáo } \\
\text { e fundamental } \\
\text { incompleto }\end{array}$ & $\begin{array}{l}\text { Fundamental } \\
\text { completo e } \\
\text { médio } \\
\text { incompleto }\end{array}$ & $\begin{array}{l}\text { Médio } \\
\text { completo e } \\
\text { superior } \\
\text { incompleto }\end{array}$ & $\begin{array}{l}\text { Superior } \\
\text { completo }\end{array}$ & $\begin{array}{c}\text { Năo } \\
\text { determinado }\end{array}$ \\
\hline Brasil & 100,0 & 61,1 & 14,2 & 17,7 & & 0,4 \\
\hline Norte & 100,0 & 61,9 & 14,0 & 18, & & 0,4 \\
\hline Nordeste & 100,0 & 67,7 & 12,3 & 15,7 & & 0,3 \\
\hline Sudeste & 100,0 & 56,2 & 15,5 & 19, & & 0,5 \\
\hline Sul & 100,0 & 62,6 & 14,4 & $16, \mathrm{C}$ & & 0,2 \\
\hline Centro-Oeste & 100,0 & 58,4 & 14,3 & 18,7 & & 0,4 \\
\hline
\end{tabular}

(1) As pessoas incluídas em mais de um tipo de deficiência foram contadas apenas uma vez.

Por derradeiro, para avaliar a inserção da pessoa com deficiência no mercado de trabalho, foi utilizada como indicador a taxa de atividade, que é o percentual de pessoas economicamente $\operatorname{ativas}^{210}$ na população de 10 ou mais anos de idade.

Considerando as taxas de atividade por sexo, observou-se que a condição de deficiência como fator limitante para a inserção da pessoa com deficiência no mercado de trabalho atinge mais a população masculina do que a feminina.

\footnotetext{
${ }^{210}$ Segundo as informações apontadas pelo IBGE, considerou-se como economicamente ativa na semana de referência a pessoa ocupada ou desocupada nessa semana. Considerou-se como ocupada na semana de referência a pessoa que exerceu algum trabalho durante pelo menos uma hora completa nessa semana, ou a pessoa que tinha trabalho remunerado do qual estava temporariamente afastada nessa semana. Considerou-se como ocupada temporariamente afastada de trabalho remunerado a pessoa que não trabalhou durante pelo menos uma hora completa na semana de referência por motivo de férias, licença remunerada pelo empregador ou por instituto de previdência, falta voluntária ao trabalho, greve, suspensão temporária do contrato de trabalho, doença, más condições do tempo, quebra de máquina, limitação de produção ou qualquer outro impedimento independente da sua vontade. E considerou-se como desocupada a pessoa sem trabalho na semana de referência, mas que estava disponível para assumir um trabalho nessa semana e que tomou alguma providência efetiva para conseguir trabalho no período de referência de trinta dias, sem ter tido qualquer trabalho ou após ter saído do último trabalho que teve nesse período. Segundo as informações apontadas pelo IBGE, a investigação das características de trabalho teve como semana de referência a semana de 25 a 31 de julho de 2010. (INSTITUTO BRASILEIRO DE GEOGRAFIA E ESTATÍSTICA- IBGE. Censo Demográfico 2010. Disponível em: 〈http://censo2010.ibge.gov.br/resultados〉. Acesso em: 27 dez. 2012).
} 


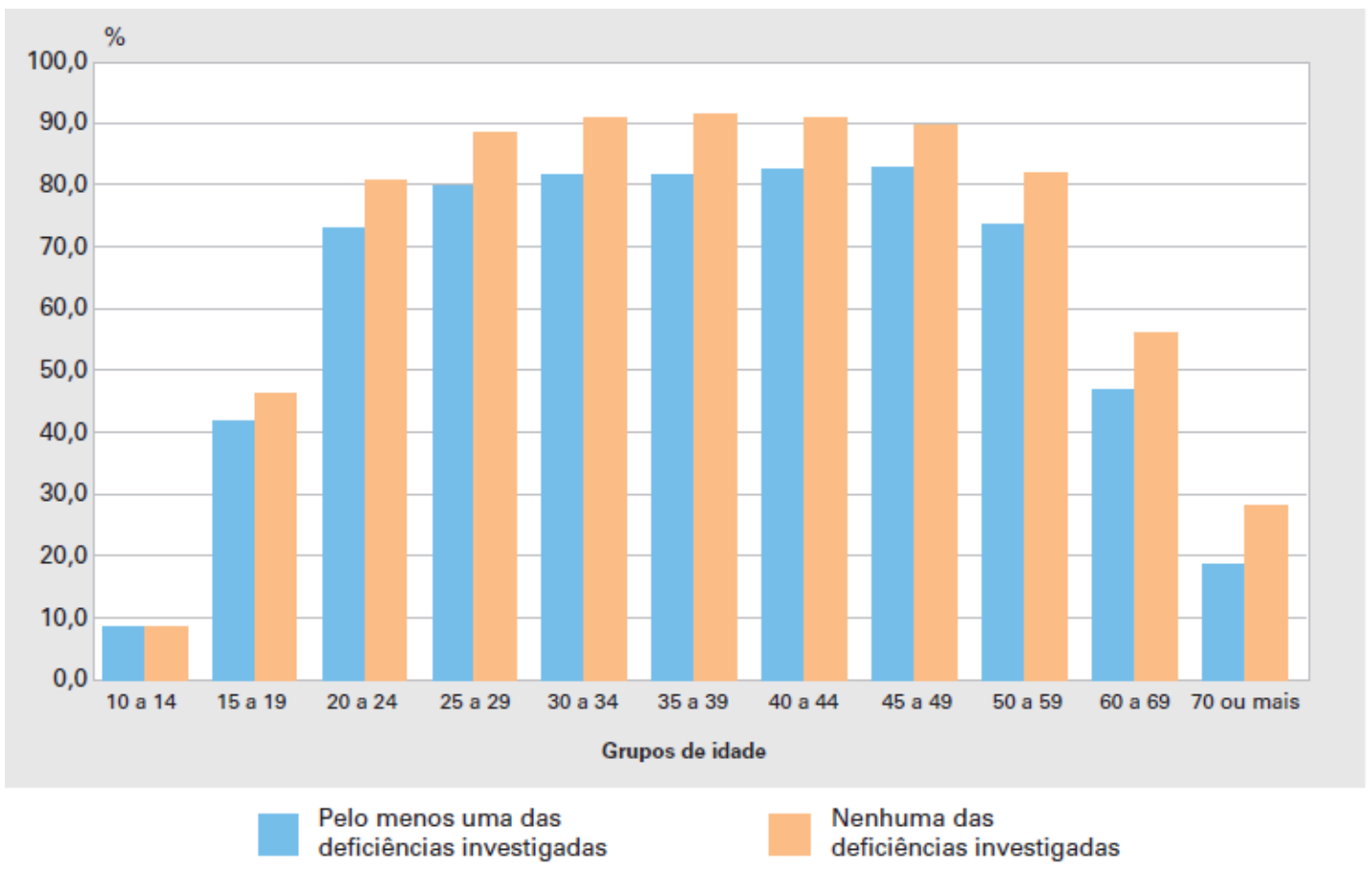

Gráfico 5 - Taxa de atividade da população masculina de 10 anos ou mais de idade, por existência de pelo menos uma das deficiências investigadas, segundo os grupos de idade (IBGE, Censo Demográfico 2010)

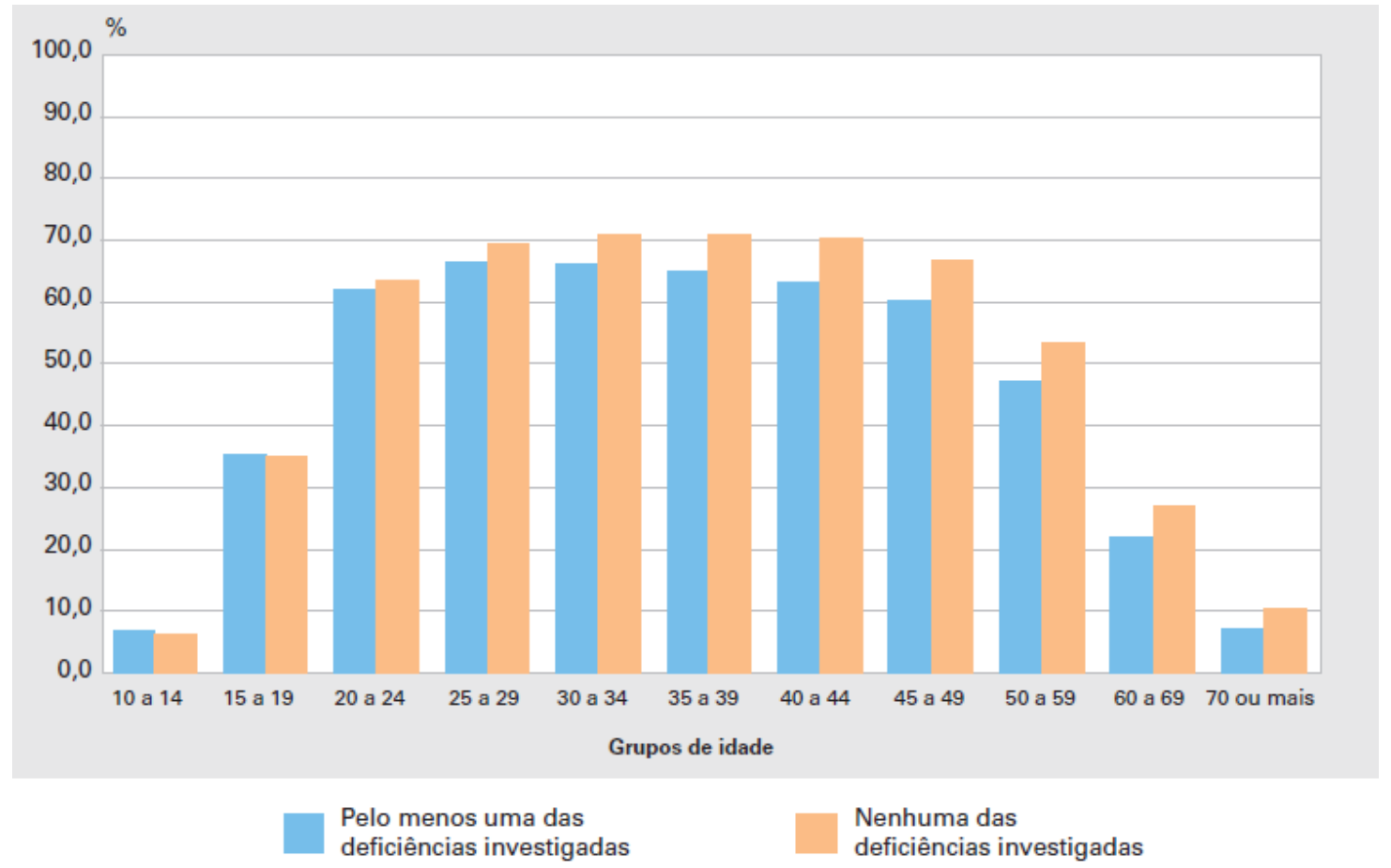

Gráfico 6 - Taxa de atividade da população feminina de 10 anos ou mais de idade, por existência de pelo menos uma das deficiências investigadas, segundo os grupos de idade (IBGE, Censo Demográfico 2010) 
Comparando as taxas de atividade por tipo de deficiência investigada, observou-se que a deficiência mental ou intelectual exerceu maior influência sobre a participação na força de trabalho tanto para a população masculina quanto para a feminina. A deficiência motora também atuou como um fator limitante, porém as diferenças entre as taxas de atividade de homens com deficiência motora e com deficiência auditiva foram maiores do que aquelas observadas para as mulheres de mesma condição.

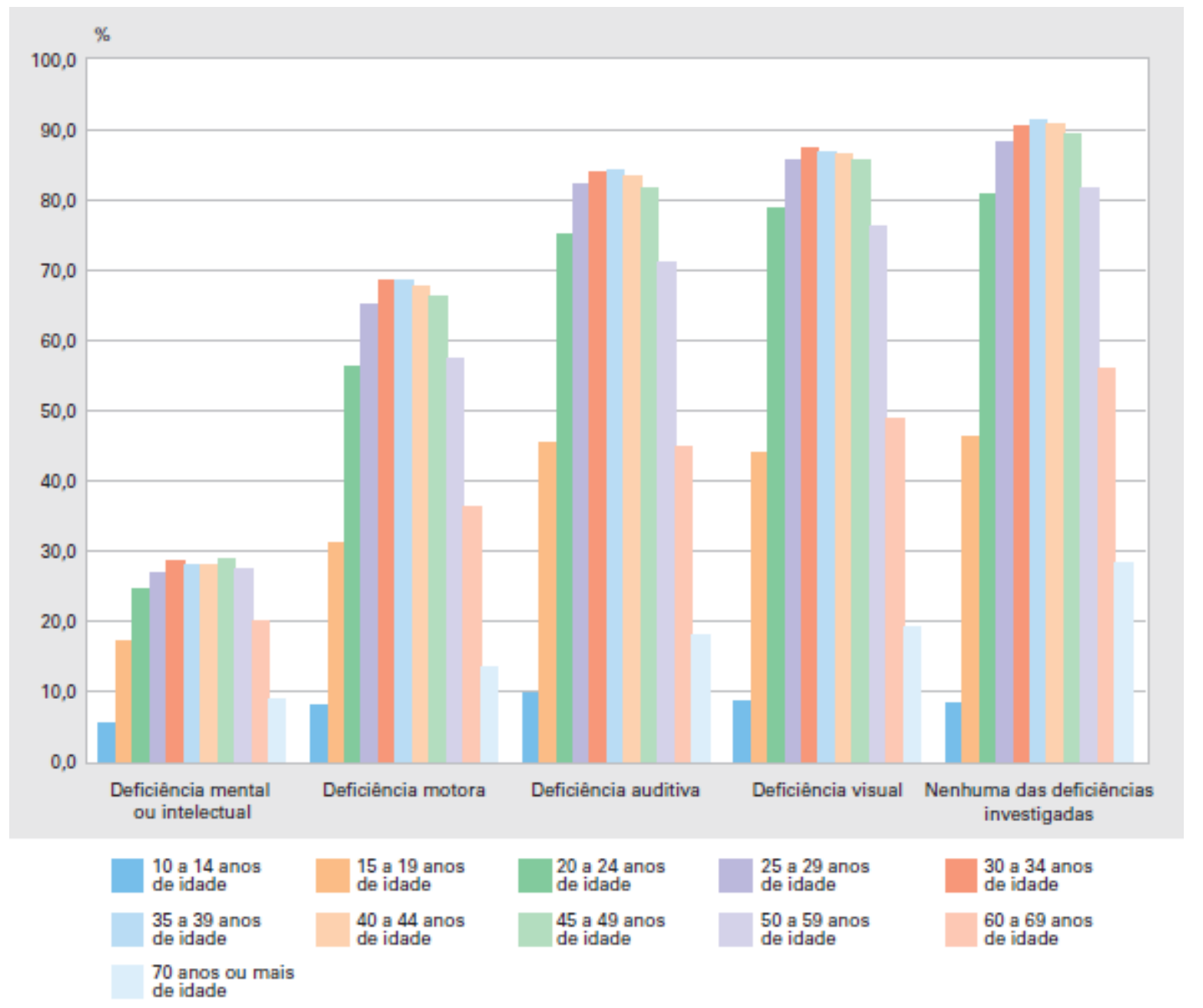

Gráfico 7 - Taxa de atividade da população masculina de 10 anos ou mais de idade, por grupos de idade, segundo o tipo de deficiência investigada (IBGE, Censo Demográfico 2010) 


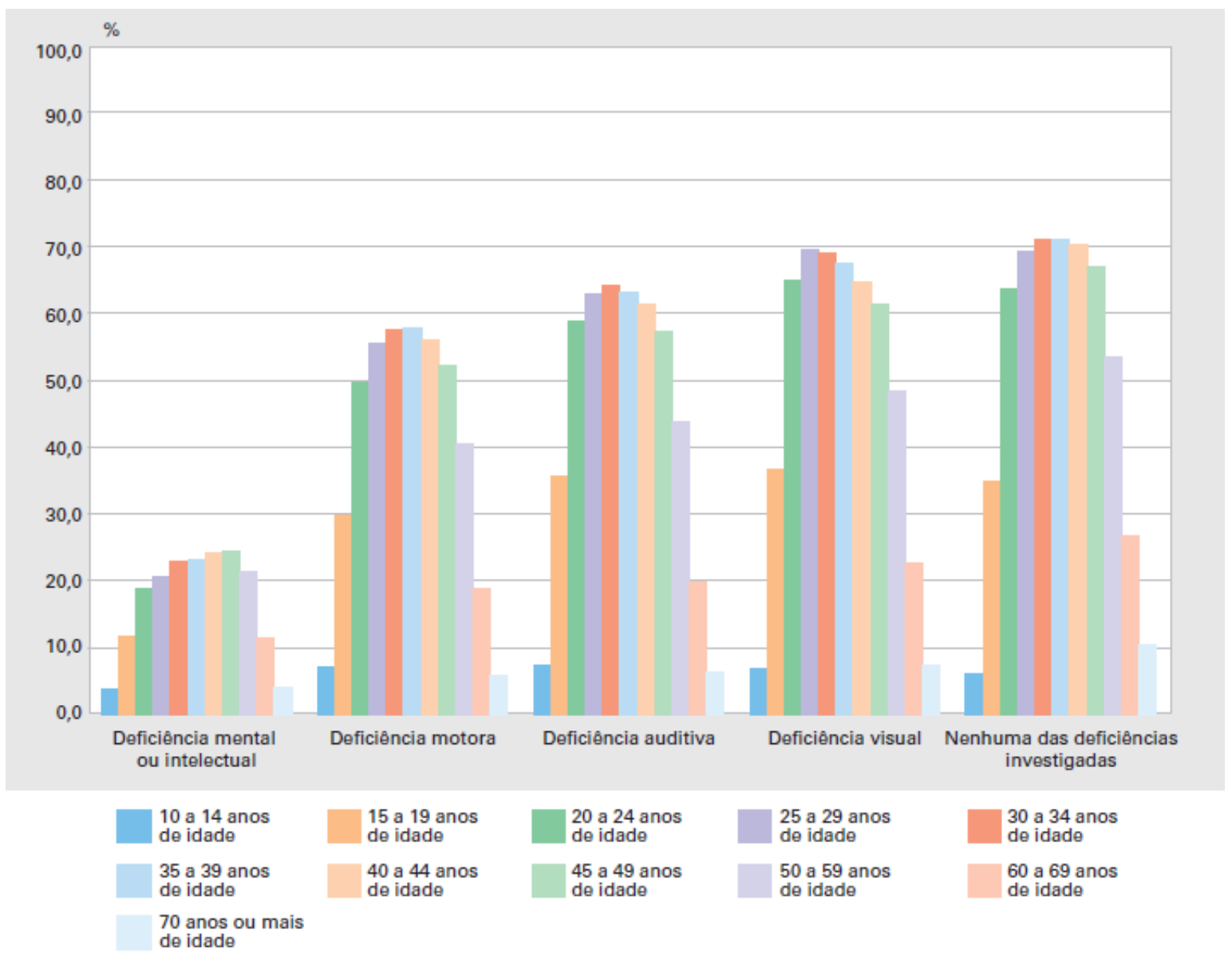

Gráfico 8 - Taxa de atividade da população feminina de 10 anos ou mais de idade, por grupos de idade, segundo o tipo de deficiência investigada (IBGE, Censo Demográfico 2010)

Outro indicador importante é o nível de ocupação, ou seja, o percentual de pessoas ocupadas na semana de referência ${ }^{211}$ na população de 10 anos ou mais de idade.

Nota-se que o tipo de deficiência também exerceu influência no nível de ocupação das pessoas de 10 anos ou mais de idade, sendo que a deficiência mental apresentou os menores níveis de ocupação. Cumpre destacar que a diferença por sexo foi mais evidente nas deficiências visual e auditiva, alcançando a ordem de 20,8 pontos percentuais.

${ }^{211}$ Segundo as informações apontadas pelo IBGE, a investigação das características de trabalho teve como semana de referência a semana de 25 a 31 de julho de 2010 . 
$\%$

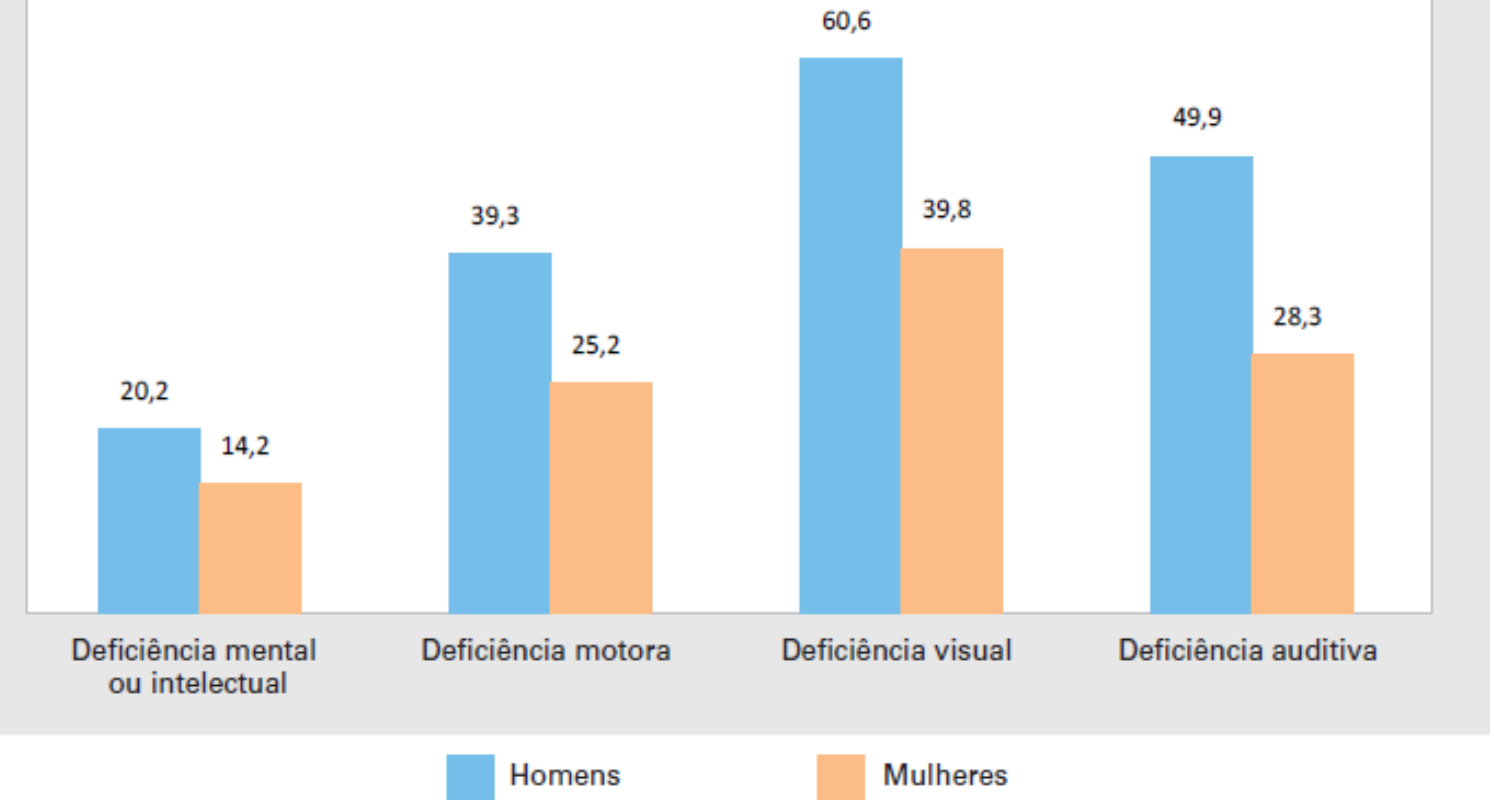

Gráfico 9 - Nível de ocupação da população de 10 anos ou mais de idade, por sexo, segundo o tipo de deficiência investigada (IBGE, Censo Demográfico 2010)

Considerando a posição na ocupação e a categoria do emprego no trabalho principal, verificou-se que a maioria das pessoas ocupadas com pelo menos uma das deficiências investigadas era empregada com carteira de trabalho assinada (40,2\%), embora em percentual menor do que as pessoas sem nenhuma deficiência $(49,2 \%)$.

Em relação ao rendimento nominal mensal de trabalho percebido pelas pessoas de 10 anos ou mais de idade ocupadas na semana de referência, com pelo menos uma das deficiências investigadas, observou-se que 46,4\% dessa população ganhava até 1 salário mínimo ou não tinha rendimento, uma diferença de mais de nove pontos percentuais para a população sem qualquer dessas deficiências $(37,1 \%)$. 


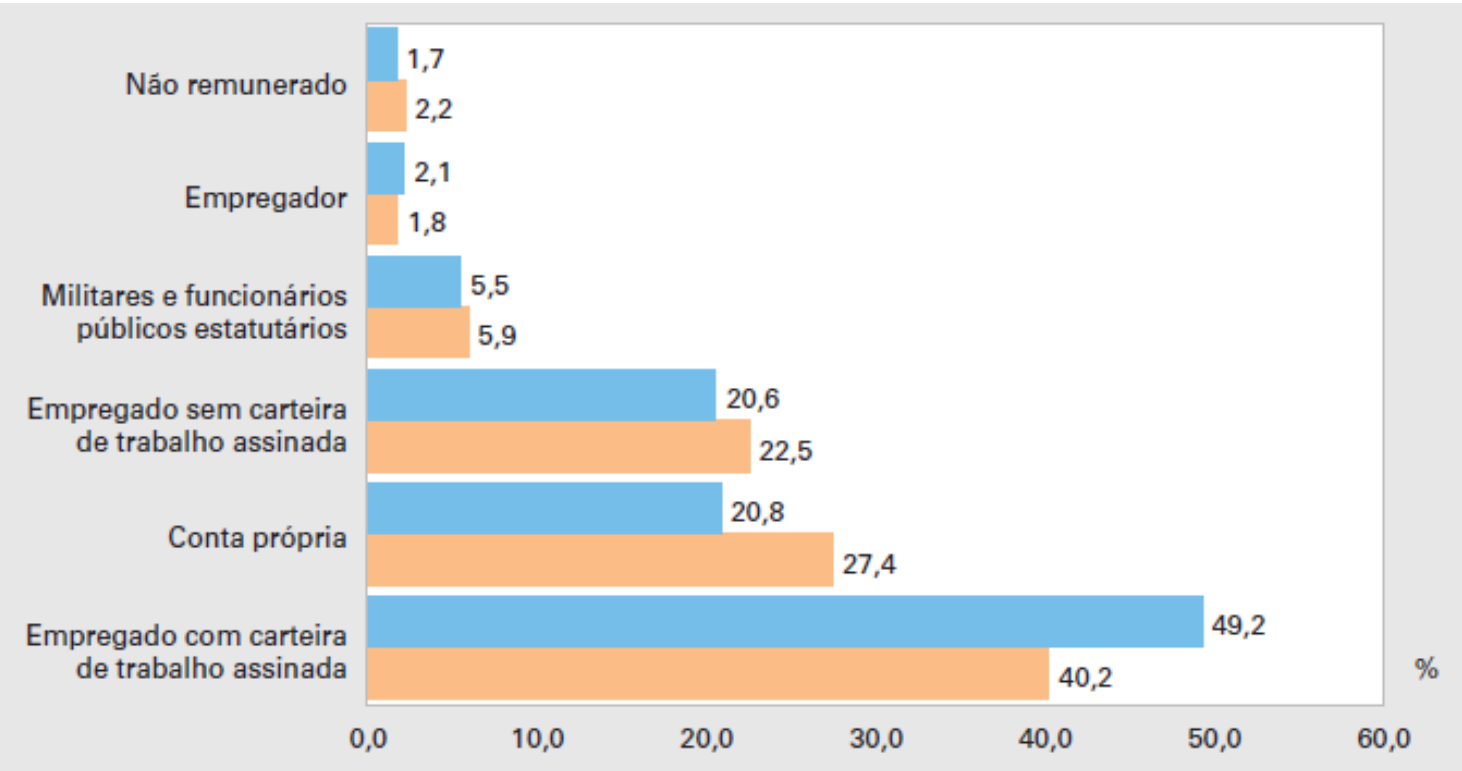

\begin{tabular}{l|l} 
Nenhuma das & $\begin{array}{l}\text { Pelo menos uma } \\
\text { das defiiências investigadas }\end{array}$
\end{tabular}

Gráfico 10 - Distribuição das pessoas de 10 anos ou mais de idade, ocupadas na semana de referência, por existência de pelo menos uma das deficiências investigadas, segundo a posição na ocupação no trabalho principal (IBGE, Censo Demográfico 2010)

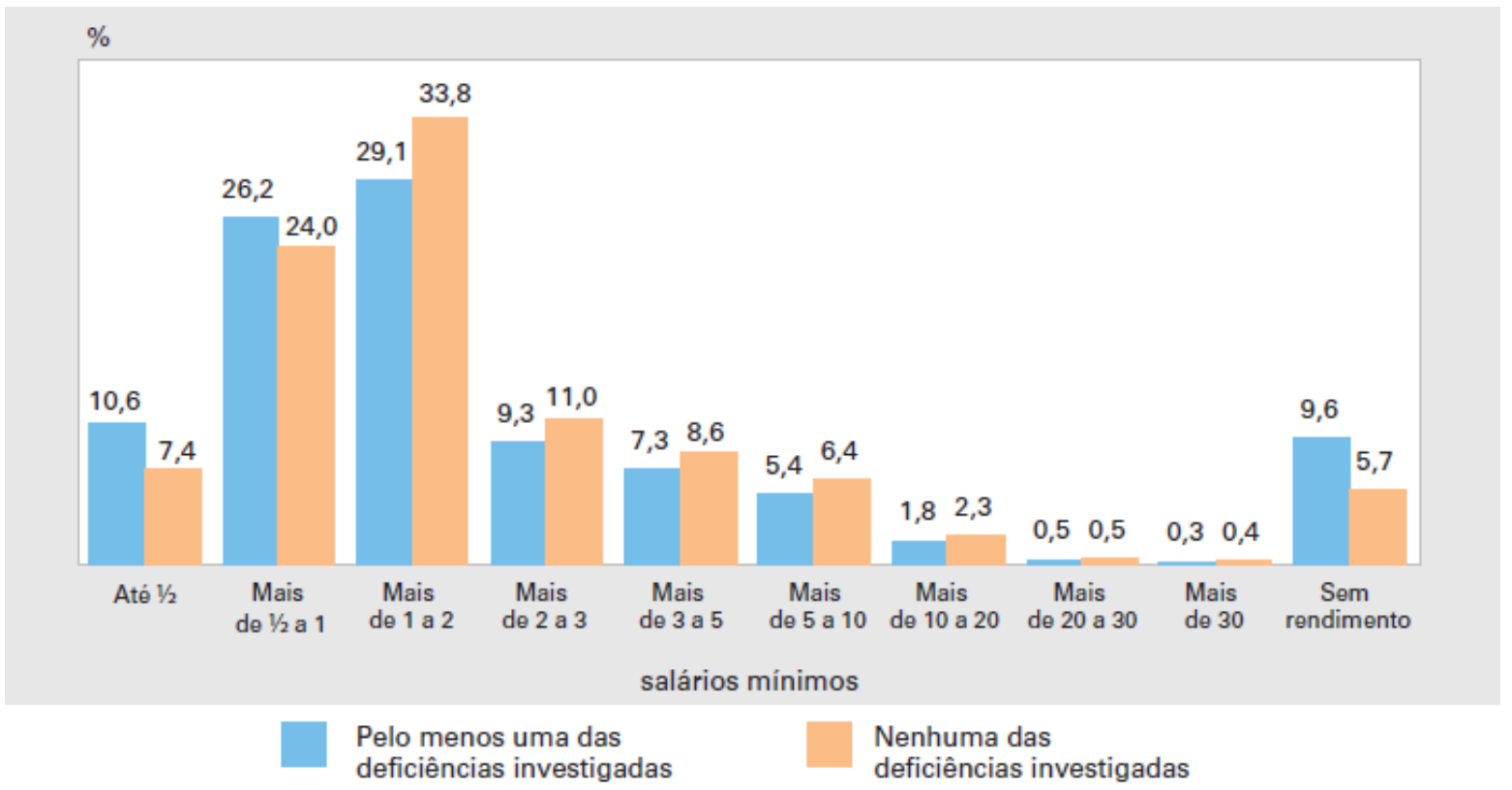

Gráfico 11 - Distribuição das pessoas de 10 anos ou mais de idade, ocupadas na semana de referência, por existência de pelo menos uma das deficiências investigadas, segundo aas classes de rendimento nominal mensal de todos os trabalhos (IBGE, Censo Demográfico 2010) 
Tabela 4 - Distribuição percentual das pessoas de 10 anos ou mais de idade, ocupadas na semana de referência, por condição de existência de deficiência, segundo as classes de rendimento nominal mensal de todos os trabalho (IBGE, Censo Demográfico 2010)

\begin{tabular}{|c|c|c|c|c|c|}
\hline \multirow{2}{*}{$\begin{array}{l}\text { Classes de rendimento } \\
\text { nominal mental de } \\
\text { todos os trabalhos } \\
\text { (salários mínimos) }\end{array}$} & \multicolumn{5}{|c|}{$\begin{array}{c}\text { Distribuiçăo percentual das pessoas de } 10 \text { anos ou mais de idade, } \\
\text { ocupadas na semana de referência, } \\
\text { por condiçăo de existência de deficiência (\%) }\end{array}$} \\
\hline & $\begin{array}{l}\text { Com } \\
\text { deficiência } \\
\text { visual }\end{array}$ & $\begin{array}{l}\text { Com } \\
\text { deficiência } \\
\text { auditiva }\end{array}$ & $\begin{array}{l}\text { Com } \\
\text { deficiência } \\
\text { motora }\end{array}$ & $\begin{array}{l}\text { Com } \\
\text { deficiência } \\
\text { mental ou } \\
\text { intelectual }\end{array}$ & $\begin{array}{l}\text { Nenhuma das } \\
\text { deficiências } \\
\text { investigadas } \\
\text { (1) }\end{array}$ \\
\hline Total & 100,0 & 100,0 & 100,0 & 100,0 & 100,0 \\
\hline Até $1 / 2$ & 10,6 & 11,3 & 14,2 & 16,7 & 7,4 \\
\hline Mais de $1 / 2$ a 1 & 26,2 & 25,7 & 28,7 & 27,6 & 24,0 \\
\hline Mais de 1 a 2 & 29,0 & 28,4 & 24,9 & 22,4 & 33,8 \\
\hline Mais de 2 a 3 & 9,4 & 9,0 & 7,1 & 5,7 & 11,0 \\
\hline Mais de 3 a 5 & 7,3 & 6,7 & 5,2 & 4,2 & 8,6 \\
\hline Mais de 5 a 10 & 5,5 & 4,7 & 3,4 & 2,8 & 6,4 \\
\hline Mais de 10 a 20 & 1,9 & 1,6 & 1,1 & 0,9 & 2,3 \\
\hline Mais de 20 a 30 & 0,5 & 0,4 & 0,3 & 0,2 & 0,5 \\
\hline Mais de 30 & 0,3 & 0,3 & 0,2 & 0,2 & 0,4 \\
\hline Sem rendimento & 9,5 & 12,0 & 14,9 & 19,4 & 5,7 \\
\hline
\end{tabular}

(1) Inclusive a populaçăo sem qualquer tipo de deficiência.

Assim sendo, com o intuito de traçar um panorama nacional, foram observados os parâmetros de concentração de pessoas deficientes por região do Brasil, a divisão por sexo (feminino e masculino), a análise por idade, cor e raça, nível de instrução e, em especial, a proporção da inserção da pessoa com deficiência no mercado de trabalho.

Diante desse cenário, importante ponderar as informações lançadas no Boletim de Indicadores do Mercado de Trabalho - Pessoas com Deficiência n. 5, elaborado pelo Ministério do Trabalho e Emprego. ${ }^{212}$

${ }^{212}$ BRASIL. Ministério do Trabalho e Emprego. Boletim de Indicadores do Mercado de Trabalho: $\begin{array}{lllll}\text { pessoas com } & \text { deficiência, } & \text { n. } & \text { Disponível }\end{array}$ <http://portal.mte.gov.br/data/files/8A7C816A3345B2BF01334675D7DF2930/indicadores_boletim_01.pdf >. Acesso em: 28 dez. 2012. 


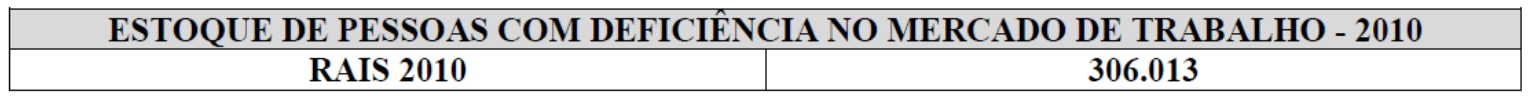

\begin{tabular}{|c|c|c|c|c|}
\hline \multirow{2}{*}{ MÊS } & \multicolumn{2}{|c|}{ ADMITIDOS } & \multicolumn{2}{c|}{ SALDO } \\
\cline { 2 - 4 } & $\mathbf{2 0 1 0}$ & $\mathbf{2 0 1 1}$ & $\mathbf{2 0 1 0}$ & $\mathbf{2 0 1 1}$ \\
\hline Maio & 7.011 & 8.148 & +854 & +931 \\
\hline Junho & 5.758 & 6.956 & +104 & +454 \\
\hline Julho & 6.118 & 7.195 & +484 & +643 \\
\hline Agosto & 6.545 & 7.474 & +727 & +351 \\
\hline $\mathbf{2}^{\mathbf{0}}$ QUADRIMESTRE & $\mathbf{2 5 . 4 3 2}$ & $\mathbf{2 9 . 7 7 3}$ & $+\mathbf{2 . 1 6 9}$ & $+\mathbf{2 . 3 7 9}$ \\
\hline $\mathbf{1}^{\mathbf{0}}$ QUADRIMESTRE & $\mathbf{2 3 . 4 4 9}$ & $\mathbf{2 5 . 7 3 0}$ & $+\mathbf{6 4 2}$ & $+\mathbf{5 3 3}$ \\
\hline TOTAL & $\mathbf{4 8 . 8 8 1}$ & $\mathbf{5 5 . 5 0 3}$ & $+\mathbf{2 . 8 1 1}$ & $+\mathbf{2 . 9 1 2}$ \\
\hline
\end{tabular}

Quadro 1 - Estoque de pessoas com deficiência no mercado de trabalho, 2010 (CAGED, $2^{\circ}$ quadrimestre de 2011)

Resta claro, diante das pesquisas realizadas pelo IBGE e pelo Ministério do Trabalho e Emprego, o considerável crescimento da inserção da pessoa com deficiência no mercado de trabalho. Referidos resultados devem-se, em especial, ao fato de que todas as regiões do Brasil promoveram inúmeras ações afirmativas a fim de implementar políticas públicas de promoção de igualdade de oportunidades no mercado de trabalho, relativas à pessoa com deficiência, bem como à constante participação e fiscalização do Ministério do Trabalho e Emprego e do Ministério Público do Trabalho. 


\section{CONCLUSÃO}

A intenção apontada pela Constituição Federal de 1988 é a de alcançar uma sociedade livre, justa e solidária. Contudo, é inconteste a importância da igualdade de oportunidades, a qual somente será alcançada através do acesso à educação, à saúde e ao trabalho.

O valor atribuído ao trabalho constitui postulado básico da dignidade humana, sendo o trabalho reconhecido como um direito universal que deve ser assegurado a todos, sem exceção.

Portanto, inicialmente deve ser afastado o sentimento de piedade e a ideia errônea de que a pessoa deficiente é incapaz para o trabalho. Ofertada a oportunidade de emprego à pessoa com deficiência, esta vislumbrará uma real possibilidade de participação na vida socioeconômica.

Desta feita, antes de excluir suas possibilidades de desenvolvimento ou de afirmar que uma pessoa com deficiência não possui habilidades para trabalhar em determinada função, é necessário fornecer a oportunidade para que possa desempenhar suas reais habilidades, devendo ser observada inclusive a adaptação dos postos de trabalho.

Nota-se, ainda, que a inclusão da pessoa com deficiência no mercado de trabalho formal resulta na importante incorporação de sua renda na economia, sendo certo que desonera o Estado dos encargos previdenciários e assistenciais a ela relacionadas.

Diante dos resultados expressivos apontados pelo Censo Demográfico 2010 realizado pelo IBGE - 23,9\% da população brasileira possui algum tipo de deficiência, cerca de 45 milhões de pessoas ${ }^{213}$ —, cumpre mencionar que o presente trabalho buscou analisar de forma criteriosa a inclusão da pessoa com deficiência no mercado de trabalho.

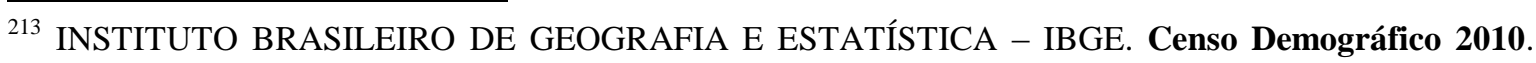
Disponível em: 〈http://censo2010.ibge.gov.br/resultados〉. Acesso em: 18 out. 2012. 
Como visto ao longo do presente estudo, o Brasil conta com inúmeras leis regulamentadoras no tocante à pessoa com deficiência. Assim, cumpre ao Estado e à sociedade envidar esforços para o cumprimento da legislação devidamente regulamentada.

Nesse descortino, buscou-se discorrer sobre a evolução do ordenamento jurídico brasileiro diante do tema em tela, ponderando a aplicação objetiva da Carta Magna e da Lei que dispõe sobre os benefícios da Previdência Social e sobre a inserção do sistema de reserva de vagas do setor privado (Lei n. 8.213/91), sobre o papel, como órgãos fiscalizadores, do Ministério Público do Trabalho (MPT) e do Ministério do Trabalho e Emprego (MTE) e, ainda, sobre quais seriam os mecanismos e incentivos de cumprimento da legislação.

De fato, não se pretende afastar os inúmeros óbices para o cumprimento da Lei n. 8.212/91, seja a baixa qualificação das pessoas com deficiências ou o alto custo para a inserção desta categoria de pessoas, mas o disposto no artigo 93 da mencionada Lei gerou o aumento de vagas e contratos de trabalhos firmados com pessoas deficientes nos mais diversos ramos empresariais e nas mais diversas funções.

Conclui-se que a implementação do sistema legal de reserva de vagas com intuito de obrigar as empresas a contratarem pessoas com deficiência está em consonância com as normas internacionais e com os dispositivos constitucionais. No entanto, somente a observância do referido sistema não é capaz de resolver a questão da exclusão da pessoa deficiente do mercado de trabalho, a qual certamente decorre de um processo histórico de marginalização e exclusão em todas as esferas.

A inclusão social e laboral da pessoa deficiente é uma tarefa complexa e árdua de ser concretizada, sendo certo que envolve inúmeros fatores, como educação, qualificação, eliminação de barreiras arquitetônicas e adequação do meio ambiente de trabalho.

No atual momento, o que se deve ponderar é a importância do sistema em vigor, que deve ser mantido, e levantar quais seriam as ações afirmativas necessárias e que poderão futuramente ser implementadas, tais como: a) a concessão de incentivos financeiros às empresas, através de subsídios para a adaptação da estrutura arquitetônica da 
empresa ou através da redução das contribuições previdenciárias patronais com intuito de estimular a contratação; b) a obrigatoriedade no tocante ao efetivo preenchimento da legislação como pré-requisito indispensável para a participação em licitações, concorrências públicas e pedidos de empréstimos pelo Banco Nacional de desenvolvimento Econômico e Social - BNDES; e c) implementação de programas de governo nas áreas de educação, saúde e acessibilidade.

Em paralelo à realização de ações afirmativas, merece ser levantado o tema da inclusão de pessoas ou "padrões" não contemplados na Lei n. 8.213/91 e no Decreto n. 3.298/99 para fins do preenchimento da reserva legal, bem como ser observada a interpretação ampla da legislação vigente.

Conforme amplamente debatido no presente trabalho, as pessoas queimadas, com surdez unilateral, lábio leporino e/ou fenda palatina, diabéticas insulino-dependentes, excancerosas e obesas formam um grupo de pessoas com características específicas, sendo certo que o disposto na Lei n. 3.298/99 não prevê a inclusão desse tipo de "deficiência invisível".

A exclusão do mercado de trabalho desta parcela da população é notória, bem como as inúmeras dificuldades encontradas quando da realização de um processo seletivo.

Para este fim, é necessária, além de uma alteração legislativa, uma significativa alteração cultural, devendo ser compreendido o real sentido da expressão "inclusão" através da atividade profissional, porquanto esta eleva o respeito aos direitos e garantias do indivíduo e afasta qualquer imposição de condição, possibilidade ou padrão. 


\section{REFERÊNCIAS}

AIDAR, Carlos Miguel C. Perspectiva didática dos tratados internacionais. In: AMARAL, Antonio Carlos Rodrigues do (Coord.). Tratados internacionais na ordem jurídica brasileira. São Paulo: Lex; Aduaneiras, 2005.

ALVES, Rubens Valtecides. Deficiente físico: novas dimensões da proteção ao trabalhador. São Paulo: LTr, 1992.

ANDRADE, Denise Lapolla de Paula Aguiar. Portadores de deficiência: sujeitos de direitos. Revista do Ministério Público do Trabalho. Brasília: LTr, v. 10, n. 19, p. 55-62, mar. 2000.

ARAÚJO, Luiz Alberto David. A proteção constitucional das pessoas portadoras de deficiência. 2. ed. Brasília: Corde, 1996.

ASSIS, Olney Queiroz; PUSSOLI, Lafaiete. Pessoa deficiente: direitos e garantias. São Paulo: Edipro, 1992.

BATISTA, Cristina Abranches Mota. A inclusão no trabalho. In: BATISTA, Cristina Abranches Mota et al. (Org.). Inclusão dá trabalho. Belo Horizonte: Armazém de Idéias, 2000 .

BELTRAN, Ari Possidonio. Dilemas do trabalho e do emprego na atualidade. São Paulo: LTr, 2001.

BELTRAN, Ari Possidonio. Direito do trabalho e direitos fundamentais. São Paulo: LTr, 2002.

BELTRAN, Ari Possidonio. Os impactos da integração econômica no direito do trabalho: globalização e direitos sociais. São Paulo: LTr, 1998.

BENJAMIN, Antonio Herman de Vasconcelos e. A tutela das pessoas portadoras de deficiência pelo Ministério Público. Direitos da pessoa portadora de deficiência. Revista da Advocacia Pública \& Sociedade. São Paulo, ano 1, n. 1, p. 13-38, 1997.

BERTOLIN, Patrícia Tuma Martins. A discriminação às pessoas com deficiência nas relações de trabalho. Revista de Direito do Trabalho. São Paulo, ano 32, n. 123, p. 183 201, jul./set. 2006. 
BERVENVANÇO, Rosana Beraldi. Direitos da pessoa portadora de deficiência: da exclusão à igualdade. Curitiba: Ministério Público do Estado do Paraná, 2001.

BOLONHINI JUNIOR, Roberto. Portadores de necessidades especiais: as principais prerrogativas dos portadores de necessidades especiais e a legislação brasileira. São Paulo: Arx, 2004.

BOUCINHAS FILHO, Jorge Cavalcanti. Ações afirmativas e inserção de pessoas portadoras de deficiência no mercado de trabalho. Revista da Faculdade de Direito Universidade de São Paulo. São Paulo, v. 100, p. 493-523, jan./dez. 2005.

BRASIL. Constituição da República Federativa do Brasil de 1988. Disponível em: <http://www.planalto.gov.br/ccivil_03/constituicao/ConstituicaoCompilado.htm>. Acesso em: $11 \mathrm{dez} .2012$.

BRASIL. Decreto n. 3.298, de 20 de dezembro de 1999. Disponível em: <http://www.planalto.gov.br/ccivil_03/decreto/d3298.htm>. Acesso em: 18 dez. 2012.

BRASIL. Decreto n. 3.956, de 8 de outubro de 2001. Disponível em: <http://www.planalto.gov.br/ccivil_03/decreto/2001/d3956.htm>. Acesso em: 10 jul. 2011.

BRASIL. Decreto n. 6.949, de 25 de agosto de 2009. Disponível em: <http://www.planalto.gov.br/ccivil_03/_ato2007-2010/2009/decreto/d6949.htm>. Acesso em: 25 jun. 2011.

BRASIL. Decreto-Lei n. 5.452, de $\mathbf{1}^{\mathbf{0}}$ de maio de 1943. Disponível em: <http://www.planalto.gov.br/ccivil_03/decreto-lei/Del5452compilado.htm>. Acesso em: 23 dez. 2012.

BRASIL. Emenda Constitucional n. 1, de 17 de outubro de 1969. Disponível em: $<$ http://www.planalto.gov.br/ccivil_03/constituicao/Emendas/Emc_anterior1988/emc0169.htm>. Acesso em: $11 \mathrm{dez} .2012$.

BRASIL. Emenda Constitucional n. 12, de 17 de outubro de 1978. Disponível em: <https://www.planalto.gov.br/ccivil_03/constituicao/emendas/emc_anterior1988/emc1278.htm>. Acesso em: $11 \mathrm{dez} .2012$.

BRASIL. Lei Complementar n. 75, 20 de maio de 1993. Disponível em: <http://www.planalto.gov.br/ccivil_03/leis/lcp/lcp75.htm>. Acesso em: 18 dez. 2012. 
BRASIL. Lei n. 7.102, de 20 de junho de 1983. Disponível em: <http:// www.planalto.gov.br/ccivil_03/leis/L7102compilado.htm>. Acesso em: 17 dez. 2012.

BRASIL. Lei n. 7.853, de 24 de outubro de 1989. Disponível em: <http:// www.planalto.gov.br/ccivil_03/leis/L7853compilado.htm>. Acesso em: 22 dez. 2012.

BRASIL. Lei n. 8.112, de 11 de dezembro de 1990. Disponível em: <http:// www.planalto.gov.br/ccivil_03/leis/L8112compilado.htm>. Acesso em: 12 dez. 2012.

BRASIL. Lei n. 8.213, de 24 de julho de 1991. Disponível em: <http:// www.planalto.gov.br/ccivil_03/leis/L8213compilado.htm>. Acesso em: 13 dez. 2012.

BRASIL. Ministério da Previdência Social; Ministério da Fazenda. Portaria Interministerial MPS/MF n. 02, de 06 de janeiro de 2012. Disponível em: <http://www010.dataprev.gov.br/sislex/paginas/65/mf-mps/2012/2.htm>. Acesso em: 18 dez. 2012.

BRASIL. Ministério do Trabalho e Emprego. A inclusão das pessoas com deficiência no mercado de trabalho. Brasília, 2007. Disponível em: <http:// www.acessibilidade.org.br/cartilha_trabalho.pdf>. Acesso em 13 jan. 2013.

BRASIL. Ministério do Trabalho e Emprego. Boletim de Indicadores do Mercado de Trabalho: pessoas com deficiência, n. 05. Disponível em: <http:// portal.mte.gov.br/data/files/8A7C816A3345B2BF01334675D7DF2930/indicadores_boleti m_01.pdf>. Acesso em: $28 \mathrm{dez} .2012$.

BRASIL. Ministério do Trabalho e Emprego. Instrução Normativa n. 20, de 26 de janeiro de 2001. Disponível em: <http://portal.mte.gov.br/legislacao/instrucao-normativan-20-de-26-01-2001.htm>. Acesso em: 18 dez. 2012.

BRASIL. Ministério do Trabalho e Emprego. NR n. 4: serviços especializados em engenharia de segurança e em medicina do trabalho. Disponível em: <http://portal.mte.gov.br/data/files/8a7c812d36a2800001388128376306ad/nr-

04\%20(atualizada).pdf>. Acesso em: 17 dez. 2012.

BRASIL. Ministério do Trabalho e Emprego. Portaria n. 1.199, de 28 de outubro de 2003. Disponível em: <http://portal.mte.gov.br/legislacao/portaria-n-1-199-de-28-102003.htm>. Acesso em: 18 dez. 2012.

CAMARgos, Ana Amélia Mascarenhas. Direito do Trabalho no terceiro setor. São Paulo: Saraiva, 2007. 
CARRION, Valentin. Comentários à Consolidação das Leis do Trabalho. 34. ed. atual. São Paulo: Saraiva, 2009.

CASTRO, Carlos Roberto Siqueira. A Constituição aberta e os direitos fundamentais. Rio de Janeiro: Forense, 2005.

CAVALCANTE, Jouberto de Quadros Pessoa; JORGE NETO, Francisco Ferreira. O conteúdo jurídico da proteção ao portador de deficiência física prevista no artigo 93 da lei n. 8.213/91. Revista Magister de Direito Trabalhista e Previdenciário. Porto Alegre, ano 2 , n. 9, p. 50-55, nov./dez. 2005.

CAVALCANTE, Jouberto de Quadros Pessoa; JORGE NETO, Francisco Ferreira. O portador de deficiência no mercado de trabalho. LTr Suplemento Trabalhista. São Paulo: LTr, v. 37, n. 168, p. 811-818, 2001.

CIDADE, Ruth Eugênia Amarante; FREITAS, Patrícia Silvestre de. Introdução à educação física e ao desporto para pessoas portadoras de deficiência. Curitiba: UFPR, 2002.

COMPARATO, Fábio Konder. A afirmação histórica dos direitos humanos. 3. ed. São Paulo: Saraiva, 2004.

COMPARATO, Fábio Konder. Igualdade, desigualdades. Revista Trimestral de Direito Público. São Paulo, v. 1, 1993.

COSTA, Sandra Morais de Brito. Dignidade humana e pessoa com deficiência: aspectos legais e trabalhistas. São Paul: LTr, 2008.

CURY, Munir; AMARAL E SILVA, Antônio Fernando; MENDEZ, Emílio García (Coord.). Estatuto da criança e do adolescente comentado: comentários jurídicos e sociais. 4. ed. São Paulo: Malheiros, 2002.

DAMASCENO, Fernando Américo Veiga. Equiparação salarial. 2. ed. São Paulo: LTr, 1995.

DELGADO, Mauricio Godinho. Curso de Direito do Trabalho. São Paulo: LTr, 2005.

DICKSON, Mary B. The americans with disabilities act: hiring, accommodating and supervising employees with disabilities. [S.I.]: Crisp Publications, 1995. 
ESPANHA. Constitución Española. Disponível em: <http://www.boe.es/boe/dias/1978/12/29/pdfs/A29313-29424.pdf>. Acesso em: 6 dez. 2012.

ESPANHA. Ley de Integración Social de los Minusválidos. Disponível em: <http://www.feaps.org/archivo/centro-documental/doc_download/330-lismi-ley-131982de-integracion-social-de-los-minusvalidos.html>. Acesso em: 6 dez. 2012.

FÁVERO, Eugênia Augusta Gonzaga. Direitos das pessoas com deficiência: garantia de igualdade na diversidade. Rio de Janeiro: WVA, 2004.

FERREIRA FILHO, Manoel Antonio. Comentários à Constituição Brasileira: Emenda Constitucional n. 1, de 17-10-1969, com as alterações introduzidas pelas Emendas Constitucionais até a de n. 27, de 27-11-1985. 6. ed. São Paulo: Saraiva, 1986.

FIGUEIREDO, Guilherme José Purvin de. A pessoa portadora de deficiência física e o princípio da igualdade de oportunidades no direito do trabalho. In: Direitos da pessoa portadora de deficiência. Coleção Advocacia Pública \& Sociedade, n. 1, São Paulo: IBAP - Instituto Brasileiro de Advocacia Pública; Max Limonad, 1997.

FONSECA, Ricardo Tadeu Marques da. A ONU e o seu conceito revolucionário de pessoa com deficiência. Revista Legislação do Trabalho. São Paulo: LTr, v. 72, n. 3, p. 263-270, mar. 2008.

FONSECA, Ricardo Tadeu Marques da. O trabalho da pessoa com deficiência e a lapidação dos direitos humanos: o direito do trabalho, uma ação afirmativa. São Paulo: LTr, 2006.

FRANCIS, Leslie Pickering; SILVERS, Anita. Americans with disabilities: exploring implications of the law for individuals and institutions. New York: Routledge, 2000.

FUNDAÇÃO DE ARTICULAÇÃO E DESENVOLVIMENTO DE POLÍTICAS PÚBLICAS PARA PCD E PCAH NO RIO GRANDE DO SUL - FADERS. Cartilha Atitudes que fazem a diferença com PCD. Disponível em: <http://www.faders.rs.gov.br/portal/index.php?id=ligislacao\&cat=6>. Acesso em: 17 nov. 2012.

GABRILLI, Mara. Quem é deficiente: a cidade ou as pessoas que têm uma limitação física ou sensorial? Revista do Advogado. São Paulo, n. 95, p. 92-97, dez. 2007.

GIL, Marta (Coord.). O que as empresas podem fazer pela inclusão das pessoas com deficiência. São Paulo: Instituto Ethos, 2002. 
GIORDANO, Blanche Wazée. (D)eficiência e trabalho: analisando suas representações. São Paulo: Fapesp, 2000.

GOLDFARB, Cibelle Linero. Pessoas portadoras de deficiência e a relação de emprego: o sistema de cotas no Brasil. Curitiba: Juruá, 2008.

GOMES, Joaquim B. Barbosa. Ação afirmativa e princípio constitucional da igualdade: o direito como instrumento de transformação social: a experiência dos EUA. Rio de Janeiro: Renovar, 2001.

GUGEL, Maria Aparecida. O trabalho do portador de deficiência: comentários ao decreto n. 3.298/99. Gênesis - Revista de Direito do Trabalho. Curitiba: Gênesis, v. 15, n. 88, p. 564-572, abr. 2000.

GUGEL, Maria Aparecida. Pessoas com deficiência e o direito ao concurso público. Goiânia: UCG, 2006.

INSTITUTO BRASILEIRO DE GEOGRAFIA E ESTATÍSTICA - IBGE. Censo Demográfico 2000. Disponível em: <http://www.ibge.gov.br/home/presidencia/noticias/20122002censo.shtm>. Acesso em: 01 jun. 2011.

INSTITUTO BRASILEIRO DE GEOGRAFIA E ESTATÍSTICA - IBGE. Censo Demográfico 2010. Disponível em: <ftp://ftp.ibge.gov.br/Censos/Censo_Demografico_ 2010/Trabalho_e_Rendimento/censo_trabalho_e_rendimento.pdf>. Acesso em: 27 dez. 2012.

INSTITUTO BRASILEIRO DE GEOGRAFIA E ESTATÍSTICA- IBGE. Censo Demográfico 2010: trabalho e rendimento: resultados da amostra. Disponível em: <http://censo2010.ibge.gov.br/resultados>. Acesso em: 19 dez. 2012.

INSTITUTO BRASILEIRO DE GEOGRAFIA E ESTATÍSTICA- IBGE. Censo Demográfico 2010: resultados gerais da amostra: características gerais da população, religião e pessoas com deficiência. Disponível em: <http://censo2010.ibge.gov.br/ resultados>. Acesso em: 29 jun. 2012.

INSTITUTO BRASILEIRO DE GEOGRAFIA E ESTATÍSTICA- IBGE. Censo Demográfico 2010: primeiros resultados. Disponível em: <http:// censo2010.ibge.gov.br/resultados>. Acesso em: 29 nov. 2010.

ITÁLIA. La Costituzione. Disponível em: <http://www.quirinale.it/qrnw/statico/ costituzione/costituzione.htm>. Acesso em: 10 dez. 2012. 
KALUME, Pedro de Alcântara. Deficientes: ainda um desafio para o governo e para a sociedade: LTr, 2006.

LANTAS, Jaime José Bilek. O Ministério Público do Trabalho e a proteção de interesses do trabalhador portador de deficiência. Revista do Ministério Público do Trabalho. Brasília: LTr, v. 9, n. 17, p. 68-72, mar. 1999.

LEITE, Carlos Henrique Bezerra. Constituição de direitos sociais dos trabalhadores. São Paulo: LTr, 1997.

LEITE, Carlos Henrique Bezerra. Curso de direito processual do trabalho. 5. ed. São Paulo: LTr, 2007.

LEITE, Carlos Henrique Bezerra. Ministério Público do Trabalho. São Paulo: LTr, 2006.

LOPES, Cristiane Maria Sbalqueiro. Aplicação da legislação de reserva de vagas em concursos públicos como concretização político-jurídica do princípio da igualdade. Revista do Ministério Público do Trabalho. Brasília, ano 13, n. 25, mar. 2003.

LOPES, Glaucia Gomes Vergara. A inserção do portador de deficiência no mercado de trabalho: a efetividade das leis brasileiras. São Paulo: LTr, 2005.

LORENTZ, Lutiana Nacur. A norma da igualdade e o trabalho das pessoas portadoras de deficiência. São Paulo, LTr, 2006.

LORENTZ, Lutiana Nacur. A proteção da lei aos portadores de deficiência no mercado de trabalho. Revista do Ministério Público do Trabalho. Brasília, ano 9, n. 17, p. 56-67, mar. 1999.

MAGAnO, Octavio Bueno. Manual de Direito do Trabalho, 3. ed. rev. e atual. São Paulo: LTr, 1992.

MAIOR, Jorge Luiz Souto. O Direito do Trabalho como instrumento de justiça social. São Paulo: LTr, 2000.

MALTA, Christovão Piragibe Tostes. Prática do processo trabalhista. 32. ed, São Paulo: LTr, 2004. 
MANDALOZZO, Silvana Souza Netto; COSTA, Lucia Cortes da. Algumas categorias não protegidas plenamente pelo Direito do Trabalho: portadores de deficiência, idosos e acometidos de doenças graves. Revista Legislação do Trabalho. São Paulo: LTr, v. 71, n. 5, p. 598-603, maio 2007.

MANUS, Pedro Paulo Teixeira. Despedida arbitrária ou sem justa causa. São Paulo: Malheiros, 1996.

MARANHÃO, Rosanne de Oliveira. O portador de deficiência e o Direito do Trabalho. São Paulo: LTr, 2005.

MARCHI, Eduardo C. Silveira. Guia de metodologia jurídica: teses, monografias e artigos. 2. ed. São Paulo: Saraiva, 2009.

MARQUES, Christiani. O contrato de trabalho e a discriminação estética. São Paulo: LTr, 2002.

MARTINS, Sérgio Pinto. Direito da seguridade social. 19. ed., São Paulo: Atlas, 2003.

MARTINS, Sérgio Pinto. Direito do Trabalho. 22. ed., São Paulo: Atlas, 2006.

MARTINS, Sérgio Pinto. Direito Processual do Trabalho: doutrina e prática forense. 25. ed., São Paulo: Atlas, 2006.

MAZZILLI, Hugo Nigro. A pessoa portadora de deficiência e o mercado de trabalho. Revista de Direito do Trabalho. São Paulo: Revista dos Tribunais, ano 27, n. 101, p. 203 205, jan./mar. 2001.

MAZZILLI, Hugo Nigro. A pessoa portadora de deficiência e o Ministério Público: direitos da pessoa portadora de deficiência. Revista da Advocacia Pública \& Sociedade. São Paulo, ano 1, n. 1, p. 77-95, 1997.

MEDEIROS, Adriane de Araujo. Direito da pessoa portadora de deficiência ao trabalho e o papel do Ministério Público do Trabalho. Revista do Ministério Público do Trabalho. Brasília: LTr, ano 8, n. 15, p. 45-52, mar./1998.

MELLO, Celso Antonio Bandeira de. Conteúdo jurídico do princípio da igualdade. 4. ed., São Paulo: Malheiros, 2006. 
MELLO, Celso de Albuquerque. O princípio da igualdade no Direito Internacional Público. Revista da Ordem dos Advogados do Brasil. Rio de Janeiro, v. 20, n. 15, 1981.

MELO, Sandro Nahmias. O direito ao trabalho da pessoa portadora de deficiência: ação afirmativa, o princípio constitucional da igualdade. São Paulo: LTr, 2004.

MIRANDA, Pontes de. Comentários à Constituição de 1967: com a Emenda n. 1, de 1969. 2. ed., São Paulo: Revista dos Tribunais, 1972.

NASCIMENTO, Amauri Mascaro. Curso de Direito do Trabalho. 21. ed., São Paulo: Saraiva, 2006.

NIESS, Luciana Toledo Távora; NIESS, Pedro Henrique Távora. Pessoas portadoras de deficiência no Direito brasileiro. São Paulo: Juarez de Oliveira, 2003.

OLIVEIRA, Francisco Antonio. Do concurso a magistratura e a reserva de vagas para deficientes. Revista LTr. São Paulo, v. 67, n. 2, fev. 2003.

OLIVEIRA, Paulo Eduardo Vieira de. O dano pessoal no Direito do Trabalho. São Paulo: LTr, 2002.

ORGANIZAÇÃO DAS NAÇÕES UNIDAS - ONU. Conheça a ONU. Disponível em: <http://onu.org.br/conheca-a-onu>. Acesso em: 16 nov. 2012.

ORGANIZAÇÃO DAS NAÇÕES UNIDAS - ONU. Declaração de Salamanca sobre princípios, políticas e práticas na área das necessidades educativas especiais. Disponível em: <http://portal.mec.gov.br/seesp/arquivos/pdf/salamanca.pdf>. Acesso em: 17 nov. 2012.

ORGANIZAÇÃO DAS NAÇÕES UNIDAS - ONU. Declaração dos Direitos das Pessoas Portadoras de Deficiência. Disponível em: <http:// www.mte.gov.br/fisca_trab/inclusao/legislacao_2_4.asp>. Acesso em: 16 nov. 2012.

ORGANIZAÇÃO DAS NAÇÕES UNIDAS - ONU. Declaração Universal dos Direitos Humanos. Disponível em: <http://unicrio.org.br/img/DeclU_D_HumanosVerso Internet.pdf>. Acesso em: 16 nov. 2012.

ORGANIZAÇÃO DAS NAÇÕES UNIDAS - ONU. Mais de um bilhão de pessoas no mundo têm algum tipo de deficiência, informa relatório da ONU. Disponível em: $<$ http://onu.org.br/mais-de-um-bilhao-de-pessoas-no-mundo-tem-algum-tipo-dedeficiencia-informa-relatorio-da-onu>. Acesso em: 18 out. 2012. 
ORGANIZAÇÃO DOS ESTADOS AMERICANOS - OEA. Nosso propósito. Disponível em: <http://www.oas.org/pt/sobre/proposito.asp>. Acesso em: 4 dez. 2012.

ORGANIZAÇÃO DOS ESTADOS AMERICANOS - OEA. Quem somos. Disponível em: <http://www.oas.org/pt/sobre/quem_somos.asp>. Acesso em: 4 dez. 2012.

ORGANIZAÇÃO INTERNACIONAL DO TRABALHO - OIT. Apresentação. Disponível em: <http://www.oit.org.br/content/apresenta\%C3\%A7\%C3\%A3o>. Acesso em: 20 nov. 2012.

ORGANIZAÇÃO INTERNACIONAL DO TRABALHO - OIT. Conferência Internacional do Trabalho - Convenção n. 159. Disponível em: <http:// www.mte.gov.br/fisca_trab/inclusao/legislacao_2_1.asp>. Acesso em: 10 jul. 2011.

ORGANIZAÇÃO INTERNACIONAL DO TRABALHO - OIT. Discriminação em matéria de emprego e ocupação. Disponível em: 〈http://www.oit.org.br/node/472>. Acesso em: 17 nov. 2012.

ORGANIZAÇÃO INTERNACIONAL DO TRABALHO - OIT. História. Disponível em: <http://www.oit.org.br/content/hist\%C3\%B3ria>. Acesso em: 17 nov. 2012.

ORGANIZAÇÃO INTERNACIONAL DO TRABALHO - OIT. Reabilitação profissional e emprego de pessoas deficientes. Disponível em: <http:// www.oit.org.br/node/505>. Acesso em: 18 nov. 2012.

PASTORE, José. Oportunidades de trabalho para portadores de deficiência. São Paulo: LTr, 2001.

PEREIRA, Ruy Antonio de Arruda. Dos direitos trabalhistas da pessoa portadora de deficiência. Revista de Direito do Trabalho. São Paulo: Revista dos Tribunais, ano 27, n. 104, p. 228-234, out./dez. 2001.

PERU. Constitución Política del Perú. Disponível em: <http://www.tc.gob.pe/ legconperu/constitucion.html>. Acesso em: 10 dez. 2012.

PINTO, Luís Otávio Camargo. O sistema de reserva legal de vagas e a inclusão no mercado de trabalho das pessoas com deficiência mental. Revista Magister de Direito Trabalhista e Previdenciário. Porto Alegre, ano 3, n. 14, p. 22-38, set./out. 2006. 
PIOVESAN, Flávia. A Constituição brasileira de 1988 e os tratados internacionais de proteção dos direitos humanos. In: PIOVESAN, Flávia. Temas de Direitos Humanos. 2. ed., São Paulo: Max Limonad, 2003.

PIOVESAN, Flávia. Temas de Direitos Humanos. 2. ed., São Paulo: Max Limonad, 2003.

PORTUGAL. Bases gerais do regime jurídico da prevenção, habilitação, reabilitação e participação da pessoa com deficiência: Lei n. 38/2004, de 18 de agosto. Disponível em: <http://www.idesporto.pt/data/docs/legislacao/doc05_052.pdf>. Acesso em: 7 dez. 2012.

PORTUGAL. Constituição da República Portuguesa, de 2 de abril de 1976. Disponível em: <http://www.tribunalconstitucional.pt/tc/crp.html>. Acesso em: 7 dez. 2012.

PORTUGAL. Decreto-Lei n. 29/2001 de 3 de fevereiro. Disponível em: <http://www.dgap.gov.pt/upload/Legis/2001_dl_29_03_02.pdf>. Acesso em: 7 dez. 2012.

RIBAS, João B. Cintra. O que são pessoas deficientes. 6. ed., São Paulo: Brasiliense, 2003.

RIBEIRO, Lauro Luiz Gomes. Manual de direitos da pessoa com deficiência. São Paulo: Verbatim, 2010.

RIZZATTO NUNES, Luiz Antônio. O princípio constitucional da dignidade da pessoa humana. São Paulo: Saraiva, 2002.

ROCHA, Carmen Lúcia Antunes. Ação afirmativa: o conteúdo democrático do princípio da igualdade jurídica. Revista de Informação Legislativa. Brasília, ano 33, n. 131, jul./set. 1996.

RULLI NETO, Antonio. Direitos do portador de necessidades especiais: guia para o portador de deficiência e para o profissional do Direito. 2. ed., São Paulo: Fiúza Editores, 2002.

SÃO PAUlO (Estado). Lei n. 14.481, de 13 de julho de 2011. Disponível em: <http://www.al.sp.gov.br/repositorio/legislacao/lei/2011/lei\%20n.14.481,\%20de\%2013.07. 2011.htm>. Acesso em: 17 dez. 2012.

SASSAKI, Romeu Kazumi. Terminologia: sobre a deficiência na era da inclusão. Disponível em: <http://www.pessoacomdeficiencia.sp.gov.br/portal.php/informacoes/ terminologia>. Acesso em: 18 jun. 2011. 
SEVERINO, Antonio Joaquim. Metodologia do trabalho científico. 23. ed., São Paulo: Cortez, 2009.

SILVA NETO, Manoel Jorge e. Proteção constitucional dos interesses trabalhistas difusos, coletivos e individuais homogêneos. São Paulo, LTr, 2001.

SILVA, Cristiane Ribeiro da Silva. O direito ao trabalho da pessoa portadora de deficiência e os efeitos da interdição. Revista Legislação do Trabalho. São Paulo: LTr, v. 71, n. 10, p. 1228-1234, out. 2007.

SILVA, Eduardo Jannone da. Tutela jurídica do direito à saúde da pessoa portadora de deficiência. Curitiba, Juruá, 2009.

SILVA, Fernanda Duarte Lopes Lucas da. Princípio constitucional da igualdade. Rio de Janeiro: Editora Lumen Juris, 2001.

SILVA, Otto Marques da. A epopéia ignorada: a pessoa deficiente na história do mundo de ontem e de hoje. São Paulo: Cedas, 1987.

SILVA, Walküre Lopes Ribeiro da. Seguridade social e a pessoa portadora de deficiência: direitos da pessoa portadora de deficiência. Revista da Advocacia Pública \& Sociedade. São Paulo, ano 1, n. 1, 1997.

SOWELL, Thomas. Affirmative action around the world: an empirical study. New Haven: Yale University Press, 2004.

SÜSSEKIND, Arnaldo Lopes. Direito Constitucional do Trabalho. Rio de Janeiro: Renovar, 1999.

TEPERINO, Maria Paula (Coord.). Comentários à legislação federal aplicável às pessoas portadoras de deficiência. São Paulo: Forense, 2001.

UNIÃO EUROPEIA. Carta Comunitária dos Direitos Sociais Fundamentais dos Trabalhadores. Disponível em: <http://ftp.infoeuropa.eurocid.pt/database/000043001000044000/000043646.pdf>. Acesso em: 5 dez. 2012.

UNIÃO EUROPEIA. Carta dos Direitos Fundamentais. Disponível em: $<$ http://europa.eu/legislation_summaries/justice_freedom_security/combating_discriminati on/133501_pt.htm>. Acesso em: 5 dez. 2012. 
UNIÃO EUROPEIA. Council Directive 2000/43/EC of 29 June 2000, implementing the principle of equal treatment between persons irrespective of racial or ethnic origin. Disponível em: <http://eur-lex.europa.eu/LexUriServ/LexUriServ.do?uri=OJ:L:2000:180: 0022:0026:en:PDF>. Acesso em: 5 dez. 2012.

UNIÃO EUROPEIA. Directiva 2000/78/CE do Conselho, de 27 de novembro de 2000, que estabelece um quadro geral de igualdade de tratamento no emprego e na actividade profissional. Disponível em: <http://eur-lex.europa.eu/LexUriServ/ LexUriServ.do?uri=CELEX:32000L0078:pt:HTML>. Acesso em: 5 dez. 2012.

UNIÃO EUROPEIA. Directiva 76/207/CEE do Conselho, de 9 de fevereiro de 1976, relativa à concretização do princípio da igualdade de tratamento entre homens $e$ mulheres no que se refere ao acesso ao emprego, à formação e promoção profissionais e às condições de trabalho. Disponível em: <http://eur-lex.europa.eu/ LexUriServ/LexUriServ.do?uri=CELEX:31976L0207:PT:HTML>. Acesso em: 4 dez. 2012.

UNIÃO EUROPEIA. Directiva 86/613/CEE do Conselho, de 11 de dezembro de 1986 relativa à aplicação do princípio da igualdade de tratamento entre homens e mulheres que exerçam uma actividade independente incluindo a actividade agrícola, bem como à protecção da maternidade. Disponível em: <http://eur-lex.europa.eu/ lexuriserv/lexuriserv.do?uri=celex:3198610613:pt:html>. Acesso em: 4 dez. 2012.

UNIÃO EUROPEIA. Informações gerais sobre a União Europeia. Disponível em: <http://europa.eu/about-eu/basic-information/index_pt.htm>. Acesso em: 4 dez. 2012.

UNIÃO EUROPEIA. Jornal Oficial da União Europeia, ano 53, n. C83, 30 mar. 2010. Disponível em: <http://eur-lex.europa.eu/LexUriServ/LexUriServ.do?uri=OJ:C:2010:083: FULL:PT:PDF>. acesso em: 5 dez. 2012.

UNIÃO EUROPEIA. Recomendação 86/379/CEE do Conselho, de 24 de julho de 1986 sobre o emprego de deficientes na Comunidade. Disponível em: <http://eurlex.europa.eu/LexUriServ/LexUriServ.do?uri=CELEX:31986h0379:PT:HTML>. Acesso em: 5 dez. 2012.

UNIÃO EUROPEIA. Resolução do Conselho da União Europeia e dos Representantes dos Governos dos Estados-Membros, reunidos no Conselho de 17 de março de 2008 sobre a situação das pessoas com deficiência na União Europeia. Disponível em: <http://eur-lex.europa.eu/LexUriServ/LexUriServ.do?uri=CELEX:42008x0326(01):PT:

HTML>. Acesso em: 5 dez. 2012. 
UNIÃO EUROPEIA. Resolução do Conselho de 15 de julho de 2003 relativa à promoção do emprego e da integração social das pessoas com deficiência. Disponível em: <http://eur-lex.europa.eu/LexUriServ/LexUriServ.do?uri=CELEX:32003G0724(01): PT:HTML>. Acesso em: 5 dez. 2012.

UNIÃO EUROPEIA. Resolução do Conselho de 17 de junho de 1999 sobre a igualdade de oportunidades de emprego para pessoas com deficiência. Disponível em: <http://ec.europa.eu/employment_social/soc-prot/disable/ojc186/councilres_pt.pdf>.

Acesso em: 5 dez. 2012.

UNIÃO EUROPEIA. Resolução do Conselho de 5 de maio de 2003 relativa à igualdade de oportunidades em matéria de educação e formação de alunos e estudantes com deficiência. Disponível em: <http://eur-lex.europa.eu/LexUriServ/LexUriServ.do? uri=OJ:C:2003:134:0006:0007:PT:PDF>. Acesso em: 5 dez. 2012.

UNIÃO EUROPEIA. Resolução do Conselho de 6 de maio de 2003, sobre o acesso das pessoas com deficiência às infraestruturas e actividades culturais. Disponível em: <http://eur-lex.europa.eu/LexUriServ/LexUriServ.do?uri=CELEX:32003G0607(02):PT:

HTML>. Acesso em: 5 dez. 2012.

UNIÃO EUROPEIA. Resolução do Conselho e dos Ministros da Educação Reunidos em Conselho em 31 de maio de 1990 relativa à integração das crianças e dos jovens deficientes no sistema de ensino regular. Disponível em: <http://eur-lex.europa.eu/ LexUriServ/LexUriServ.do?uri=OJ:C:1990:162:0002:0003:PT:PDF $>$. Acesso em: 5 dez. 2012.

UNIÃO EUROPEIA. Resolução do Conselho e dos representantes dos Governos dos Estados-Membros reunidos no Conselho de 20 de dezembro de 1996 sobre a igualdade de oportunidades para pessoas deficientes. Disponível em: <http://eurlex.europa.eu/LexUriServ/LexUriServ.do?uri=CELEX:41997X0113:PT:HTML>. Acesso em: 5 dez. 2012.

UNIÃO EUROPEIA. Resolução do Conselho, de 17 de junho de 1999, sobre a igualdade de oportunidades de emprego para pessoas com deficiência. Disponível em: <http://eur-lex.europa.eu/LexUriServ/LexUriServ.do?uri=CELEX:31999Y0702(01):PT: HTML>. Acesso em: 5 dez. 2012.

VARELLA, Drauzio. Lábio leporino, fenda palatina. Disponível em: <http://drauziovarella.com.br/doencas-e-sintomas/labio-leporinofenda-palatina>. Acesso em: 17 dez. 2012. 
VILLATORE, Marco Antonio César. O Decreto n. 3.298, de 20.12.99: a pessoa portadora de deficiência no direito do trabalho brasileiro e o tema no direito do trabalho comparado. Revista LTr. São Paulo, v. 64, n. 5, maio 2000. 